\title{
Sea lice (Copepoda, Siphonostomatoida, Caligidae) new to Korea, including three new species
}

\author{
Seong Yong Moon ${ }^{1,2}$ and Il-Hoi Kim ${ }^{1, *}$ \\ ${ }^{1}$ Department of Biology, Gangneung-Wonju National University, Gangneung 210-702, Korea \\ ${ }^{2}$ Division of Marine Technology, Chonnam National University, Yeosu 550-749, Korea \\ *Correspondent:ihkim@gwnu.ac.kr
}

\begin{abstract}
Thirteen species of sea lice (Copepoda, Caligidae) are described as parasites of marine fishes from Korea including three new species such as Pseudocaligus longipes n. sp. from Siganus fuscesens (Houttuyn), Lepeophtheirus tamladus n. sp. from Sebastes inermis Cuvier, and Lepeophtheirus gusevi n. sp. from Sebasetes schlegeli Hilgendorf. Remaining ten species are new to Korea: Caligus elongatus Nordmann, 1832; C. equulae Ho and Lin, 2003; C. fistulariae Yamaguti, 1936; C. laticaudus Shiino, 1960; C. rotundigenitalis Yü, 1933; Metacaligus uruguayensis (Thomsen, 1949); Lepeophtheirus atypicus Lin, Ho and Chen, 1996; L. parvulus Shiino, 1952; Anuretes quadrilaterus Shiino, 1954; and Pseudanuretes chaetodontis Yamaguti, 1936.
\end{abstract}

Keywords: caligidae, fish parasites, Korea, new record, new species, sea lice

\section{INTRODUCTION}

According to Kim(2008) there are twenty-five species of sea lice belonging to the family Caligidae have so far been recorded as parasites from the Korean waters, including 14 species of Caligus, 10 Lepeophtheirus, and 1 Pseudocaligus. Choe and Kim (2010) reported Caligus spinosus Yamaguti, 1939 and C. aesopus Wilson, 1921 parasitic on Seriola spp. Caligus undulatus Shen and Lin, 1959 was recorded from plankton sample in Korea(Venmathi Maran and Ohtsuka, 2008). Recently, Venmathi Maran et al. (2012) reported C. sclerotinosus from Pagrus major. Hence, in total 29 species of sea lice have so far been recorded from the Korean waters.

Recently, we could examine various marine fishes caught mainly from the coasts of Jeju Island to collect parasitic copepods. Among the collected copepods three species of sea lice are new to science and rest are new records to Korean fauna. This paper deals with the description of these 13 species, as follows:

Genus Caligus Müller, 1785

1. Caligus elongatus Nordmann, 1832

2. Caligus equulae Ho and Lin, 2003

3. Caligus fistulariae Yamaguti, 1936

4. Caligus laticaudus Shiino, 1960

5. Caligus rotundigenitalis Yü, 1933

Genus Pseudocaligus A. Scott, 1901

6. Pseudocaligus longipes $\mathrm{n}$. $\mathrm{sp}$.
Genus Metacaligus Thomsen, 1949

7. Metacaligus uruguayensis (Thomsen, 1949)

Genus Lepeophtheirus Nordmann, 1832

8. Lepeophtheirus atypicus Lin, Ho and Chen, 1996

9. Lepeophtheirus parvulus Shiino, 1952

10. Lepeophtheirus tamradus n. sp.

11. Lepeophtheirus gusevi $\mathrm{n} . \mathrm{sp}$.

Genus Anuretes Heller, 1865

12. Anuretes quadrilaterus Shiino, 1954

Genus Pseudanuretes Yamaguti, 1936

13. Pseudanuretes chaetodontis Yamaguti, 1936

\section{Materials And Methods}

The examined parasitic copepod specimens were collected from gills and skins of the marine fishes caught mainly from the coasts of Jeju Island. In the laboratory, marine fishes were examined and the parasites were removed and preserved in $80 \%$ ethanol. Dissection was done using the reversed slide method (Humes and Gooding, 1964). The drawings were made on the Olympus $\mathrm{BH}-2$ microscope using a drawing tube. In the formula for the armature of legs 1-4 Roman numerals indicate spines and Arabic numerals represent setae. Type specimens will be deposited in the National Institute of Biological Resources (NIBR), Incheon, Korea. 


\section{Systematic Accounts}

Family Caligidae Burmeister, 1835

Genus Caligus Müller, 1785

\section{Caligus elongatus Nordmann, 1832}

(Figs. 1, 2)

Caligus elongatus Nordmann, 1832, p. 24; Parker, 1969, p. 1014, figs. 1-4; Hewitt, 1971, p. 163, figs. 73-78; Kabata, 1979, p. 179, figs. 549-558.

Material examined. 2 우 우, from the skin of Lepidotrigla sp., Samcheonpo, in the southern coast of Korea, I.H. Kim, 20 October 2011.

Female. Body (Fig. 1A) $5.62 \mathrm{~mm}$ long. Cephalothoracic shield subcircular, $3.23 \times 2.88 \mathrm{~mm}$. Lateral zone with thin, slightly undulated ventral rib; shallow posterolateral pit present on dorsal surface. Thoracic zone extending beyond posterior end of lateral zone. Fourth pedigerous somite incompletely divided from genital complex. Genital complex subcircular, $1.50 \times 1.73 \mathrm{~mm}$, wider than long. Abdomen (Fig. 1B) rather well defined from genital complex, $577 \times 615 \mu \mathrm{m}$, and proximally narrowed. Caudal ramus $208 \times 200 \mu \mathrm{m}$, with 6 setae.

Antennule (Fig. 1C) 2-segmented; proximal segment $406 \mu \mathrm{m}$ long, with 27 pinnate and 2 naked setae; distal segment $252 \mu \mathrm{m}$ long, with 11 naked setae and 2 aesthetascs. Antenna (Fig. 1D) 3-segmented; first segment with slender, tapering proximal process; second segment nearly quadrangular, with 1 dorsal adhesion pad; third segment forming large, distally strongly bent claw bearing 2 setae. Postantennal process (Fig. 1E) bearing 2 papillae each tipped with 2 or 4 setules; another papilla located posterior to postantennal process, bearing 4 setules.

Mandible (Fig. 1F) with 12 teeth distally. Maxillule (Fig. 1G) consisting of anterior papilla bearing 3 unequal setae and posterior process bearing 1 simple tine. Maxilla (Fig. 1H) 2-segmented; proximal segment (lacertus) unarmed; distal segment (brachium) with small membrane (flabellum) in distal 1/3 of margin; calamus less than twice as long as canna. Maxilliped (Fig. 1I) 3-segmented; first segment (corpus) unarmed but with 1 small, indistinct process on medial (myxal) margin; second segment (shaft) with 1 vestigial subdistal seta; third segment forming large, sharp claw bearing 1 seta at base. Sternal furca (Fig. 1J) narrow, with tapering, slightly divergernt tines bearing narrow lateral flanges and pointed tip.

Armature on rami of legs 1-4 as follows:

Leg 1: exopod 1-0; III,1,3; endopod (vestigial)

Leg 2: exopod I-1; I-1; II,I,5; endopod 0-1; 0-2; 6

Leg 3: exopod I-1; I-1; III,4; endopod 0-1; 6

Leg 4: exopod I-0; I-0; III; endopod (lacking)
Leg 1 (Fig. 2A) coxa with branched small outer setule; basis with pinnate outer and inner setae. Proximal exopodal segment slightly bullate, with 1 small outer distal naked seta and row of setules on inner margin; 3 distal spines of distal segment 77,68 , and $38 \mu \mathrm{m}$, respectively, from outer (anterior) to inner, second and third spines bifurcate; innermost distal seta (seta IV) much longer than distal spines, weakly pinnate along outer margin but flanged with membrane along inner margin (Fig. 2B). Leg 2 (Fig. 2C) coxa with large seta on inner posterior margin and setule on ventral surface; basis with small outer seta and 1 inner setule and membrane on inner part of posterior margin. Leg 3 (Fig. 2D) exopod with first segment bearing large outer spine. Leg 4 (Fig. 2E) protopod slightly bullate in middle, with small outer distal seta. Exopod 2-segmented; proximal segment with 1 distal seta ( $83 \mu \mathrm{m}$ long); distal segment longer than proximal segment, with 1 spine $(77 \mu \mathrm{m})$ on outer margin and 3 spines on distal margin $(78,114,325 \mu \mathrm{m}$, respectively, from outer to inner; all spines on exopodal segments accompanied with flabelliform membrane at base. Leg 5 represented by small papilla tipped by 1 seta and another neaby papilla bearing 2 setae on posterior margin of genital complex.

Male. Unknown in Korea.

Distribution and hosts. Most regions of the world's oceans; parasitic on more than 80 species of fish (Kabata, 1979).

Remarks. Major morphological characters of the present specimens, such as the exopod of leg 4 which is 2-segmented, with the armatures of 1 and 4 spines respectively on the proximal and distal segments, with the innermost distal spine of them being more than twice as long as nearby spine and the innermost terminal seta (fourth element) on the distal exopodal segment of leg 4 has a membrane along the inner margin, belong to $C$. elongatus. However, there are some characters in our specimens deviate from previous descriptions of C. elongatus (Parker, 1969; Kabata, 1979): the abdomen is not distinctly longer than its width; the tines of sternal furca bears lateral flanges; the third distal spine of the distal exopodal segment of leg 1 is distinctly smaller than the second spine. We consider these differences to be less important than the former major similarities. Although C. elongatus has been recorded from most part of the world (Parker, 1969; Kabata, 1979), it has so far not been reported from the Far Eastern region.

\section{Caligus equulae Ho and Lin, 2003}

(Figs. 3, 4)

Caligus equulae Ho and Lin, 2003a, p. 59, figs. 3-5; Ho and Lin, 2004, p. 179, figs. 93-95.

Material examined. $1 \sigma^{7}$ from the skin of Carangoides 

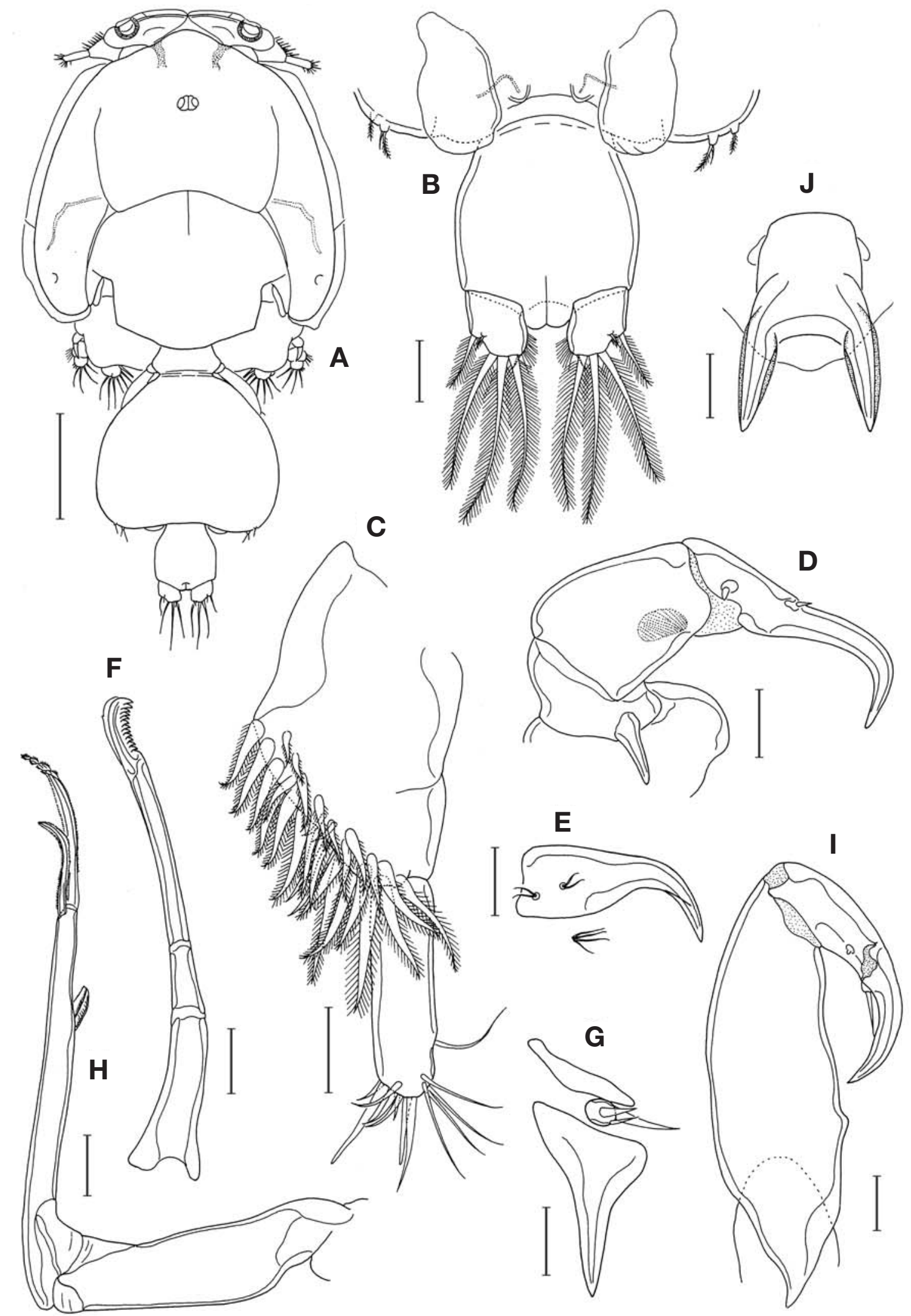

Fig. 1. Caligus elongatus Nordmann, female. A. habitus, dorsal. B. abdomen, ventral. C. antennule. D. antenna. E. postantennary process. F. mandible. G. maxillule. H. maxilla. I. maxilliped. J. sternal furca. Scales=A. $1 \mathrm{~mm}$. B. $0.2 \mathrm{~mm}$. C-J. $0.1 \mathrm{~mm}$. 

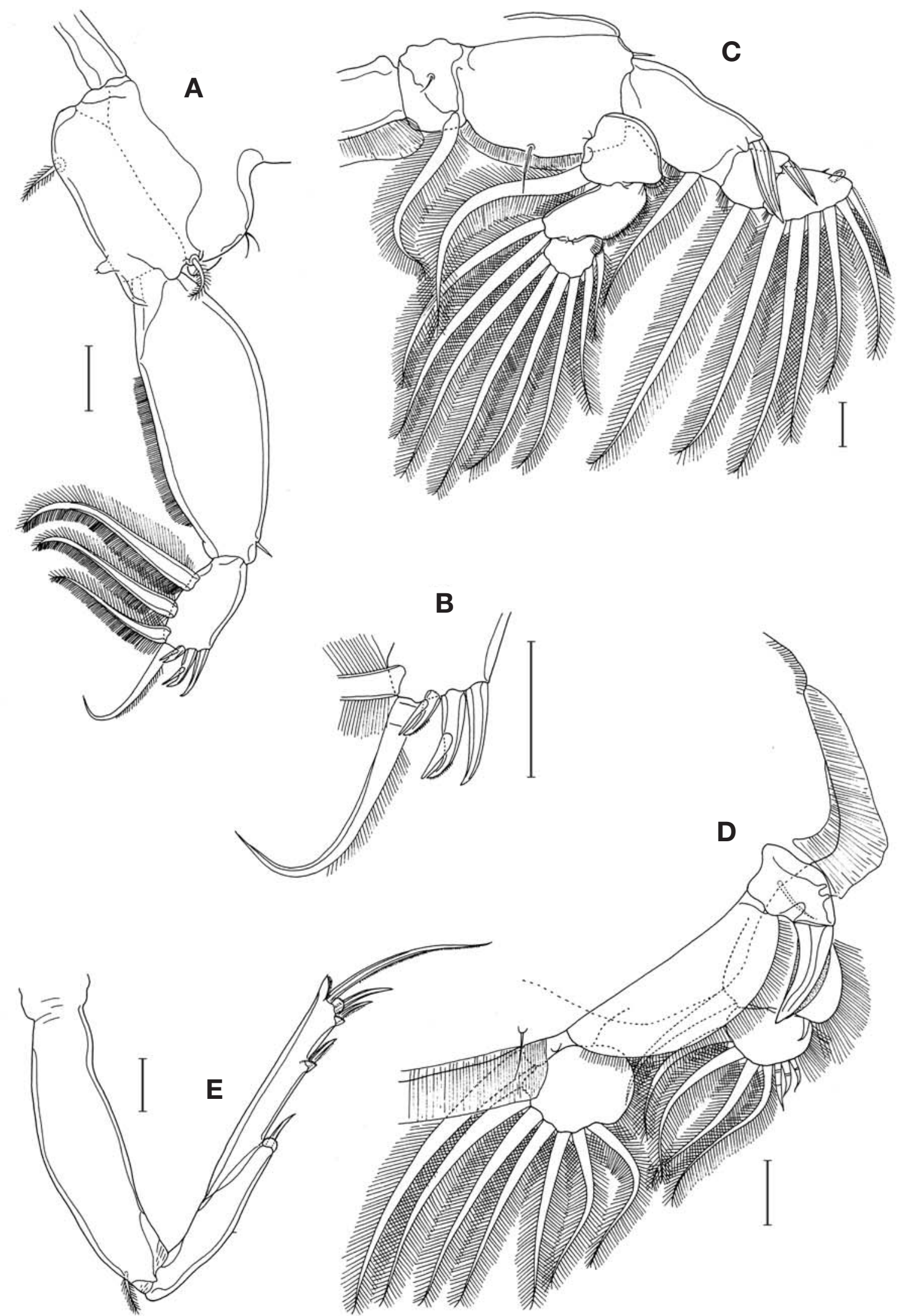

Fig. 2. Caligus elongatus Nordmann, female. A. leg 1. B. distal part of exopod of leg 1. C. leg 2. D. leg 3. E. leg 4. Scales=0.1 mm for all. 


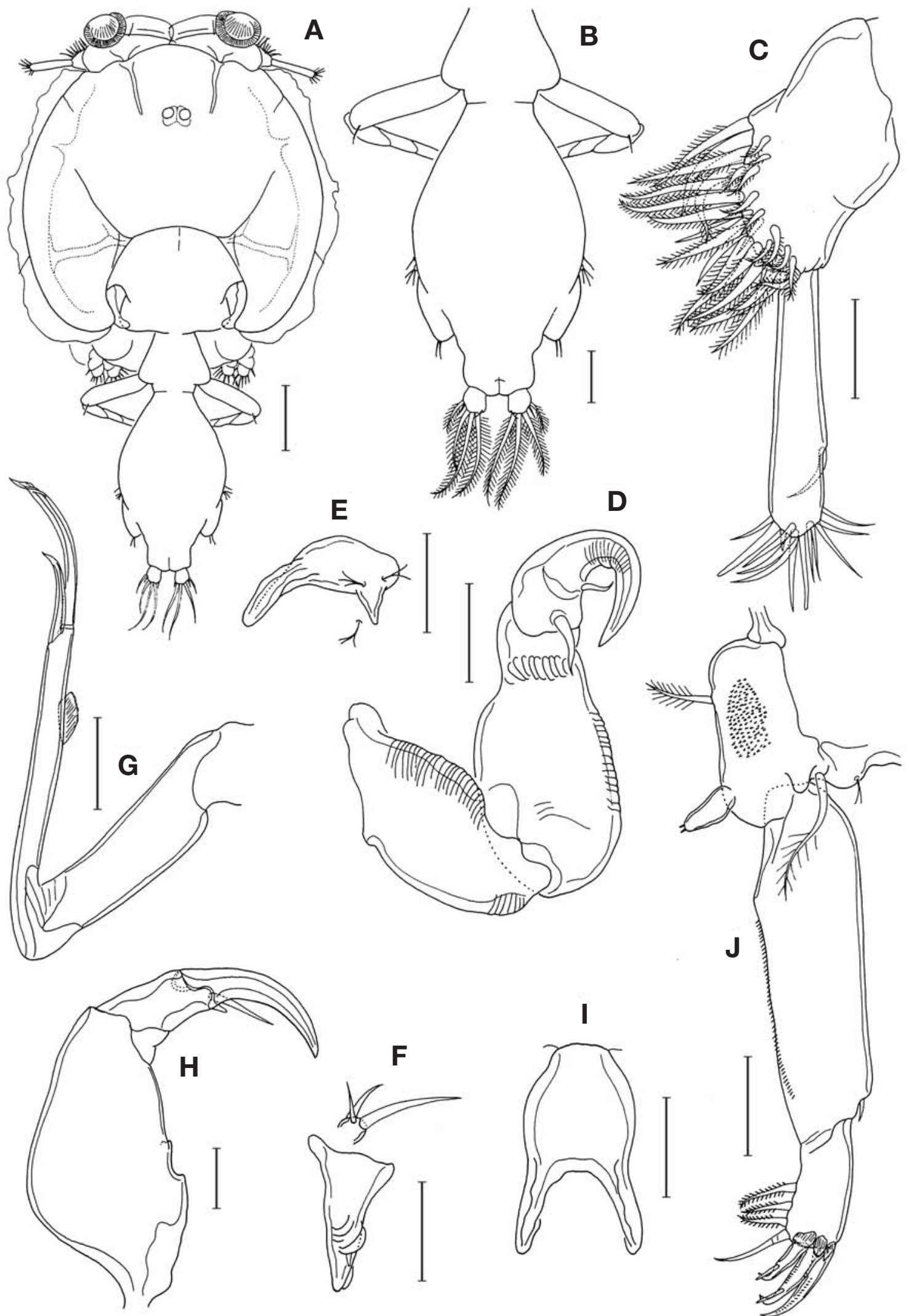

Fig. 3. Caligus equulae Nordmann, female. A. habitus, dorsal. B. urosome, dorsal. C. antennule. D. antenna. E. postantennal process. F. maxillule. G. maxilla. H. maxilliped. I. sternal furca. J. leg 1. Scales=A. $0.2 \mathrm{~mm}$. B. $0.1 \mathrm{~mm}$. C-J. $0.05 \mathrm{~mm}$. 


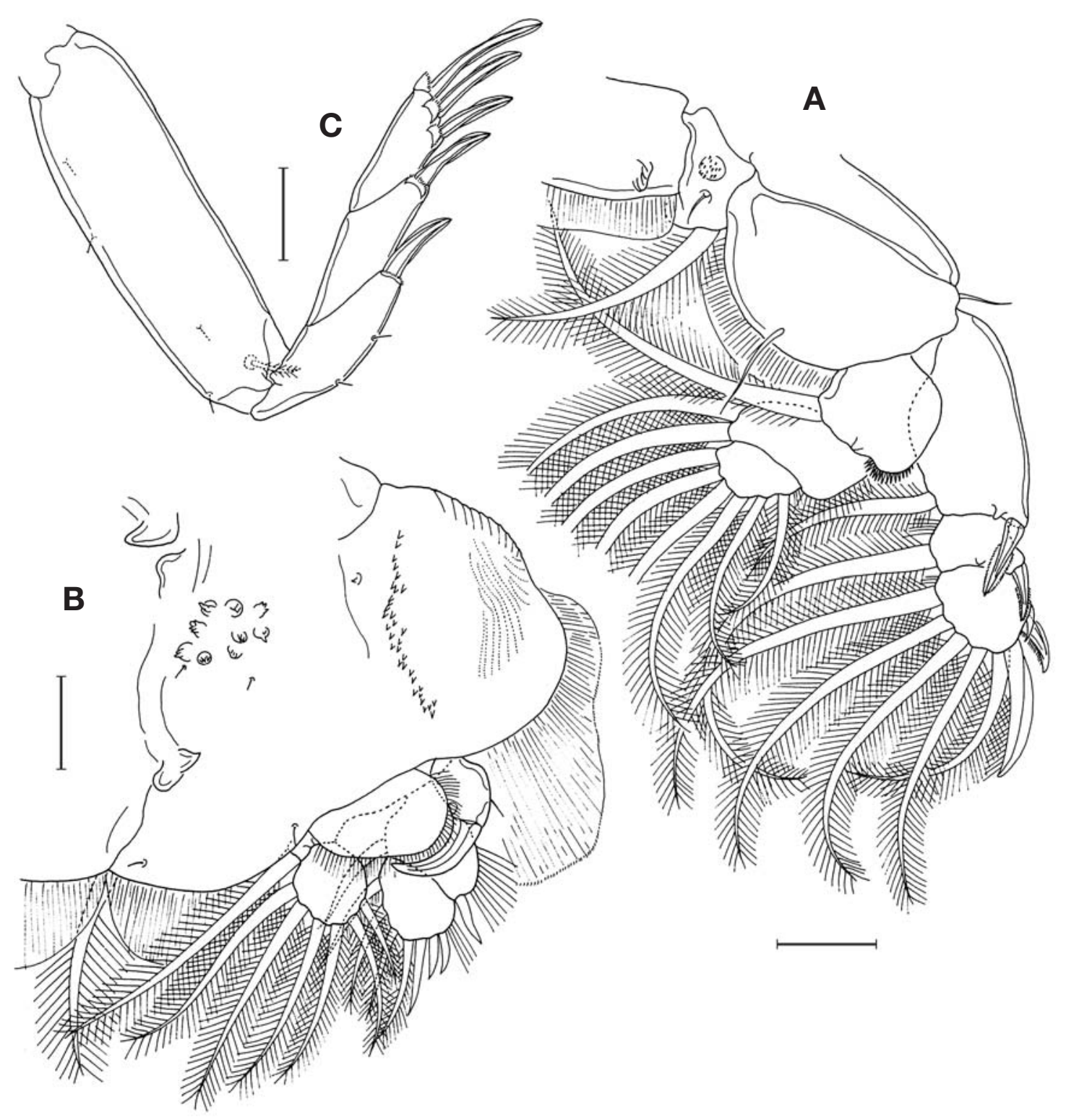

Fig. 4. Caligus equulae Nordmann, female. A. leg 2. B. leg 3. C. leg 4. Scales $=0.05 \mathrm{~mm}$ for all.

equula (Temminck and Schelegel), Jeonchon Port, Gampo-eup, Gyeongju-shi, in the eastern coast of Korea, S. Y. Moon, 2 February 2010.

Male. Body (Fig. 3A) $1.80 \mathrm{~mm}$ long. Cephalothoracic shield circular, $1.01 \times 0.95 \mathrm{~mm}$; lateral zone with T-shaped ventral rib, without posterolateral pit; posterior sinus deep. Genital complex fused with abdomen to form fusiform genitoabdomen (Fig. 3B) of $567 \times 333 \mu \mathrm{m}$. Fourth pedigerous somite incompletely articulated from genitoabdomen. Caudal ramus $46 \times 45 \mu \mathrm{m}$, almost as long as wide, with 4 pinnate and 2 small naked setae.

Antennule (Fig. 3C) 2-segmented; proximal segment about $132 \mu \mathrm{m}$ long, with 27 pinnate and 2 naked setae; distal segment elongated, $135 \mu \mathrm{m}$ long, slightly longer than proximal segment, with 12 naked setae and 2 aesthetascs. Antenna (Fig. 3D) 3-segmented; first segment with 2 adhesion pads; second segment narrowed distally, with subdistal and lateral adhesion pads; third segment forming strongly curved claw bearing 2 proximal setae. Postantennal process (Fig. 3E) proximally bearing 1 small posterior subsidiary process and 2 papillae each tipped with 2 or 3 setules; distal claw of postantennal process blunt and uneven; another papilla located posterior to postantennal process tipped with 3 setules.

Mandible with 12 teeth distally. Maxillule (Fig. 3F) consisting of anterior papilla bearing 3 unequal setae and posterior process bearing abhesion pad and 1 small seta. Maxilla (Fig. 3G) 2-segmented; proximal segment unar- 
med; slender distal segment with membrane (flabellum) at about $2 / 3$ region of segment; calamus about twice as long as canna. Maxilliped (Fig. 3H) 3-segmented; first segment (corpus) robust, with strongly convex outer margin and 2 small processes on inner margin; second segment (shaft) short, distally with 1 seta and 1 small, digitiform seta; third segment as evenly curved claw. Sternal furca (Fig. 3I) with narrow, rather divergent tines.

Armature on rami of legs 1-4 as follows:

Leg 1: exopod 1-0; III,1,3; endopod (vestigial)

Leg 2: exopod I-1; I-1; II,I,5; endopod 0-1; 0-2; 6

Leg 3: exopod I-0; I-1; III,4; endopod 0-1; 6

Leg 4: exopod I-0; I-0; III; endopod (lacking)

Leg 1 (Fig. 3J) coxa with branched outer setule; basis with weakly pinnate outer seta, smaller pinnate inner seta, and patch of numerous minute spinules on ventral surface. Proximal exopodal segment with 1 small outer distal naked seta and row of spinules on inner margin; distal segment with three distal spines each accompanied by flabelliform membrane; two inner distal spines bifurcating at about their distal third; distal seta naked; endopod digitiform and tipped with 2 small processes. Leg 2 (Fig. 4A) coxa with large seta on inner posterior margin, 1 patch of minute spinules and 1 setule on ventral surface; basis with small outer seta and 1 inner setule and membrane on inner part of posterior margin; first endopodal with spinules on distal part of outer margin; outer side of basis and first exopodal segment with broad membrane (not illustrated in Fig. 4A). Leg 3 (Fig. 4B) protopod (apron) with longitudinally elongate patch of spinules on mid-ventral surface and several flexible, irregular, papillae on inner ventral surface; spine on first exopodal segment enlarged and strongly curved. Leg 4 (Fig. 4C) protopod moderately expanded, with small outer distal seta and 4 small setules on outer side; exopodal segments similar in length; spines on these segments similar in shape, all with membrane on both sides. Leg 5 represented by 1 and 3 small setae on lateral side of genitoabdomen. Leg 6 represented by 2 smalle setae on genital flap (Fig. 3B).

Female. Unknown in Korea.

Distribution and host. Known only from Carangoides eauula (Temminck and Schlegel) in Taiwan (Ho and Lin, 2003a) and Korea (the present record).

Remarks. A single male specimen found in the present study agrees well with the original description by Ho and Lin (2003). The main characters shared by the specimens from both Taiwan and Korea are the possession of the small body size, the fusiform genitoabdomen, the small caudal rami, the elongate distal segment of the antennule, the simple terminal claw of the antenna, and the 3 small pinnate setae on the posterior (medial) margin of the distal exopodal segment of leg 1 .

\section{Caligus fistulariae Yamaguti, 1936}

(Figs. 5, 6)

Caligus fistulariae Yamaguti, 1936, p. 3, pl. 2, figs. 1426; Shiino, 1964, p. 243, figs. 1, 2; Fernández and Villalba, 1986, p. 45; Ho et al., 2008, p. 88, figs. 1-3.

Material examined. 2 우 우, $1 \sigma^{7}$ from mouth tube of Fistularia commersonii Ruppell, at Sagye in Jeju Island, M.-K. Choe, 29 October 2009.

Female. Body (Fig. 5A) large, 6.86 mm long. Cephalothoracic shield $3.13 \times 2.44 \mathrm{~mm}$, distinctly longer than wide; lateral zone with smoothly curved ventral rib; posterior sinus deep; posterolateral pit present. Fourth pedigerous somite indistinctly articulated from genital complex. Genital complex gradually broadened distally, 2.30 $\times 1.92 \mathrm{~mm}$, with rounded and slightly projected posterolateral corners. Abdomen 1-segmented, $0.90 \times 0.67 \mathrm{~mm}$, with convex lateral margins. Caudal ramus $335 \times 219$ $\mu \mathrm{m}, 1.53$ times as long as wide, with 6 setae; inner margin convex, with setules on distal half (Fig. 5B).

Antennule (Fig. 5C) $558 \mu \mathrm{m}$ long and 2-segmented; proximal segment occupying $65 \%$ length of antennule, with 27 pinnate and 2 naked setae; distal segment with 12 naked setae and 2 aesthetascs. Antenna 3-segmented; first segment without proximal process (Fig. 5D); second segment nearly quadrangular, with 1 adhesion pad; third segment forming long, distally strongly bent claw bearing 2 small setae. Postantennal process proximally bearing 2 papillae each tipped with 1 setule; another papilla located posterior to postantennal process also tipped with 1 setule.

Mandible with 12 teeth distally. Maxillule consisting of anterior papilla bearing 3 unequal setae and tapering posterior process (Fig. 5D). Maxilla (Fig. 5E) 2-segmented; proximal segment (lacertus) unarmed; slender distal segment (brachium) with membrane (flabellum) at about $70 \%$ region of inner margin; calamus about twice as long as canna. Maxilliped (Fig. 5F) 3-segmented; first segment (corpus) with broader proximal half and narrower distal half; second segment (shaft) 1 seta and 1 small denticle distally; third segment forming short, curved claw. Sternal furca (Fig. 5G) with slender, tapering tines bearing blunt tip.

Armature on rami of legs 1-4 as follows:

Leg 1: exopod 1-0; 3,1,3; endopod (vestigial)

Leg 2: exopod I-1; I-1; II,I,5; endopod 0-1; 0-2; 6

Leg 3: exopod I-0; I-1; III,4; endopod 0-1; 6

Leg 4: exopod I-0; III; endopod (lacking)

Leg 1 (Fig. 5H) coxa with simple outer setule; basis with pinnate outer and inner setae. Proximal exopodal segment with 1 small outer distal naked seta and row of setules on inner margin; distal segment with relatively short outermost seta; two mid-terminal setae with short setules; inner distal seta naked and longer than mid-ter- 

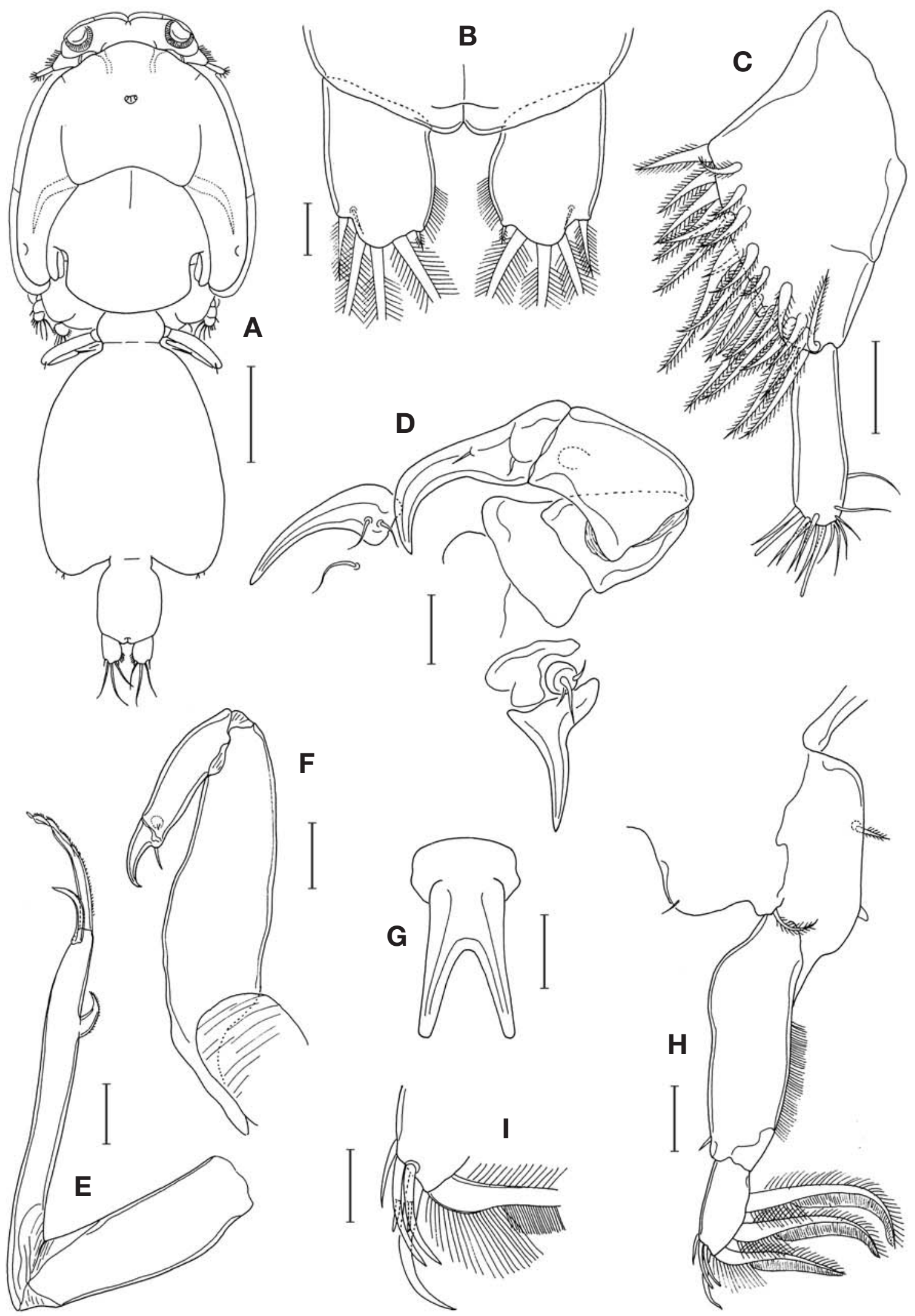

Fig. 5. Caligus fistulariae Yamaguti, female. A. habitus, dorsal. B. caudal rami, dorsal. C. antennule. D. antenna, postantennal process, and maxillule. E. maxilla. F. maxilliped. G. sternal furca. H. leg 1. I. distal part of leg 1. Scales=A. $1 \mathrm{~mm}$. B-H. $0.1 \mathrm{~mm}$. I. $0.05 \mathrm{~mm}$. 


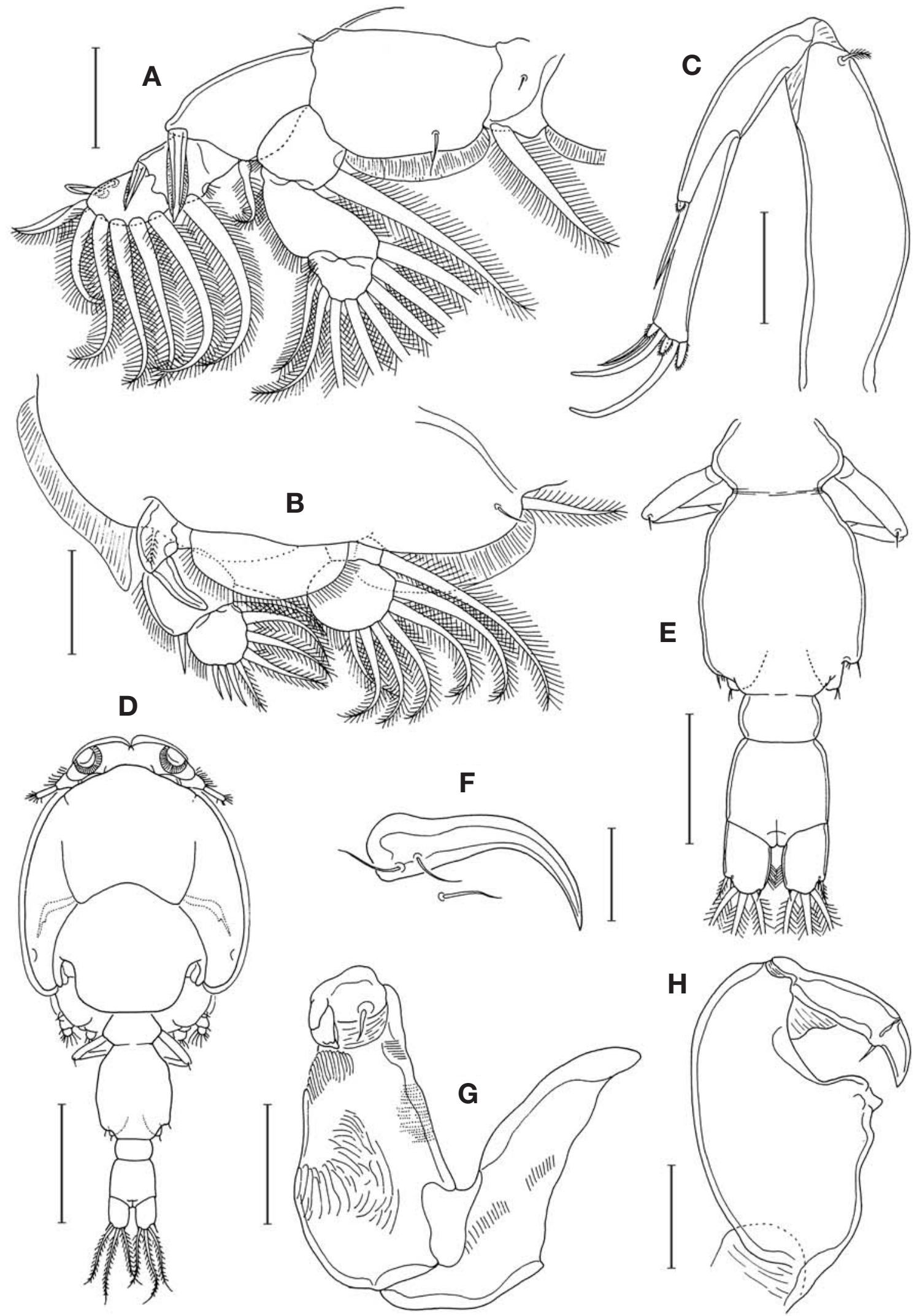

Fig. 6. Caligus fistulariae Yamaguti, female. A. leg 2. B. leg 2. C. leg 4. Male. D. habitus, dorsal. E. urosome, dorsal. F. postantennal process. G. antenna. H. maxilliped. Scales=A-C, H. $0.2 \mathrm{~mm}$. D. $1 \mathrm{~mm}$. E. $0.5 \mathrm{~mm}$. F, G. $0.1 \mathrm{~mm}$. 
minal setae; endopod small, knob-like. Leg 2 (Fig. 6A) coxa with large seta on inner posterior margin; basis with small outer seta and 1 inner setule and membrane on inner part of posterior margin; outer side of basis and first exopodal segment with broad membrane (not illustrated in Fig. 6A). Leg 3 (Fig. 6B) protopod broad membrane on outer and inner margins; outer spines on second and third segments setiform. Leg 4 (Fig. 6C) protopod with convex outer margin; spines on first exopodal segment $166 \mu \mathrm{m}$; three spines on terminal segment 131, 188, and $246 \mu \mathrm{m}$ from outer to inner; all spines on exopodal segments accompanied with flabella near base. Leg 5 represented by 1 and 2 small setae on posterolateral margin of genital complex.

Male. Body (Fig. 6D) $4.10 \mathrm{~mm}$ long. Cephalic shield resembling that of female, $2.29 \times 1.83 \mathrm{~mm}$. Genital complex $769 \times 638 \mu \mathrm{m}$. Abdomen 2-segmented; proximal segment $169 \times 315 \mu \mathrm{m}$; distal segment $323 \times 392 \mu \mathrm{m}$. Caudal ramus $269 \times 185 \mu \mathrm{m}$.

Antennule as in female. Antenna (Fig. 6G) 3-segmented as in female; first segment with 2 weak adhesion pads; second segment with 4 adhesion pads; third segment blunt, with 1 inner proximal setae and forming foliaceous. Postantennal process (Fig. 6F) larger than that of female.

Mandible, maxillule, and maxilla as in female. Maxilliped (Fig. $6 \mathrm{H}$ ) with protruded inner margin of first segment; claw short, stout, almost fused with second segment. Sternal furca similar to that of female.

Legs $1-5$ as in female. Leg 6 represented by 2 small setae on each genital flap.

Distribution and hosts. Japan, Taiwan, Korea, and Chile. Known hosts are Fistularia petimba Lacepède, $F$. villosa Kluzinger, F. commersonii Ruppell, and Aulostomus chinensis (Linnaeus).

Remarks. The form and relative size of the four terminal elements of leg 1 exopod and the shape of the three apical spines of leg 4 show some differences between the illustrations of Ho et al. (2008) and our specimens, which are thought to be artifacts. The larger body size and the characteristic shape of the sternal furca and maxilliped are shared by specimens from both countries.

\section{Caligus laticaudus Shiino, 1960}

(Figs. 7, 8)

Caligus laticaudus Shiino, 1960, p. 482, figs. 5, 6; Pillai, 1961, p. 91, fig. 3; Lewis, 1968, p. 71, figs. 29, 30; Ho et al., 2000, p. 172, figs. 7-9; Ho and Lin, 2004, p. 194, figs. 101-103.

Material examined. 2 우 우, 2 ㄲㄲ from Evynnis japonica Tanaka, at Sagye in Jeju Island, M. K. Choe, 29 August 2009; 4 우우, 1 자 from Evynnis japonica, at Aeweol in Jeju Island, M.-K. Choe, 22 October 2009.
Female. Body (Fig. 7A) $3.35 \mathrm{~mm}$ long. Cephalothoracic shield bcircular, $1.67 \times 1.67 \mathrm{~mm}$; lunules relatively small; ventral rib of lateral zone bifucated distally; posterior sinus deep; posterolatyeral pit present. Fourth pedigerous somite, genital complex, and abdomen fused to form genitoabdomen. Region of Genital complex widest across distal two-thirds, wider than long, $706 \times 894 \mu \mathrm{m}$. Abdominal region $529 \times 424 \mu \mathrm{m}$, single-segmented but with rudimentary articulation line laterally near middle. Caudal ramus $158 \times 129 \mu \mathrm{m}, 1.22$ times as long as wide, with 6 setae; inner margin with setules.

Antennule (Fig. 7C) $317 \mu \mathrm{m}$ long and 2-segmented; proximal segment occupying $68 \%$ length of antennule, with 25 setae; distal segment with 12 naked setae and 2 aesthetascs. Antenna (Fig. 7D) 3-segmented; first segment lacking posterior process; second segment nearly quadrangular; third segment forming very long, weakly curved claw bearing 1 small seta proximally. Postantennal process small (Fig. 7D) proximally bearing 2 papillae each tipped with 2 or 3 setules; another papilla located posterior to postantennal process tipped with 4 setules.

Mandible with 12 teeth distally. Maxillule consisting of anterior papilla bearing 3 small setae and posterior process bearing elongate distal tine. Maxilla (Fig. 8A) 2segmented and rather broad; proximal segment (lacertus) unarmed; distal segment (brachium) with membrane (flabellum) at about $60 \%$ region of inner margin; calamus about 1.4 times longer than canna. Maxilliped (Fig. 7E) 3segmented; first segment (corpus) characteristically with large, tapering, inner proximal process; second segment (shaft) short, with 1 distal seta; third segment almost fused with second, forming strong claw. Sternal furca (Fig. 7F) with moderately slender, slightly divergent tines bearing blunt tip.

Armature on rami of legs 1-4 as follows:

Leg 1: exopod 1-0; 3,1,3; endopod (vestigial)

Leg 2: exopod I-1; I-1; II,I,5; endopod 0-1; 0-2; 6

Leg 3: exopod I-0; I-1; III,4; endopod 0-1; 6

Leg 4: exopod I-0; I-0; III; endopod (lacking)

Leg 1 (Fig. 7G) coxa with branched outer setule; basis with pinnate outer and inner setae; proximal exopodal segment with 1 small outer distal naked seta and row of setules on inner margin; distal segment with 4 naked distal setae and 3 inner pinnate setae; outermost distal seta much smaller than other distal setae; all of these 4 distal setae without setule (or not branched); endopod rudimentary, its tip slightly recurved and pointed. Leg 2 (Fig. 7H) coxa with large seta on inner posterior margin; basis with small outer seta and 1 inner setule and membrane on inner part of posterior margin; second and third endopodal segments with patch of numerous minute spinules on outer surface. Leg 3 (Fig. 8B) protopod (apron) with several spinules on outer ventral surface; second exopodal 

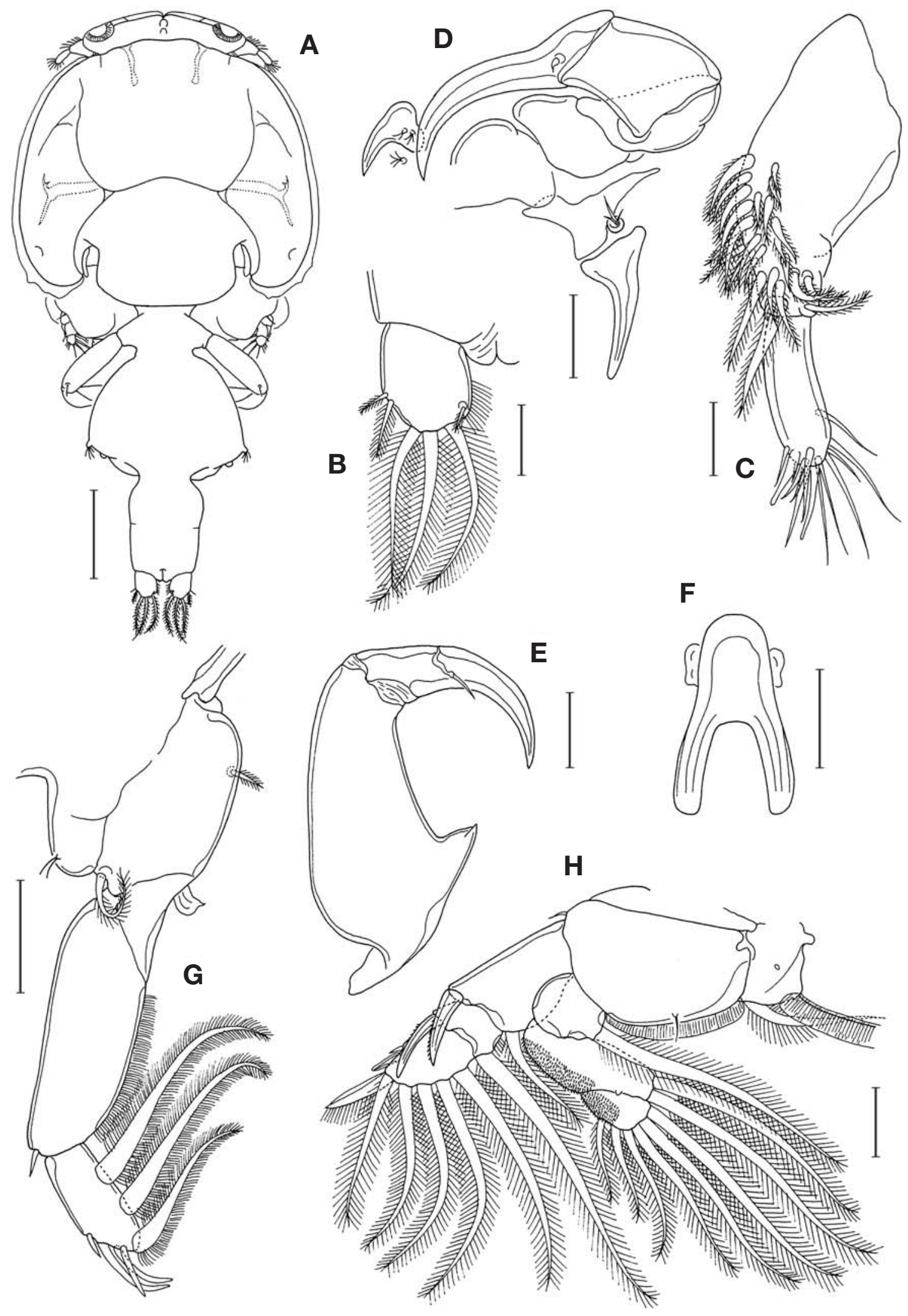

Fig. 7. Caligus laticaudus Shiino, female. A. habitus, dorsal. B. caudal ramus, dorsal. C. antennule. D. antenna, postantennal process, and maxillule. E. antenna. F. sternal furca. G. leg 1. H. leg 2. Scales=A. $0.5 \mathrm{~mm}$. B, D-H. $0.1 \mathrm{~mm}$. C. $0.05 \mathrm{~mm}$. 

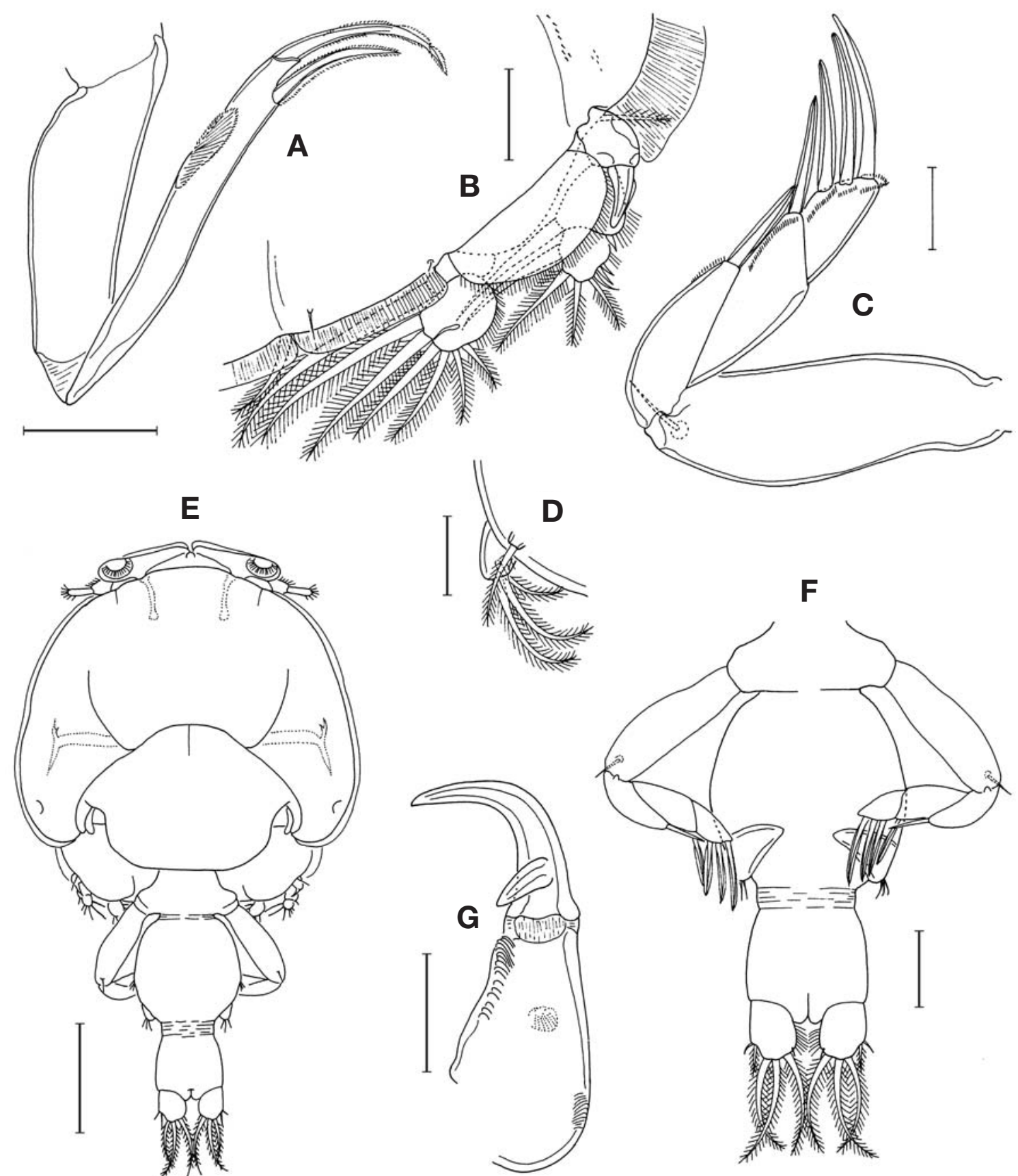

Fig. 8. Caligus laticaudus Shiino, female. A. maxilla. B. leg 3. C. leg 4. D. leg 5. Male. E. habitus, dorsal. F. urosome, ventral. G. second and third segments of antenna. Scales=A-C, G. $0.1 \mathrm{~mm}$. D. $0.05 \mathrm{~mm}$. E. $0.5 \mathrm{~mm}$. F. $0.2 \mathrm{~mm}$.

segment with vestigial articulation line dividing regions of proximal 2 and distal 4 setae. Leg 4 (Fig. 8C) rather broad, protopod with small outer distal seta; exopod 3segmented, with segments nearly similar in length; spines on first exopodal segment $135 \mu \mathrm{m}$; that of second segment $154 \mu \mathrm{m} ; 3$ spines on third segment 169, 192, and $213 \mu \mathrm{m}$, respectively, from outer to inner; exopodal segments with row of minute spinues near base of spines; spines of exopodal segments marginated with narrow membranes. Leg 5 (Fig. 8D) represented by 1 and 3 small setae on knob and 1 setae on papila at posterolateral margin of genital complex.

Male. Body (Fig. 8E) $2.66 \mathrm{~mm}$ long. Cephalic shield 1.49 $\times 1.54 \mathrm{~mm}$. Genital complex $523 \times 515 \mu \mathrm{m}$, with slightly convex lateral margins. Abdomen $300 \times 315 \mu \mathrm{m}$. Caudal ramus $153 \times 123 \mu \mathrm{m}, 1.24$ times as long as wide. 
Antennule not examined. Antenna 3-segmented; second segment with 3 adhesion pads; third segment forming large, strongly curved claw bearing 1 large subsidiary claw proximally (Fig. 8G). Postantennal process larger and longer than that of female.

Mandible, maxillule, maxilla, maxilliped and sternal furca not different from those of female. Legs 1-4 also as in female. Leg 5 represented by 3 small setae on genital flap (Fig. 8F). Leg 6 absent.

Distribution and hosts. Indo-West Pacific. From Acanthurus olivaceus Bloch and Schneider in Eniwetok Atoll (Lewis, 1968); Pagrus major (Temminck and Schlegel) in Japan (Shiino, 1960); Parapristipoma trilineatum (Risso) and Lutjanus vita (Quoy and Gaimard) in Taiwan (Ho et al., 2000); Polynemus heptadactylus Cuvier and Rhabdosargus sarba (Forskål) in India (Pillai, 1961); and Evynnis japonica Tanaka in Korea (present study).

Remarks. Ho et al. (2000) mentioned six distinguishing characteristics of Caligus laticaudus as follows: 1) the corpus (first segment) of the maxilliped has a large, conical protrusion on the medial surface; 2) the terminal element of the first exopod lack accessory processes; 3 ) element 1 of the four terminal armatures of leg 1 exopod is short, only about one third of the length of other three elements which are subequal in length; 4) the 3-segmented exopod of leg 4 with the armature of I-0, I-0, III; 5) the terminal three spines on the exopod of leg 4 are subequal in length; and 6) the 2-segmented abdomen is short and broad, with its length less than twice the width. The first five characteristics are easily confirmed in Korean specimens. In the last characteristics the segmentation of the abdomen is, however, not distinct, almost obsolete in Korean specimens.

\section{Caligus rotundigenitalis Yü, 1933}

(Figs. 9, 10)

Caligus rotundigenitalis Yü, 1933, p. 118, pl. 1, pl. 2, figs. 1-4; Rangnekar, 1959, p. 43, fig. 1a-m; Pillai and Natarajan, 1977, p. 55; Ho et al., 2000, p. 177; Ho and Lin, 2004, p. 268, figs. 3-14; Venmathi Maran et al., 2009; p. 797.

Caligus multispinosus: Lin et al., 1994, p. 259, figs. 5-7. Caligus seriolae Yamaguti, 1936, p. 2, pl. 1; Kim, 1998, p. 681 , figs. 324,325 .

Material examined. 3 우 우, $2 \sigma^{\top} \sigma^{\nearrow}$ from gills of Hapalogenys mucronatus (Eydoux and Souleyet), at Wando Island, in the southern coast of Korea, S. Y. Moon, 11 October 2009.

Female. Body (Fig. 9A) $2.63 \mathrm{~mm}$ long. Cephalothoracic shield circular, $1.24 \times 1.20 \mathrm{~mm}$; lunules small; ventral rib of lateral zone ramified distally; posterolateral pit present; posterior sinus moderately deep; thoracic zone extending far beyond lateral zone. Fourth pedigerous somite fused with genital complex. Urosome longer than prosome. Genital complex $568 \times 851 \mu \mathrm{m}$, wider than long, with rounded anterolateral and posterolateral corners. Abdomen fused with genital complex, $421 \times 254 \mu \mathrm{m}, 1$ segmented, its anterior half broader and posterior half narrower. Caudal rami slightly incurved, $112 \times 74 \mu \mathrm{m}$, 1.51 times as long as wide, with 6 setae, and setules on inner margin (Fig. 9B).

Antennule (Fig. 9C) $232 \mu \mathrm{m}$ long and 2-segmented; proximal segment occupying 64\% length of antennule, with 27 pinnate and 2 naked setae; distal segment with 12 naked setae and 2 aesthetascs. Antenna 3-segmented; first segment lacking proximal process (Fig. 9D); second segment nearly quadrangular; third segment forming large, distally bent claw bearing 2 small setae. Postantennal process small, bearing 2 papillae each tipped with 2 or 3 setules; another papilla located posterior to postantennal process tipped with 3 setules.

Mandible with 12 teeth. Maxillule consisting of anterior papilla bearing 3 setae and posterior elongate process bearing small denticle on side (Fig. 9D). Maxilla (Fig. 9E) 2-segmented; proximal segment (lacertus) slightly curved and unarmed; slender distal segment (brachium) with subdistal membrane (flabellum) at about $65 \%$ region of inner margin; calamus about about 1.3 times longer than canna. Maxilliped (Fig. 9F) 3-segmented; first segment (corpus) gradually narrowed distally; second segment (shaft) short, with 1 distal seta; third segment forming strongly curved claw. Sternal furca (Fig. 9G) with broad tines bearing blunt and oblique distal end.

Armature on rami of legs 1-4 as follows:

Leg 1: exopod 1-0; III,1,3; endopod (vestigial)

Leg 2: exopod I-1; I-1; II,I,5; endopod 0-1; 0-2; 6

Leg 3: exopod I-0; I-1; III,4; endopod 0-1; 6

Leg 4: exopod I-0; I-0; III; endopod (lacking)

Leg 1 (Fig. 9H) coxa with branched outer setule; basis with pinnate outer seta, smaller pinnate inner seta. Proximal exopodal segment with 1 small outer distal naked seta and row of setules on inner margin; outermost distal spine distinctly smaller than nearby elements and bearing spinules; other 3 distal element setiform, naked, and subequal in size, without setule or subsidiary element. Leg 2 (Fig. 10A) coxa with large seta on inner posterior margin; basis with small outer seta and 1 inner setule and membrane on inner part of posterior margin; second and third endopodal segments with patch of minute spinules on outer surface; outer side of basis and first exopodal segment with broad membrane (not illustrated in Fig. 10A). Leg 3 (Fig. 10B) protopod (apron) with broad membrane on outer and inner margins; outer spines of second and third exopodal segments setiform; outer proximal spine on third exopodal segment markedly smaller than distal 2 spines; distal endopodal segment with vestige of 

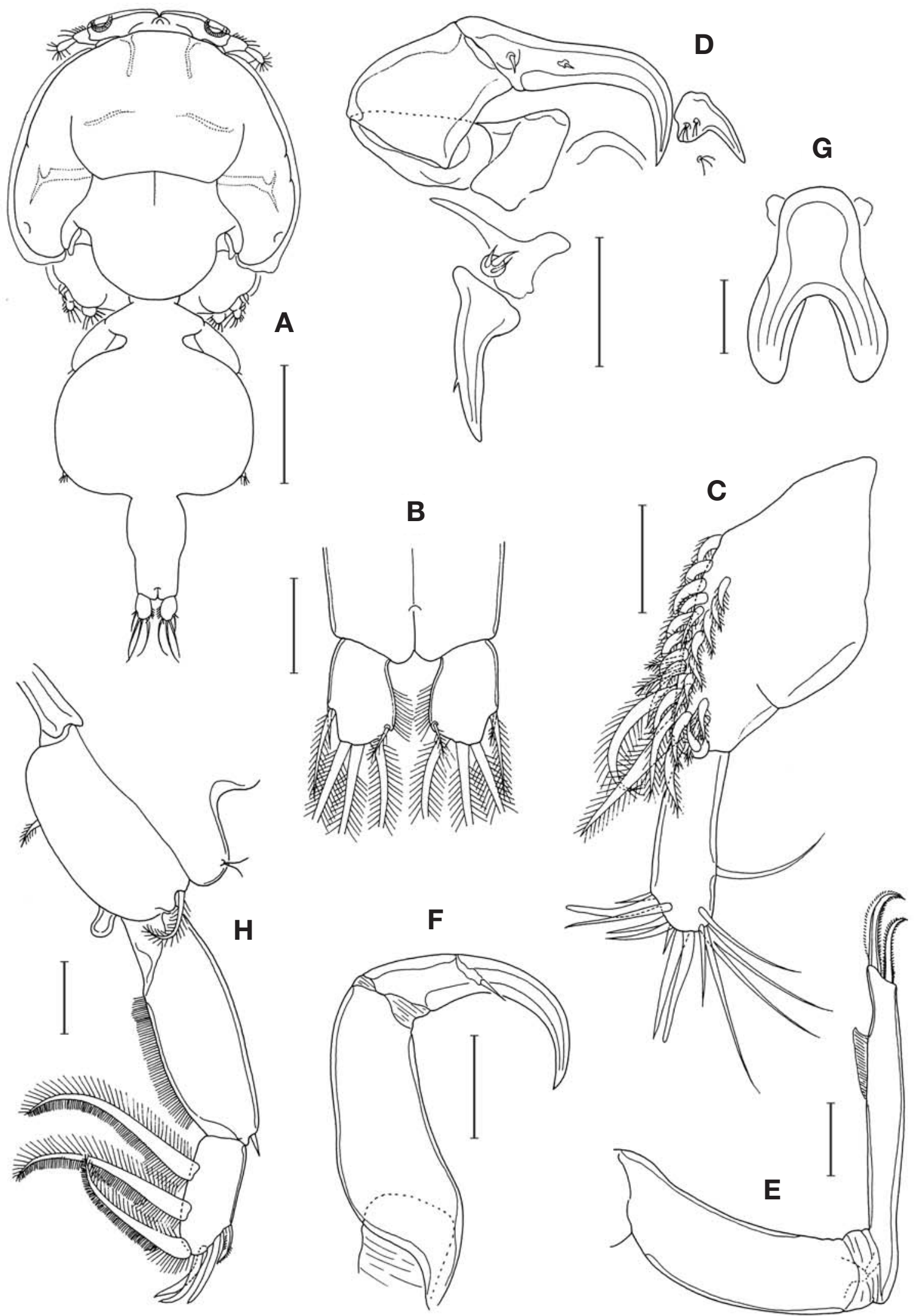

Fig. 9. Caligus rotundigenitalis Yü, female. A. habitus, dorsal. B. caudal rami, dorsal. C. antennule. D. antenna, postantennal process, and maxillule. E. maxilla. F. maxilliped. G. sternal furca. H. leg 1. Scales=A. $0.5 \mathrm{~mm}$. B, D, F. $0.1 \mathrm{~mm}$. C, E, G, H. $0.05 \mathrm{~mm}$. 

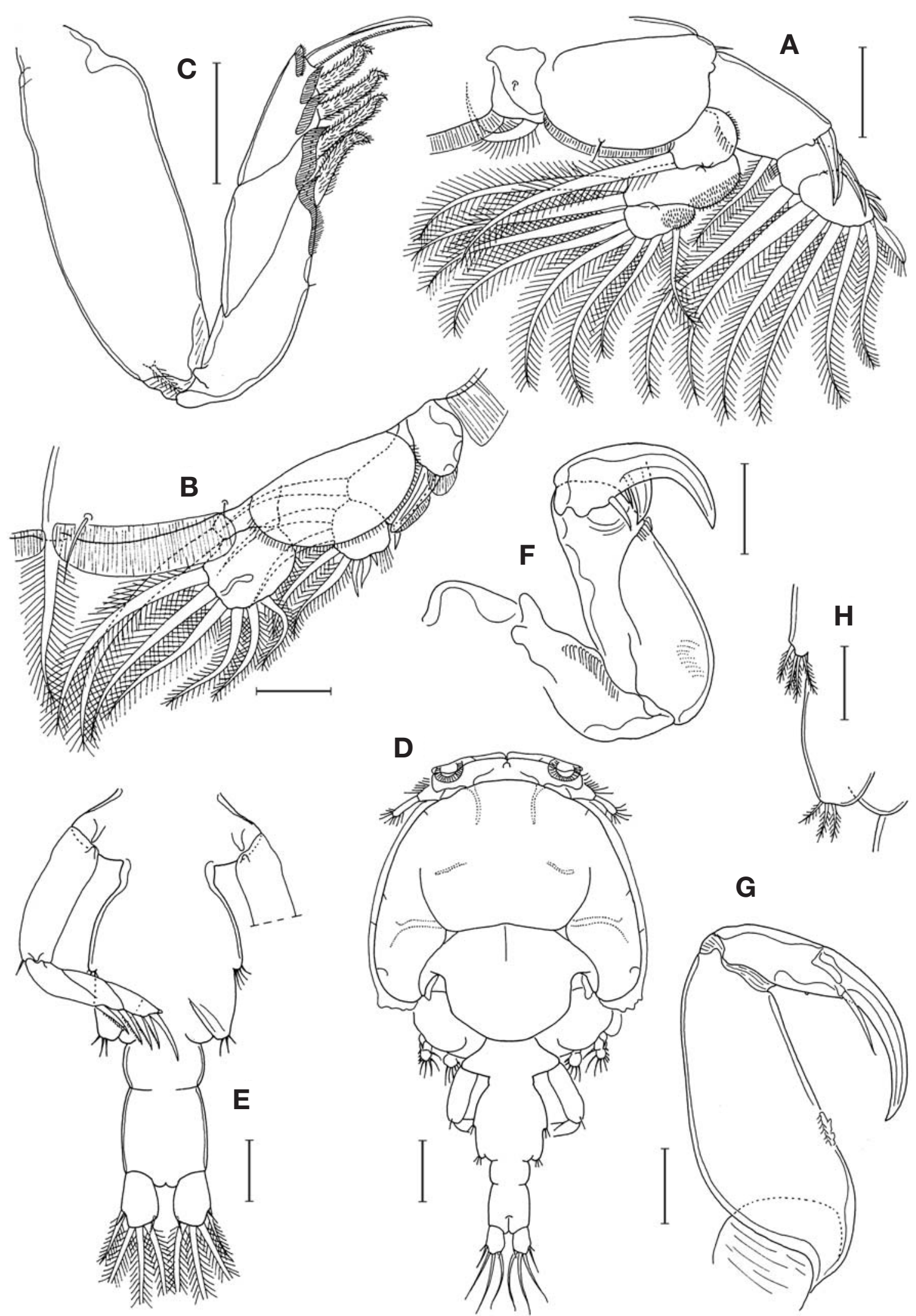

Fig. 10. Caligus rotundigenitalis Yü, female. A. leg 2. B. leg 3. C. leg 4. Male. D. habitus, dorsal. E. urosome, ventral. F. antenna. G. maxilliped. H. legs 5 and 6. Scales =A, C, E. $0.1 \mathrm{~mm}$. B, F-H. $0.05 \mathrm{~mm}$. D. $0.2 \mathrm{~mm}$. 
articulation. Leg 4(Fig. 10C) stocky; protopod with small outer distal seta. Exopod of leg 43 -segmented; first segment longest, with 1 small setule on outer margin; third segment tapering; distalmost spine on third segment 110 $\mu \mathrm{m}$ long, distinctly longer than other spines; other 4 spines on exopod setiform, dissimilar in form to distalmost spine, plumose, and distally curved; all spines on exopod accompanied by membrane near base. Leg 5 represented by 1 and 3 small setae on posterolateral margin of genital complex.

Male. Body (Fig. 10D) $1.61 \mathrm{~mm}$ long. Cephalic shield $919 \times 863 \mu \mathrm{m}$, resembling that of female. Genital complex slightly longer than wide. Abdomen 2-segmented, segmentation incomplete; distal somite about twice as long as proximal one. Caudal ramus $88 \times 61 \mu \mathrm{m}$.

Antennule armed as in female. Antenna (Fig. 10F) 3segmented; first segment with 1 adhesion pad; second segment with 2 weak adhesion pads; third segment with 2 inner proximal setae and forming strong claw bearing large subsidiary claw near middle. Postantennal process more slender and longer than that of female.

Mandible, maxillule and maxilla as in female. Maxilliped (Fig. 10G) with 1 corrugation on inner margin of first segment. Sternal furca as in female.

Legs 1-4 also as in female. Leg 5 represented by 4 small setae on lateral margin of genital complex (Fig. 10H). Leg 6 represented by 3 small setae on each posterolateral corner of genital complex (Fig. 10H).

Distribution and hosts. Very diverse species of fishes have been reported as hosts of $C$. rotundigenitalis from Persian Gulf, India, China, Taiwan, and Malaysia. It is parasitic on 33 species of fishes belonging to 19 families in Taiwan (Ho et al., 2000).

Remarks. Ho et al. (2000) mentioned the similarity of C. rotundigenitalis with C. tanago Yamaguti, 1939 and C. mutispinosus Shen, 1957. To this group, we could also keep C. seriolae Yamaguti, 1936. These four species are similar to one another in most of the morphological aspects. However, C. tanago can be separated from the other three by having a narrow abdomen with its nearly parallel lateral margins and a simple (not ramified) ventral rib of the lateral zones of the cephalic shield which can be detected in the dorsal view of body under the microscope. A close comparison of the remaining three species based on the previous records and our available specimens failed to distinguish them. We consider $C$. multispinosus and $C$. seriolae as junior synomyms of $C$. rotundigenitalis. They share the following characteristic features: 1) the ventral rib of the lateral zones of the cephalic shield ramified distally; 2) the antenna lacks a proximal spine on the first segment; 3 ) the postantennal process is small in the female; 4) the distal tines of the sterna furca are broad, with blunt tip; 5) the rudimentary endopod of leg 1 is blunt; 6) the outermost distal spine (spine I) of the distal exopodal segment of leg 1 is spiniform and much smaller than other 3 distal spines which are naked, setiform, and similar in length, without accessory element; and 7) the distalmost spine of leg 4 is nearly smooth and distinctly longer than four proximal spines which are plumose and setiform.

\section{Genus Pseudocaligus A. Scott, 1901}

\section{Pseudocaligus longipes n. sp. \\ (Figs. 11, 12)}

Material examined. 1 우, $10^{7}$ from gills of Siganus fuscesens (Houttuyn), at Sagye, Jeju Island, M.-K. Choe, 16 August 2009. Holotype (우: antennule, maxilliped and leg 1 of right side and left and right leg 4 dissected out) and allotype (antenna, maxilliped and leg 4 of right side dissected out) have been deposited in the National Institute of Biological Resources, Incheon. Dissected appendages are kept in the collection of the junior author.

Female. Body (Fig. 11A) narrow, $1.98 \mathrm{~mm}$ long. Cephalothoracic shield longer than wide, $1.19 \times 0.84 \mathrm{~mm}$, with thin lateral membrane; thoracic zone extending far beyond lateral zone; ventral rib of lateral zone short, linear, with indistinct distal end; posterolateral pit present; posterior sinus shallow. Fourth pedigerous somite short and fused with genital complex. Genital complex large, 600 $\times 669 \mu \mathrm{m}$, with rounded anterolateral and posterolateral corners. Abdomen short $105 \times 154 \mu \mathrm{m}, 1$-segmented, and gradually narrowed distally. Caudal ramus $98 \times 46 \mu \mathrm{m}$, 2.13 times as long as wide, with 6 setae, and setules on distal half of inner margin.

Antennule (Fig. 11C) $185 \mu \mathrm{m}$ long and 2-segmented; proximal segment occupying $63 \%$ length of antennule, with 26 pinnate and 2 naked setae; distal segment with 12 naked setae and 2 aesthetascs. Antenna 3-segmented (Fig. 11D); first segment with large, tapering and pointed proximal process; second segment nearly quadrangular; third segment forming large, distally strongly bent claw bearing 2 small setae. Postantennal process with 2 papillae each tipped with 2 setules; another papilla located posterior to postantennal process tipped with 2 setules; small claw-like element present posterior to postantennal process (Fig. 11D).

Mandible with 12 teeth distally. Maxillule consisting of anterior papilla bearing 3 unequal setae and short, strongly tapering posterior process (Fig. 11D). Maxilla (Fig. 11E) 2-segmented; proximal segment unarmed; slender distal segment distinctly longer than proximal segment, with small membrane (flabellum) at $67 \%$ region of inner margin; calamus slightly longer than canna. Maxilliped (Fig. 11F) 3-segmented; first segment unarmed; second segment with 1 distal seta; third segment forming strongly curved claw, much shorter than second seg- 


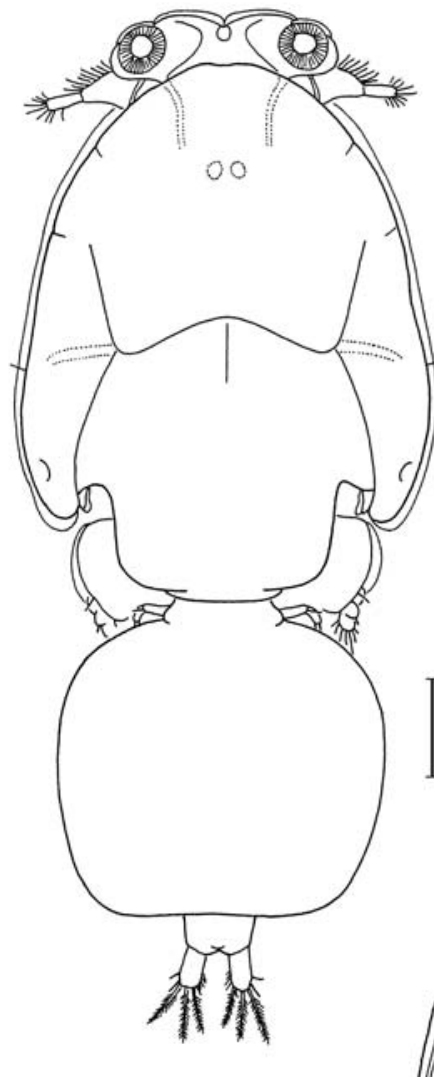

A
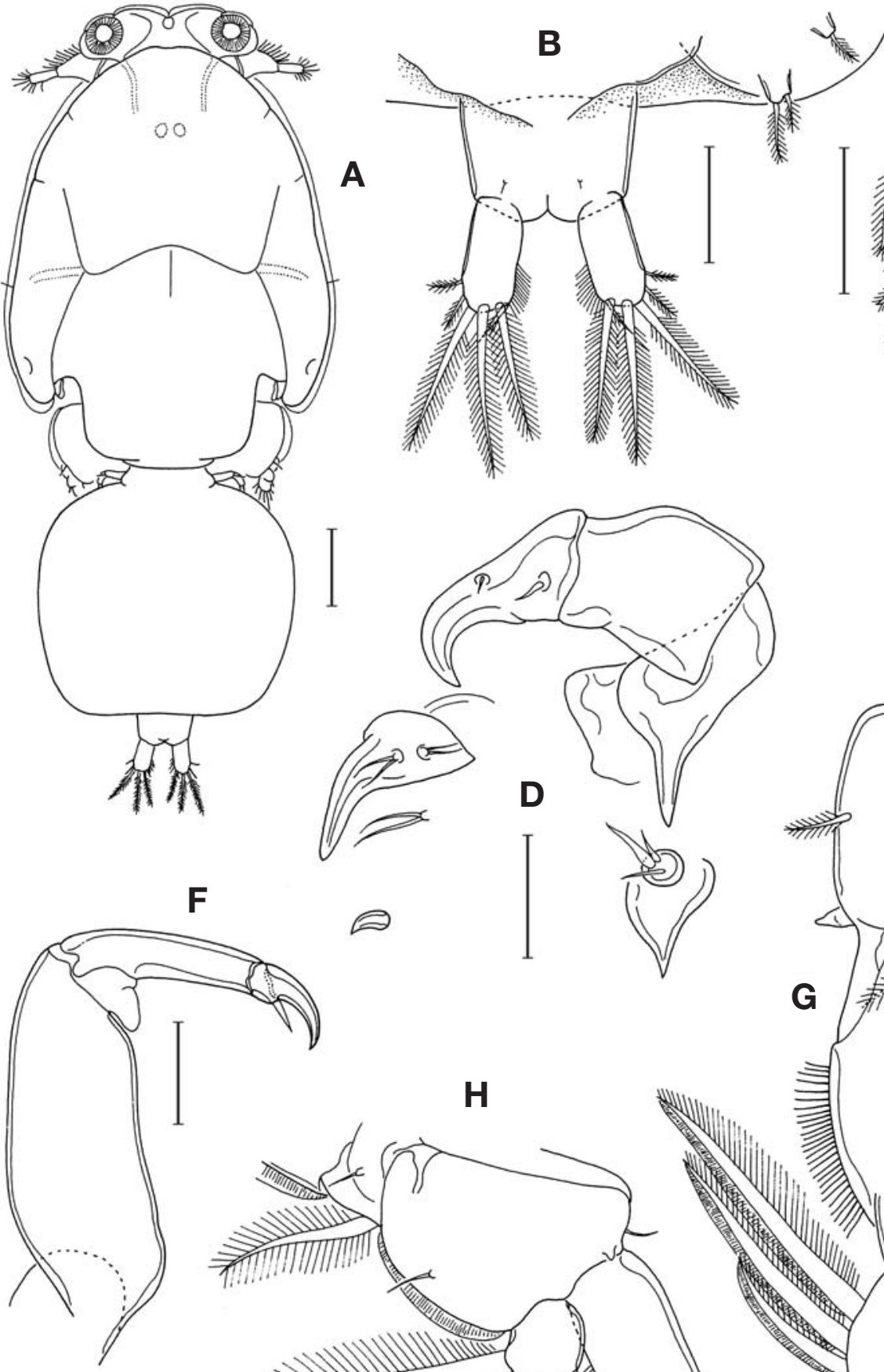

$\mathbf{F}$
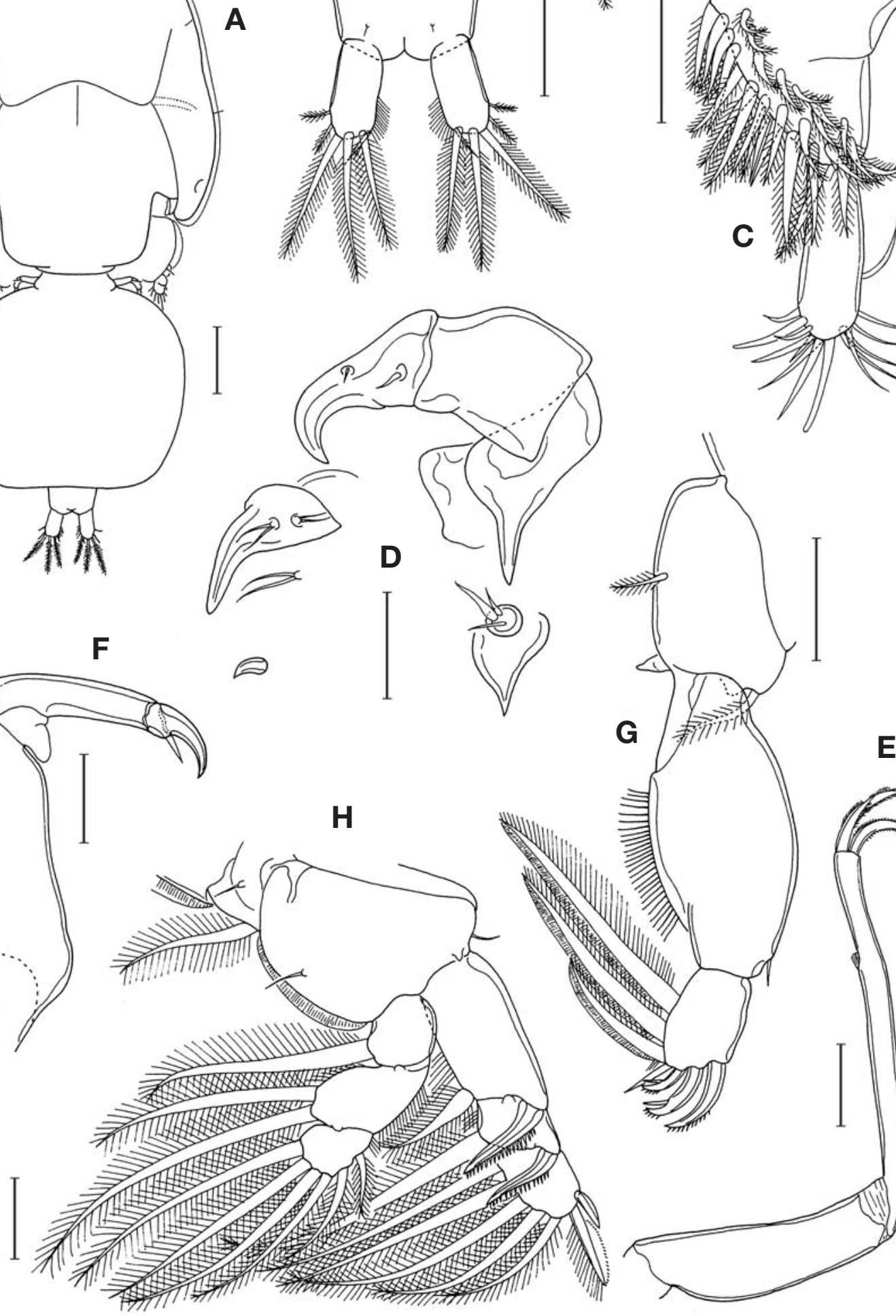

E

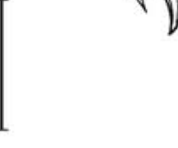

H
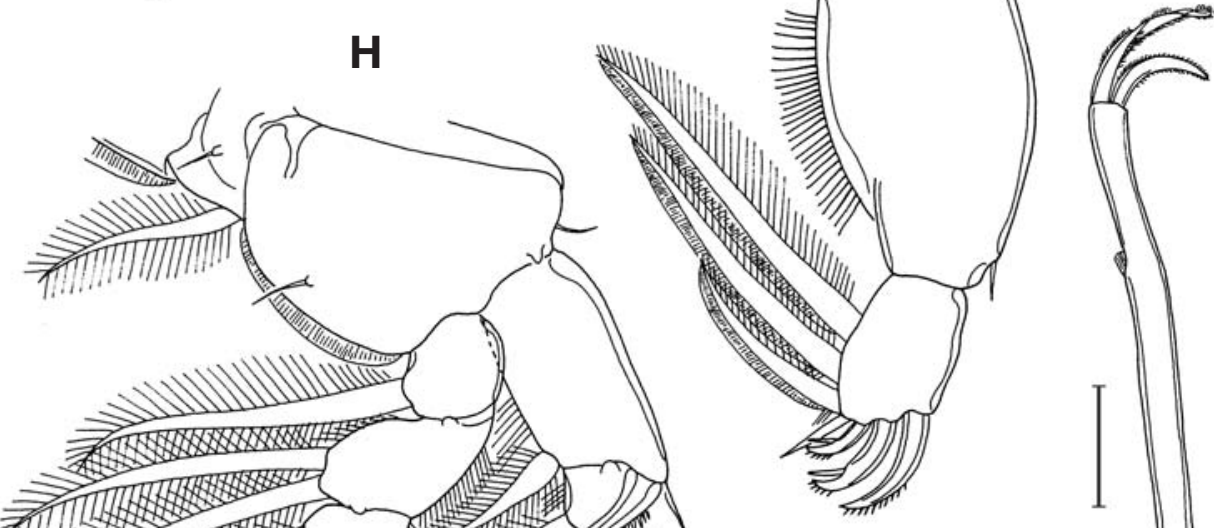

Fig. 11. Pseudocaligus longipes n. sp., female. A. habitus, dorsal. B. abdomen, ventral. C. antennule. D. antenna, postantennal process, and maxillule. E. maxilla. F. maxilliped. G. leg 1. H. leg 2. Scales=A. $0.2 \mathrm{~mm}$. B. $0.1 \mathrm{~mm}$. C-H. $0.05 \mathrm{~mm}$. 


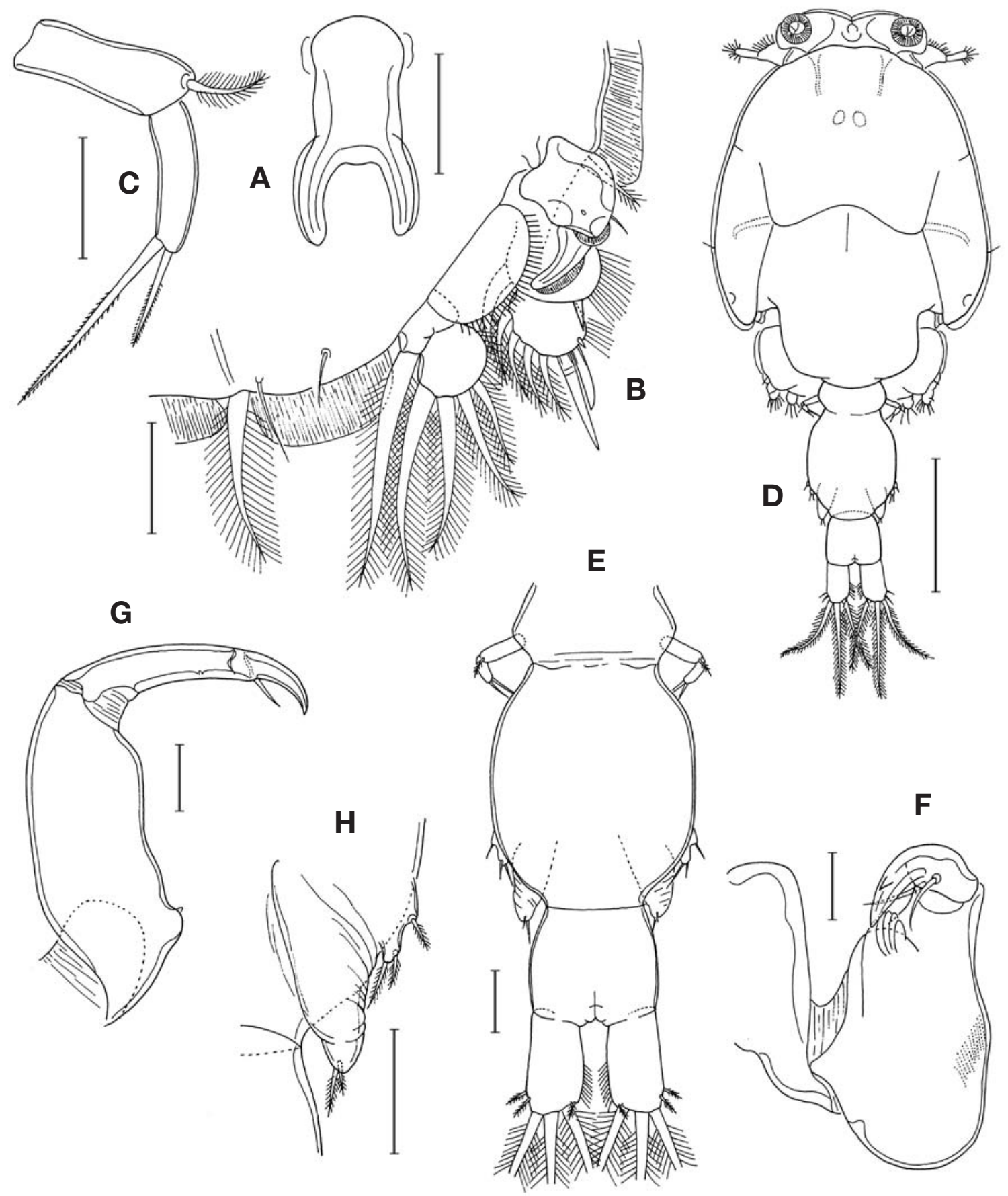

Fig. 12. Pseudocaligus longipes n. sp., female. A. sternal furca. B. leg 3. C. leg 4. Male. D. habitus, dorsal. E. urosome, dorsal. F. antenna. G. maxilliped. H. legs 5 and 6. Scales=A-C, F-H. $0.05 \mathrm{~mm}$. D. $0.5 \mathrm{~mm}$. E. $0.1 \mathrm{~mm}$.

ment. Sternal furca (Fig. 12A) with incurved tines bearing transparent flange on outer margin; tines shorter than basal part of sternal furca.

Armature on rami of legs 1-4 as follows:

Leg 1: exopod 1-0; III,1,3; endopod (vestigial)

Leg 2: exopod I-1; I-1; I,I,5; endopod 0-1; 0-2; 6
Leg 3: exopod I-0; I-1; III,4; endopod 0-1; 4

Leg 4: exopod 2; endopod (lacking)

Leg 1 (Fig. 11G) basis with pinnate outer and inner setae. Proximal exopodal segment fusiform, widest in middle, with 1 small outer distal naked seta and row of setules on inner margin; three distal spines on distal seg- 
ment gradually shorter from outer to inner, inner two of them each bearing seta; distal seta small and naked. Endopod vestigial and tapering. Leg 2 (Fig. $11 \mathrm{H}$ ) coxa with large seta on inner posterior margin and 1 setule inner ventral surface; basis with small outer seta and 1 inner setule and membrane on inner part of posterior margin; outer spines on first and second exopodal segments large and denticulate along outer (distal) margin. Leg 3 (Fig. 12B) protopod (apron) with broad membrane on outer and inner margins; spine on first exopodal segment bearing hyaline flange along outer margin; proximal spine on third exopodal segment rudimentary, much smaller than distal spines. Leg 4 (Fig. 12C) protopod $67 \times 28 \mu \mathrm{m}$, with outer distal seta; exopod 1-segmented $61 \times 18 \mu \mathrm{m}$, 3.39 times as long as wide, with 2 distal setae of $41 \mu \mathrm{m}$ (outer) and $90 \mu \mathrm{m}$ (inner); both setae bearing spinules on margins. Leg 5 represented by 1 knob tipped by 1 seta and another distal knob tipped by 2 setae on posterolateral area of genital complex.

Male. Body (Fig. 12D) larger than female, $2.22 \mathrm{~mm}$ long. Cephalic shield resembling that of female. Urosome (Fig. 12E) rather narrow. Genital complex $404 \times 342 \mu \mathrm{m}$. Abdomen 1-segmented and $188 \times 212 \mu \mathrm{m}$. Caudal ramus $173 \times 92 \mu \mathrm{m}, 1.88$ times as long as wide.

Antennule as in female. Antenna (Fig. 12F) 3-segmented as in female; first segment unarmed and distinctly narrowed distally; second segment expanded proximally, with 2 small adhesion pads; third segment with 2 proximal setae and forming strong claw bearing 1 denticle. Postantennal process bearing papillae tipped with 2 or 3 setules.

Mandible, maxillule and maxilla as in female. Maxilliped (Fig. 12G) with proximal protuberance tipped with 1 small seta. Sternal furca as in female.

Legs 1-4 also as in female. Leg 5 represented by lobe bearing 3 setae (Fig. 12H). Leg 6 represented by 2 small setae on genital flap (Fig. 12H).

Etymology. The specific name longipes is derived from the Latin longus (long) and pes (foot). It alludes to the elongate exopod of leg 4 of the new species.

Remarks. Nine species are currently known in the genus Pseudocaligus. Of these, only two species, $P$. fistulariae Pillai, 1961 and P. uniartus Ho et al., 2004, are known to have two-segmented leg 4 (protopod and one-segmented exopod), as the new species.

Pseudocaligus longipes $\mathrm{n}$. sp. differs from $P$. fistulariae in having a short, one-segmented abdomen (vs. elongate and two-segmented in $P$. fistulariae), seven elements with the armature of III,1,3 on the distal exopodal segment of leg 1 (vs. five elements with armature of III,1,1 in $P$. fistulariae), four setae on the distal endopodal segment of leg 3 (six setae in P. fistulariae), smaller body size (vs. larger body size, length $5.1 \mathrm{~mm}$ in the female of $P$. fistulariae cf. Pillai, 1961), and different configuration of the genital complex (which is longer than wide in $P$. fistulariae). Pseudocaligus fistulariae was recorded as parasite of Fistularia villosa Kluzinger in India(Pillai, 1961).

The new species also differs from $P$. uniartus in having seven elements on the third exopodal segment of leg 3 with the armature of III,4 (vs. III,3 in P. uniartus), four setae on the distal endopodal segment of the same leg(vs. three setae in $P$. uniartus), more slender caudal ramus which is 2.13 times as long as wide (1.11 times as long as in $P$. uniartus), and elongate exopod of leg 4 which is 3.39 times as long as wide (only slightly longer than wide in P. uniartus). Pseudocaligus uniartus was recorded as a parasite of Siganus guttatus (Bloch) and Lutjanus argentimaculatus (Forsskål) both cultured in the Philippines (Ho et al., 2004).

\section{Genus Metacaligus Thomsen, 1949}

\section{Metacaligus uruguayensis (Thomsen, 1949) \\ (Figs. 13, 14)}

Caligus (Metacaligus) uruguayensis Thomsen, 1949, p. 3, pl. 2, figs. 1-25; pl. 3, figs. 1-21.

Caligus longicorvicis Gnanamuthu, 1950. p. 115, pl. 3, figs. 31-46; Kirtisinghe, 1964, p. 65, fig. 57; Pillai, 1966, p. 125, fig. 2.

Metacaligus uruguayensis: Ho and Bashirullah, 1977. p. 707, figs. 3, 4; Lin and Ho, 2000, p. 206, figs. 4-6; Ho and Lin, 2004, p. 302, figs. 159-161.

Material examined. 2 우 우, $10^{7}$ from Trichurus lepturus, Linnaeus at Sorae Port (the fish was imported from Jeju Island), S. Y. Moon, 10 October 2009.

Female. Body (Fig. 13A) large and narrow, $6.08 \mathrm{~mm}$ long. Cephalothoracic shield subcircular, $2.30 \times 2.10 \mathrm{~mm}$; lateral zone with weakly curved ventral rib and small posterolateral pit; posterior sinus deep. Thoracic zone extending to level of posterior end of lateral zone. Urosome longer than prosome. Fourth pedigerous somite narrow and fused with genital complex. Genital complex large, ovoid, widest in middle, $2.10 \times 1.56 \mathrm{~mm}$. Abdomen about $600 \times 362 \mu \mathrm{m}, 1$-segmented, with slightly convex lateral margins. Caudal ramus (Fig. 13C) weakly tepering, $185 \times 85 \mu \mathrm{m}, 2.18$ times as long as wide, with 6 setae; longest one of caudal setae $300 \mu \mathrm{m}$.

Antennule (Fig. 13D) 2-segmented; proximal segment $228 \mu \mathrm{m}$ long, with 27 setae; distal segment elongated, 208 $\mu \mathrm{m}$ long, with 12 naked setae and 2 aesthetascs. Antenna 3-segmented; first segment without proximal process; second segment nearly quadrangular; third segment longer than segment, forming long, with 2 small setae (Fig. 13E). Postantennal process small, triangular, with 2 papillae each tipped with 1 or 2 setules (Fig. 13E); another papilla located posterior to postantennal process tipped with 1 setule. 


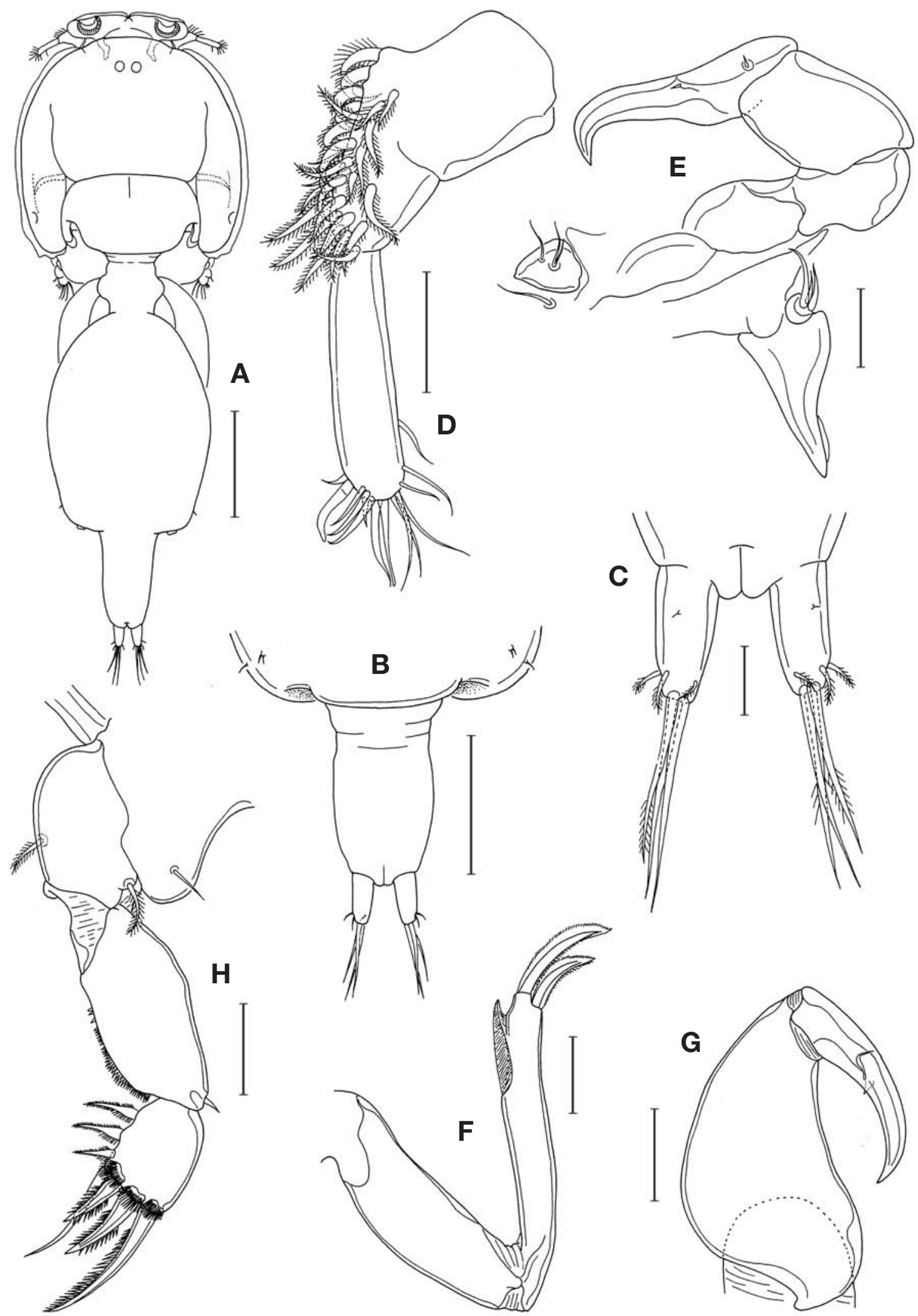

Fig. 13. Metacaligus uruguyensis (Thomsen), fmale. A. habitus, dorsal. B. abdomen, ventral. C. caudal rami. D. antennule. E. antenna, postantennal process, and maxillule. F. maxilla. G. maxilliped. H. leg 1. Scales=A. $1 \mathrm{~mm}$. B. $0.5 \mathrm{~mm}$. C-F, H. $0.1 \mathrm{~mm}$. G. $0.2 \mathrm{~mm}$. 


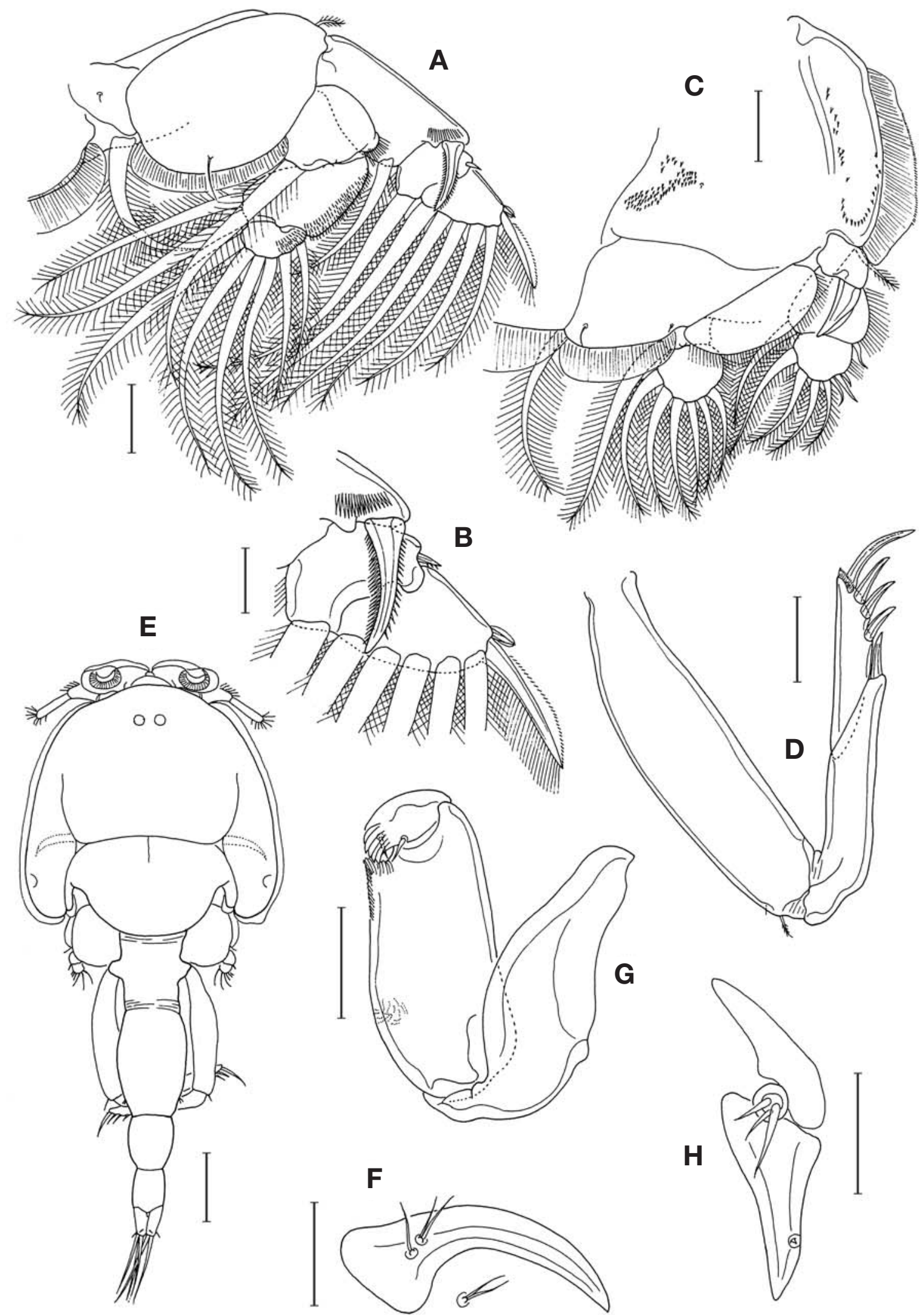

Fig. 14. Metacaligus uruguyensis (Thomsen), female. A. leg 2. B. second and third exopodal segment of leg 2. C. leg 3. D. leg 4. Male. E. habitus, dorsal. F. postantennal process. G. antenna. H. maxillule. Scales=A, C, F-H. $0.1 \mathrm{~mm}$. B. $0.05 \mathrm{~mm}$. D. $0.2 \mathrm{~mm}$. E. $0.5 \mathrm{~mm}$. 
Mandible with 12 teeth distally. Maxillule consisting of anterior papilla bearing 3 unequal setae and tapering posterior process. Maxilla (Fig. 13F) 2-segmented; proximal segment unarmed; distal segment with large subdistal membrane (flabellum) on inner margin; calamus about 1.3 times longer than canna, both with serrate margins. Maxilliped (Fig. 13G) 3-segmented and stocky; first segment strongly tapering distally; second segment with 1 small setiform process distally; third segment almost fused with second, forming strong claw. Sternal furca absent.

Armature on rami of legs 1-4 as follows:

Leg 1: exopod 1-0; III,1,3; endopod (vestigial)

Leg 2: exopod I-1; I-1; I,I,5; endopod 0-1; 0-2; 6

Leg 3: exopod I-0; 1-1; 3,4; endopod $0-1 ; 6$

Leg 4: exopod I-0; IV; endopod (lacking)

Leg 1 (Fig. 13H) coxa with simple outer setule; basis with pinnate outer and inner setae. Proximal exopodal segment with 1 small outer distal naked seta and row of spinules on inner margin; distal segment $113 \times 88 \mu \mathrm{m}$, broad, three distal spines very unequal in size, 165, 105, and $75 \mu \mathrm{m}$ from outer to inner, each accompanied by pectin near base; inner distal seta naked; 3 inner setae small, not longer than distal segment; endopod small, knob-like. Leg 2 (Fig. 14A) coxa with large seta on inner posterior margin; basis with small outer seta and 1 inner setule. Outer spine of second exopodal segment and outer proximal spine on third segment small (Fig. 14B). Second and third endopodal segments with spinules on outer surface. Leg 3 (Fig. 14C) protopod (apron) with spinules on midventral and outer ventral surfaces. Leg 4 (Fig. 14D) protopod longer than exopod, with small outer distal seta. Exopod 2-segmented; proximal segment longer than distal segment, its distal spine $110 \mu \mathrm{m} ; 4$ spines on distal segment $105,115,134$, and $210 \mu \mathrm{m}$, from proximal to distal. Leg 5 represented by 1 and 3 small setae on posterolateral area of genital complex (Fig. 13B).

Male. Body (Fig. 14E) $4.19 \mathrm{~mm}$ long, with narrow urosome. Cephalic shield $1.98 \times 1.83 \mathrm{~mm}$. Genital complex $808 \times 529 \mu \mathrm{m}$, nearly fusiform. Abdomen 2-segmented, $385 \times 337$ (proximal) and $288 \times 232 \mu \mathrm{m}$ (distal segment).

Antennule as in female. Antenna (Fig. 14G) 3-segmented as in female; first segment unarmed; second segment with 2 weak adhesion pads; third segment short, with 2 inner proximal setae and distally forming several layers of leaf-like flaps. Postantennal process (Fig. 14F) large and very different from that of female.

Mandible and maxilla as in female. Maxillule (Fig. 14H) with 1 small subdistal seta on posterior process. Maxilliped as in female. Sternal furca absent.

Legs $1-5$ as in female. Leg 6 represented by 2 small setae on each posterolateral corner of genital complex.

Distribution and hosts. Known hosts of Metacaligus uruguayensis are Trichiurus haemula (Forskål) in India, T. lepturus Linnaeus in Uruguay, Venezuela, Taiwan and Korea (present study), T. savala Cuvier in India and Sri Lanka, and Trichiurus sp. in Brazil(Lin and Ho, 2000).

Remarks. The genus Metacaligus is distinguished from other genera of the Caligidae by the combination of the following characters (Ho and Bashiru-llah, 1977; Ho and Lin, 2002): 1) the absence of sternal furca; 2) the absence of accessory process on two mid-terminal spines of the second exopodal segment of leg $1 ; 3$ ) the possession of only one outer spine (instead of two) on the terminal exopodal segment of leg 2.

The cutlassfish Trichiurus lepturus harbors another species of Metacaligus, M. latus described by Ho and Lin (2002) from Taiwan. According to Ho and Lin (2002), in $M$. latus the genital complex of both sexes is globular and almost as long as wide, the caudal ramus is 1.63 times as long as wide in the female, the postantennary process has papillae tipped with 4 setules, and the anal somite of the male is distinctly longer than the proximal abdominal somite. C. uruguayensis may be easily differentiated from $M$. latus based on those features of the latter species.

\section{Genus Lepeophtheirus Nordmann, 1832}

\section{Lepeophtheirus atypicus Lin, Ho and Chen, 1996 (Figs. 15, 16) \\ Lepeophtheirus atypicus Lin et al., 1996, p. 130, figs. 1- 3; Ho and Lin, 2004, p. 277, figs. 145-147.}

Material examined. 2 우 우 from Siganus fuscesens (Houttuyn), at Sagye, Jeju Island, M.-K. Choe, 16 August 2009.

Female. Body (Fig. 15A) flat, $2.18 \mathrm{~mm}$ long. Cephalothoracic shield subcircular, $1.45 \times 1.34 \mathrm{~mm}$; lateral zone with weakly curved, simple ventral rib and minute setules along lateral margin; posterior sinus deep. Thoracic zone broad and extending over posterior end of lateral zone. Fourth pedigerous somite short. Genital complex much wider than long, $421 \times 719 \mu \mathrm{m}$, with rounded corners. Abdomen $108 \times 163 \mu \mathrm{m}$ and 1-segmented (Fig. 17B). Caudal rami widely separated from each other; each ramus (Fig. 15C) $106 \times 40 \mu \mathrm{m}, 2.65$ times as long as wide, with 6 setae, 2 proximal ones of them located on ventral surface.

Antennule (Fig. 15D) $199 \mu \mathrm{m}$ long and 2-segmented; proximal segment occupying $72 \%$ length of antennules, with 1 pointed process and 26 setae; distal segment stout, with 11 naked setae and 2 aesthetascs. Antenna 3-segmented; first segment with distinct proximal process (Fig. $15 \mathrm{E})$; second segment nearly quadrangular, with 1 adhesion pad; third segment forming large, distally strongly bent claw bearing 2 small setae. Postantennal process 2 papillae each tipped with 4 or 5 setules (Fig. 15E); anoth- 


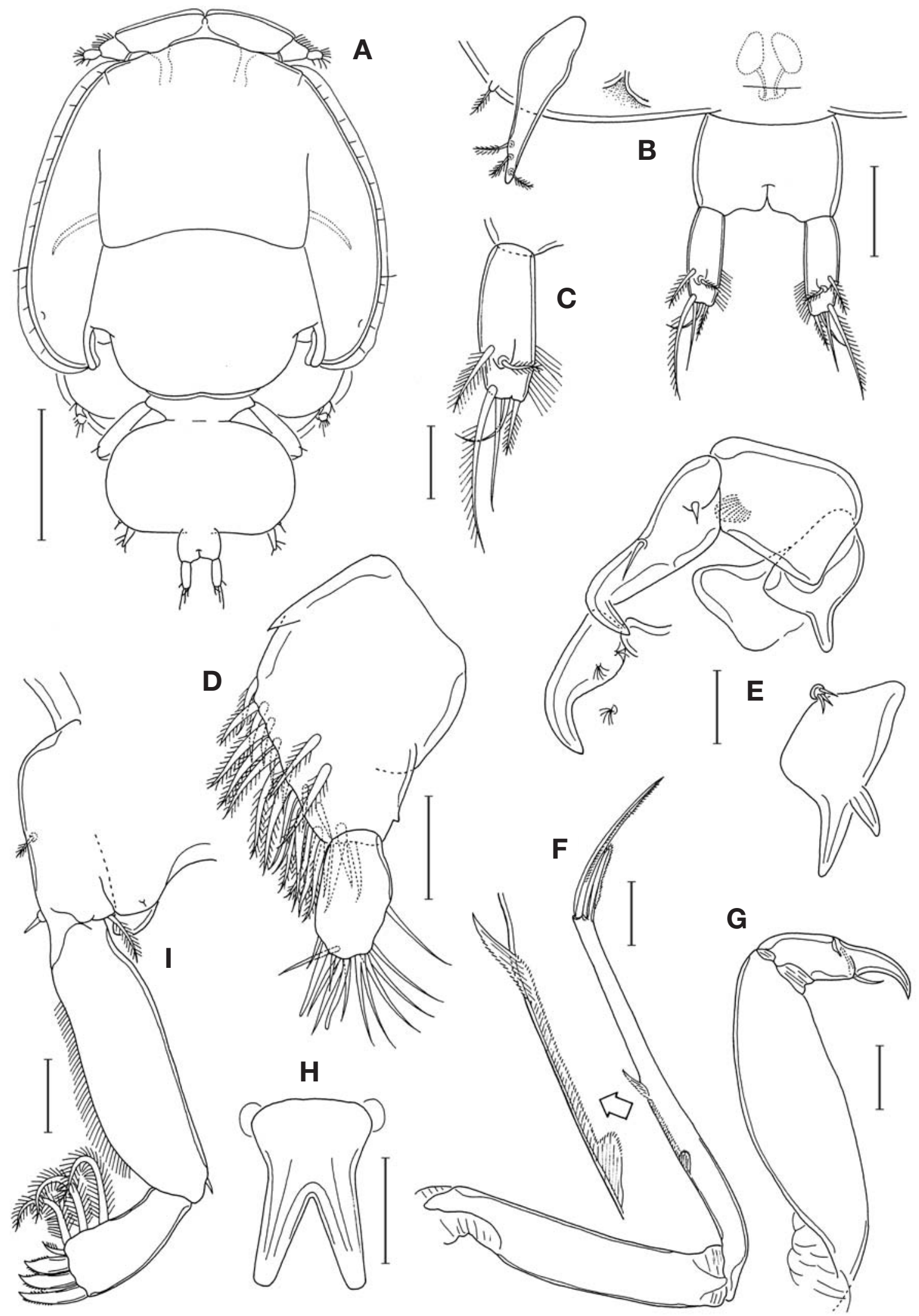

Fig. 15. Lepeophtheirus atypicus Lin, Ho and Chen, female. A. habitus, dorsal. B. abdomen, ventral. C. caudal ramus, ventral. D. antennule. E. antenna, postantennal process, and maxillule. F. maxilla. G. maxilliped. H. sternal furca. I. leg 1 . Scales=A. $0.5 \mathrm{~mm}$. B. 0.1 mm. C-I. $0.05 \mathrm{~mm}$. 


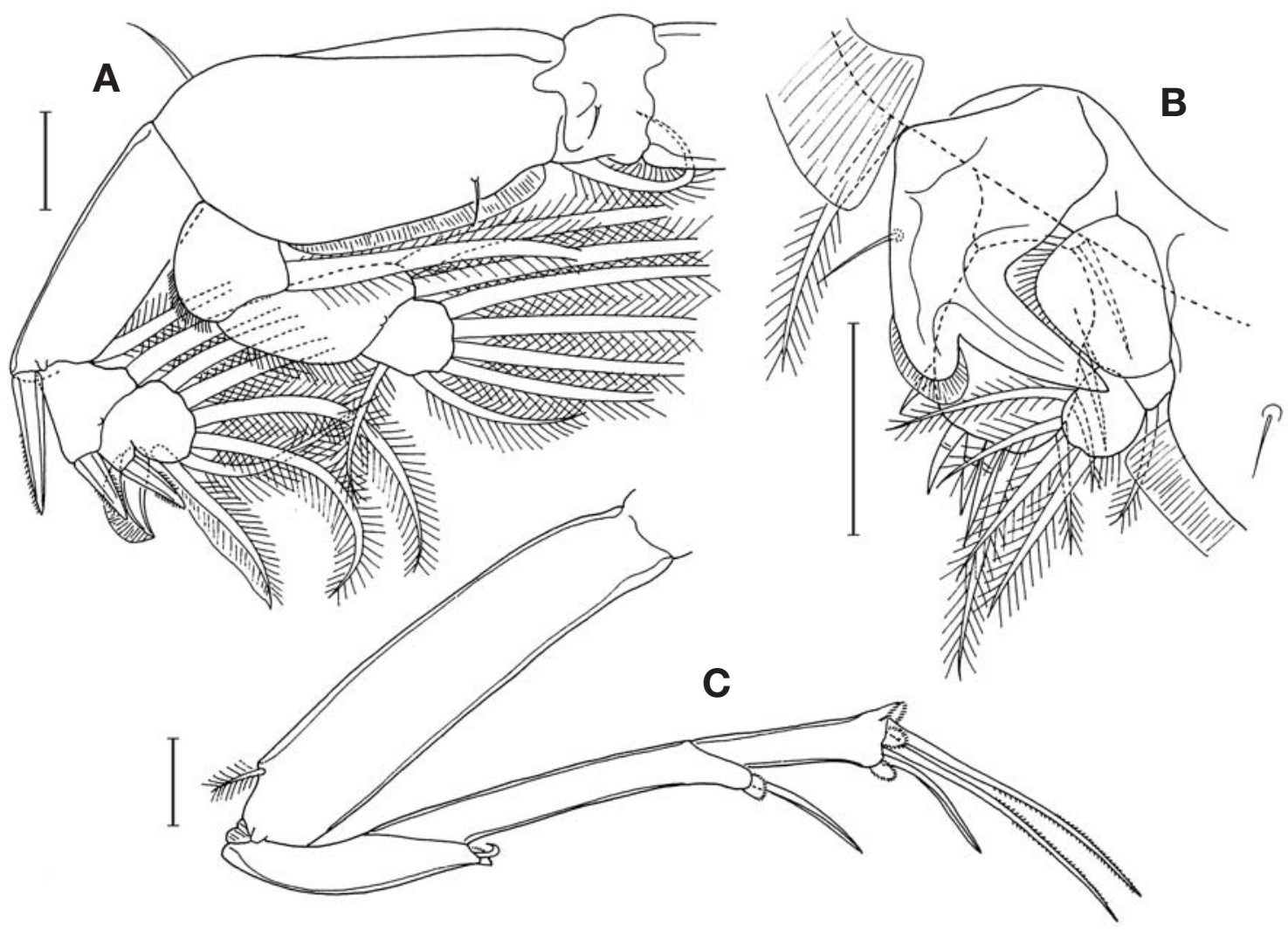

Fig. 16. Lepeophtheirus atypicus Lin, Ho and Chen, female. A. leg 2. B. leg 3. C. leg 4. Scales $=0.05 \mathrm{~mm}$ for all.

er papilla located posterior to postantennal process also tipped with 5 setules.

Mandible with 12 teeth distally. Maxillule consisting of anterior papilla bearing 3 small setae and posterior process bearing 2 tines (Fig. 15E). Maxilla (Fig. 15F) very slender and 2-segmented; proximal segment (lacertus) unarmed; distal segment (brachium) elongated, distinctly longer than proximal segment, with long membrane (flabellum) at region slightly proximal to middle of on inner margin; calamus about twice as long as canna. Maxilliped (Fig. 15G) 3-segmented; first segment (corpus) widest in middle, with almost straight inner margin; second segment (shaft) short, with 1 distal seta; third segment nearly as long as second segment, forming curved claw. Sternal furca (Fig. 15H) with divergent tines; each tine straight, tapering, but with blunt tip.

Armature on rami of legs 1-4 as follows:

Leg 1: exopod 1-0; III,1,3; endopod (vestigial)

Leg 2: exopod I-1; I-1; II,I,5; endopod 0-1; 0-2; 6

Leg 3: exopod I-1; IV,4; endopod 0-1; 4

Leg 4: exopod I-0; I-0; III; endopod (lacking)

Leg 1 (Fig. 15I) basis with pinnate outer seta and smaller pinnate inner seta. Proximal exopodal segment with 1 small outer distal naked seta and row of setules on inner margin; distal segment broadened distally; three distal spines broad, somewhat scalpel-form and not branched; distal seta much smaller than distal spines. Leg 2 (Fig. 16A) coxa with large seta on inner posterior margin and 1 setule on ventral surface; basis with outer seta and 1 inner setule and membrane on inner part of posterior margin; Leg 3 (Fig. 16B) with 2-segmented rami; first exopodal segment with large distal spines and 1 setule on outer margin. Leg 4(Fig. 16C) protopod with small outer distal seta. Exopod slender and distinctly longer than protopod; outer spine on first segment small and recurved, hooklike; second segment longer than first or third segments, its distal spine $79 \mu \mathrm{m}$; three spines on third segment 83 , 175 , and $177 \mu \mathrm{m}$ from outer to inner; all spines on exopodal segments accompanied with flabelliform membranes near base. Leg 5 represented by 1 seta on small papilla and 3 setae on elongate plate (this plate well extending over posterior margin of genital complex) on posterolateral side of genital complex (Fig. 15B).

Male. Unknown in Korea.

Distribution and host. Only from Siganus fuscesens (Houttuyn) in Taiwan and Japan (Lin et al., 1996) and Korea (present study).

Remarks. The close relative of Lepeophtherirus atypicus is L. goniistii Yamaguti, 1936 (Lin et al., 1996). However, 
L. atypicus obviously differ from L. goniistii in the following features of the female: 1) caudal rami are widely separated from each other and 2.65 times as long as wide (both closed and 1.30 times as long as wide in L. goniistii, according to Kim, 2008); 2) tines of sternal furca are blunt at tip (pointed in L. goniistii); 3) two middle spines on terminal margin of distal exopodal segment of leg 1 are simple, not bifurcated; 4) the distal endopodal segment of leg 3 bears 4 setae (6 setae in L. goniistii); and 5 ) two inner terminal spines on leg 4 are similar in length.

\section{Lepeophtheirus parvulus Shiino, 1952 \\ (Figs. 17, 18) \\ Lepeophtheirus parvulus Shiino, 1952, p. 105, fig. 12.}

Material examined. 4 우 우, 2 지 잠om Sebastiscus marmoratus (Cuvier and Valenciennes), at Donggwi, Jeju Island, M.-K. Choe, 2 August 2009; 1 우, 1 이 from S. marmoratus, at Aeweol in Jeju Island, M.-K. Choe, 30 September 2009.

Female. Body (Fig. 17A) $3.88 \mathrm{~mm}$ long. Cephalothoracic shield subcircular, $2.27 \times 2.17 \mathrm{~mm}$; lateral zone with simple, curved ventral rib; posterolateral pit present on dorsal surface. Thoracic zone extending over posterior end of lateral zone. Genital complex nearly circular, 1.15 $\times 1.25 \mathrm{~mm}$. Abdomen 1-segmented, wider than long, and $233 \times 287 \mu \mathrm{m}$. Caudal rami slightly convergent; each ramus $108 \times 94 \mu \mathrm{m}, 1.15$ times as long as wide, with 6 setae, including small subdistal one on outer margin.

Antennule (Fig. 17C) $381 \mu \mathrm{m}$ long and 2-segmented; proximal segment occupying $73 \%$ length of antennules, with 28 pinnate; distal segment with 12 naked setae and 2 aesthetascs. Antenna 3-segmented (Fig. 17D); first segment with proximal process; second segment nearly quadrangular, with 1 adhesion pad; third segment forming large, distally strongly bent claw bearing 2 small setae. Postantennal process bearing 2 papillae each tipped with 4 or 5 setules (Fig. 17D); another papilla located posterior to postantennal process also tipped with 5 setules.

Mandible with 12 teeth distally. Maxillule consisting of anterior papilla bearing 3 unequal setae and posterior process bearing ramified tine (Fig. 17D). Maxilla (Fig. 17E) 2-segmented; proximal segment (lacertus) unarmed; distal segment (brachium) curved in middle; flabellum located near middle of inner margin and divided into proximal and distal parts; calamus and canna very long, the former about twice as long as the latter. Maxilliped (Fig. 17F) 3-segmented; first segment (corpus) with slightly uneven inner margin; second segment (shaft) short, with 1 distal seta; third segment forming curved claw and longer than second segment. Sternal furca (Fig. 17G) with slightly divergent tines; each tine weakly tapering, with blunt tip.

Armature on rami of legs 1-4 as follows:
Leg 1: exopod 1-0; III,1,3; endopod (vestigial)

Leg 2: exopod I-1; I-1; II,I,5; endopod 0-1; 0-2; 6

Leg 3: exopod I-1; I-1; III,4; endopod 0-1; 6

Leg 4: exopod I-0; I-0; III; endopod (lacking)

Leg 1 (Fig. 17H) basis with pinnate outer and inner setae. Proximal exopodal segment expanded, widest in proximal one-third, with 1 small outer distal seta and row of setules on inner margin; distal segment with 2 flabelliform membrane on distal margin; two inner distal spines bifurcating distally; distal seta pinnate; endopod flexible and tipped with 2 small processes. Leg 2 (Fig. 18A) coxa with large seta on inner posterior margin and 1 small setule on ventral surface; basis with small outer seta and 1 inner setule and membrane on inner part of posterior margin; first endopodal segment with setulose membrane on outer margin; outer spines on exopod large, with membranous flanges on margins). Leg 3 (Fig. 18B) exopod 3segmented; first exopodal segment with 3 setules on outer margin and large distal spine. Leg 4 (Fig. 18C) protopod narrow, with small outer distal seta; 3-segmented exopod slender; its first segment with 1 minute setule on outer margin and 1 small distal seta $(22 \mu \mathrm{m}$ long $)$; second segment longest among segments, with distal seta of $88 \mu \mathrm{m}$ long; 3 spines on third segment 96, 177, and $273 \mu \mathrm{m}$ long, respectively, from outer to inner; innermost one longer than segment. Leg 5 represented by papilla tipped by 1 seta and plate bearing 3 setae on posterolateral margin of genital complex.

Male. Body (Fig. 18D) $2.30 \mathrm{~mm}$ long. Cephalic shield resembling that of female, $1.35 \times 1.34 \mathrm{~mm}$. Urosome (Fig. $18 \mathrm{E})$ small. Genital complex $370 \times 342 \mu \mathrm{m}$. Abdomen $1-$ segmented and $121 \times 175 \mu \mathrm{m}$, gradually broadened distally. Caudal ramus $113 \times 83 \mu \mathrm{m}, 1.36$ times as long as wide.

Antennule similar to that of female. Antenna (Fig. 18F) 3-segmented; first segment with 1 large adhesion pad; second segment greatly expanded proximally, with several adhesion pads; third segment with 2 inner proximal setae and forming strong claw bearing 2 subsidiary claws. Postantennal process with fewer setules on papillae.

Mandible and maxilla as in female. Maxillule (Fig. 18G) with 1 additional, hyaline, aesthetasc-like process on inner side. Maxilliped (Fig. 18H) with 1 small process subdistally on ventral margin and 2 patches of granules on inner distal side. Sternal furca as in female.

Legs 1-4 as in female. Leg 5 represented by 4 small setae on lateral process of genital complex (Fig. 18E). Leg 6 represented by 3 small setae on each posterior process on genital flap (Fig. 18E).

Distribution and host. Only from Sebastiscus marmoratus (Cuvier and Valenciennes) in Japan (Shiino, 1952) and Korea (present study).

Remarks. This is the second record for Lepeophtheirus 


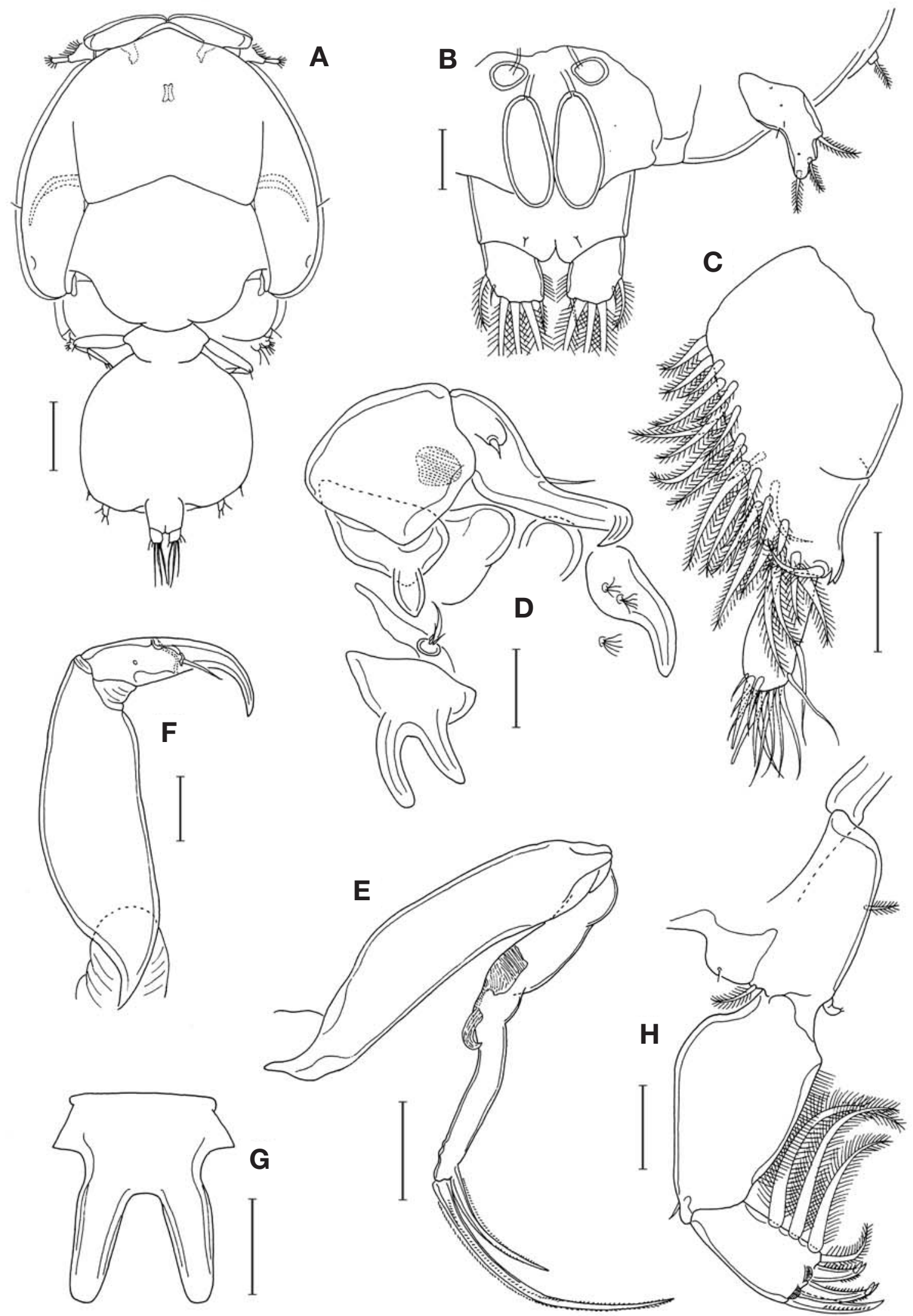

Fig. 17. Lepeophtheirus parvulus Shiino, female. A. habitus, dorsal. B. abdomen, ventral. C. antennule. D. antenna, postantennal process, and maxillule. E. maxilla. F. maxilliped. G. sternal furca. H. leg 1. Scales=A. $0.5 \mathrm{~mm}$. B-H. $0.1 \mathrm{~mm}$. 

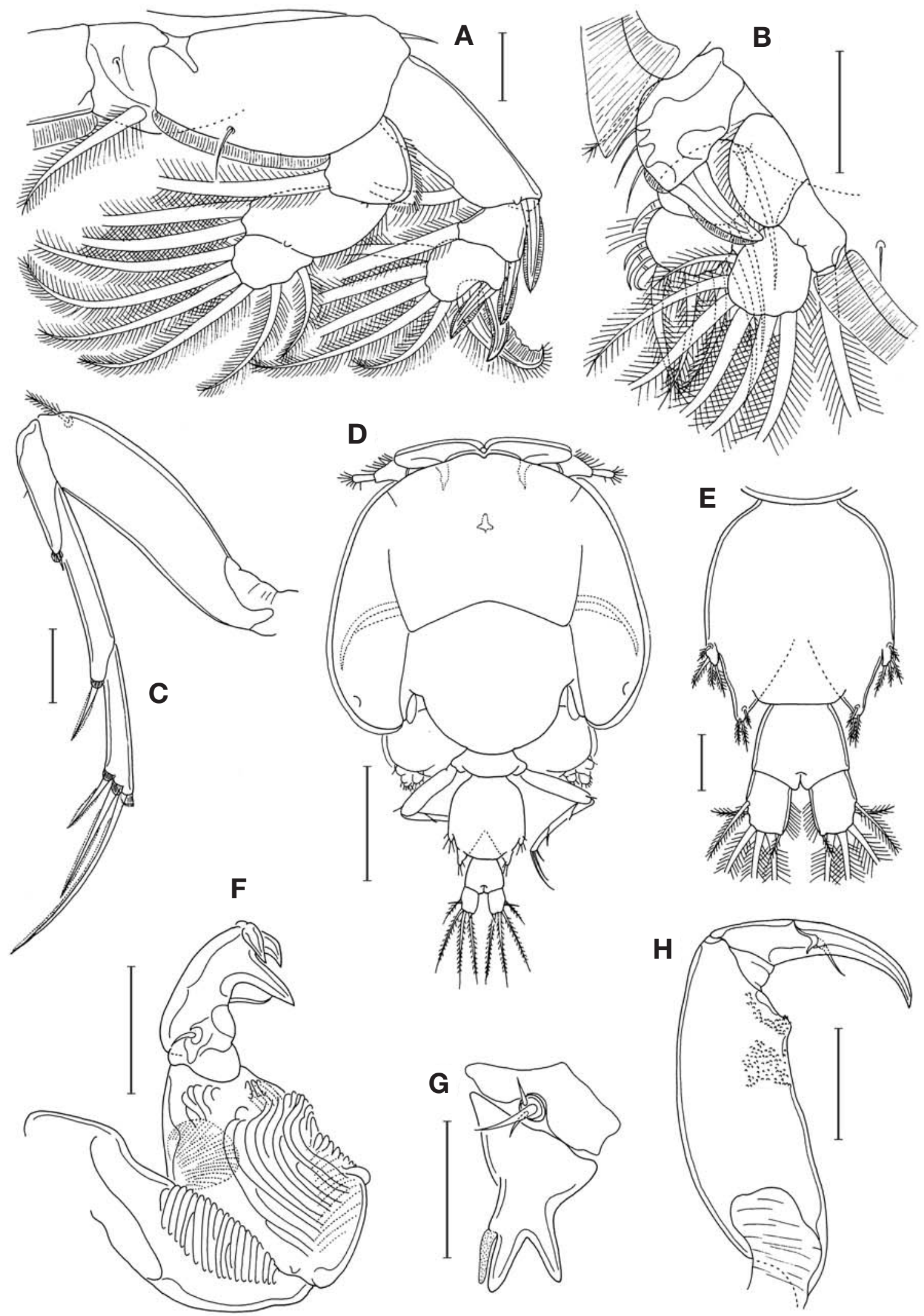

Fig. 18. Lepeophtheirus parvulus Shiino, female, A. leg 2. B. leg 3. C. leg 4. Male. D. habitus, dorsal. E. genital somite and abdomen, dorsal. F. antenna. G. maxillule. H. maxilliped. Scales=A-C, E-H. $0.1 \mathrm{~mm}$. D. $0.5 \mathrm{~mm}$. 
parvulus. The distinguishing features of this species may be as follows: 1) the distal segment of maxilla has a curvature in the middle; 2) the tines of sterna furca are blunt at tip; 3) leg 1 is stout, with two mid-terminal spines being bifurcate at tip; 4) the first exopodal segment of leg 3 bears 3 setules; and 5) the plate of leg 5 extends over posterior margin of genital complex.

\section{Lepeophtheirus tamladus n. sp.} (Figs. 19, 20)

Material examined. 5 우 우, $1 \sigma^{7}$ from the skin of Sebastes inermis Cuvier, at Sagye, Jeju Island, M.-K. Choe, 5 July 2009. Holotype (우) and paratypes (2우 우) have been deposited in the National Institute of Biological Resources, Incheon. Dissected paratypes (2우 우, $10^{7}$ ) are retained in the collection of the junior author.

Other specimens examined. $2 \sigma^{\top} \sigma^{7}$ from Sebastes inermis Cuvier, st Sinheung in Jeju Island, M.-K. Choe, April 2010.

Female. Body (Fig. 19A) $3.45 \mathrm{~mm}$ long. Cephalothoracic shield nearly circular, $2.17 \times 2.10 \mathrm{~mm}$; lateral zone with arched, slender ventral rib; posterior sinus shallow; posterolateral pit on dorsal surface small; membrane on lateral margins very narrow. Fourth pedigerous somite fused with genital complex. Genital complex nearly quadrish, $769 \times 908 \mu \mathrm{m}$. Abdomen indistinctly 2 -segmented (Fig. 19B); first segment $77 \times 212 \mu \mathrm{m}$, much shorter than distal segment; distal segment $135 \times 196 \mu \mathrm{m}$, with nearly parallel lateral margins. Caudal ramus $110 \times 71 \mu \mathrm{m}, 1.55$ times as long as wide, with 6 setae; distal half of inner margin with setules.

Antennule (Fig. 19C) 2-segmented and $350 \mu \mathrm{m}$ long; proximal segment occupying about $70 \%$ length of antennules bearing 27 setae; distal segment bearing 12 naked setae and 2 aesthetascs. Antenna 3-segmented (Fig. 21E); first segment with tapering proximal process; second segment nearly quadrangular, with 1 adhesion pad; third segment forming large distally strongly bent claw bearing 2 small setae. Postantennal process blunt (Fig. 19D), with 2 papillae each tipped with several setules; another papilla located posterior to postantennal process tipped with 6 setules.

Mandible with 12 teeth distally. Maxillule consisting of anterior papilla bearing 3 unequal setae and posterior process bearing 2 tines (Fig. 19E). Maxilla (Fig. 19F) 2segmented; proximal segment (lacertus) unarmed; distal segment (brachium) longer than proximal segment, with flabellum at place slightly proximal to middle of inner margin; distal half of distal segment distinctly narrower than proximal half; calamus about twice as long as canna. Maxilliped (Fig. 19G) 3-segmented; first segment (corpus) moderately wide; second segment (shaft) short, with 1 distal seta; third segment forming strong claw, longer than second segment. Sternal furca (Fig. 19H) with slightly divergent tines; each tine with hyaline flanges along lateral margins.

Armature on rami of legs 1-4 as follows:

Leg 1: exopod 1-0; III,1,3; endopod (vestigial)

Leg 2: exopod I-1; I-1; II,I,5; endopod 0-1; 0-2; 6

Leg 3: exopod I-0; I-1; III,4; endopod 0-1; 6

Leg 4: exopod I-0; I-0; III; endopod (lacking)

Leg 1 (Fig. 19I) coxa with branched outer setule; basis with pinnate outer and inner setae. Proximal exopodal segment gradually narrowed distally, with 1 small outer distal seta and row of setules on inner margin; distal segment with nearly quadrangular; three distal spines each accompanied by flabelliform membrane; two inner distal spines with setiform subdistal process; distal seta pinnate; endopod rudimentary and pointed. Leg 2 (Fig. 20A) similar to that of $L$. parvulus. First exopodal segment of leg 3 with 3 setules on outer margin (Fig. 20B), its distal spine very large. Leg 4 (Fig. 20C) protopod slightly curved, with small outer distal seta; exopod slender and distinctly longer than protopod; distal spine on first segment very small; second segment longest among segments; 3 spines on distal segment distinctly unequal in length; all spines on exopodal segments accompanied with flabelliform membranes near base. Leg 5 represented by small papilla tipped by 1 seta and tapering plate bearing 3 setae and 1 inner process (Fig. 19B) on posterolateral margin of genital complex.

Male. Body $2.17 \mathrm{~mm}$ long, with large cephalothoracic shield and small urosome. Cephalothoracic shield similar to that of female, $1.43 \times 1.39 \mathrm{~mm}$. Urosome (Fig. 20D) $0.75 \mathrm{~mm}$ long. Genital complex $395 \times 333 \mu \mathrm{m}$. Genial flap extendingover posterior margin of genital complex. Abdomen 1-segmented, gradually broadened distally, and $154 \times 175 \mu \mathrm{m}$. Caudal ramus $114 \times 79 \mu \mathrm{m}$.

Antennule armed as in female. Antenna (Fig. 20E) 3segmented as in female; first segment with 1 large and 1 small adhesion pads; second segment greatly expanded, with several adhesion pads; third segment with 1 proximal seta and 1 large subdistal claw and 2 distal smaller claws. Postantennal process (Fig. 20F) with more developed distal tine; proximal papillae each with 2 or 3 setules; posterior papilla with 3 setules.

Mandible and maxilla as in female. Maxillule (Fig. 20G) with 1 additional, aesthetasc-like process on inner side and 1 adhesion pad and accompanied posteromedially by 1 adhesion pad (Fig. 20G). Maxilliped (Fig. 20H) with 2 patches of granule-like minute tubercles on inner side of distal half of first segment. Sternal furca as in female.

Legs 1-4 as in female. Leg 5 represented by 4 setae on lateral lobe of genital complex (Fig. 20I). Leg 6 represented by posterolateral process bearing 3 setae on genital complex. 


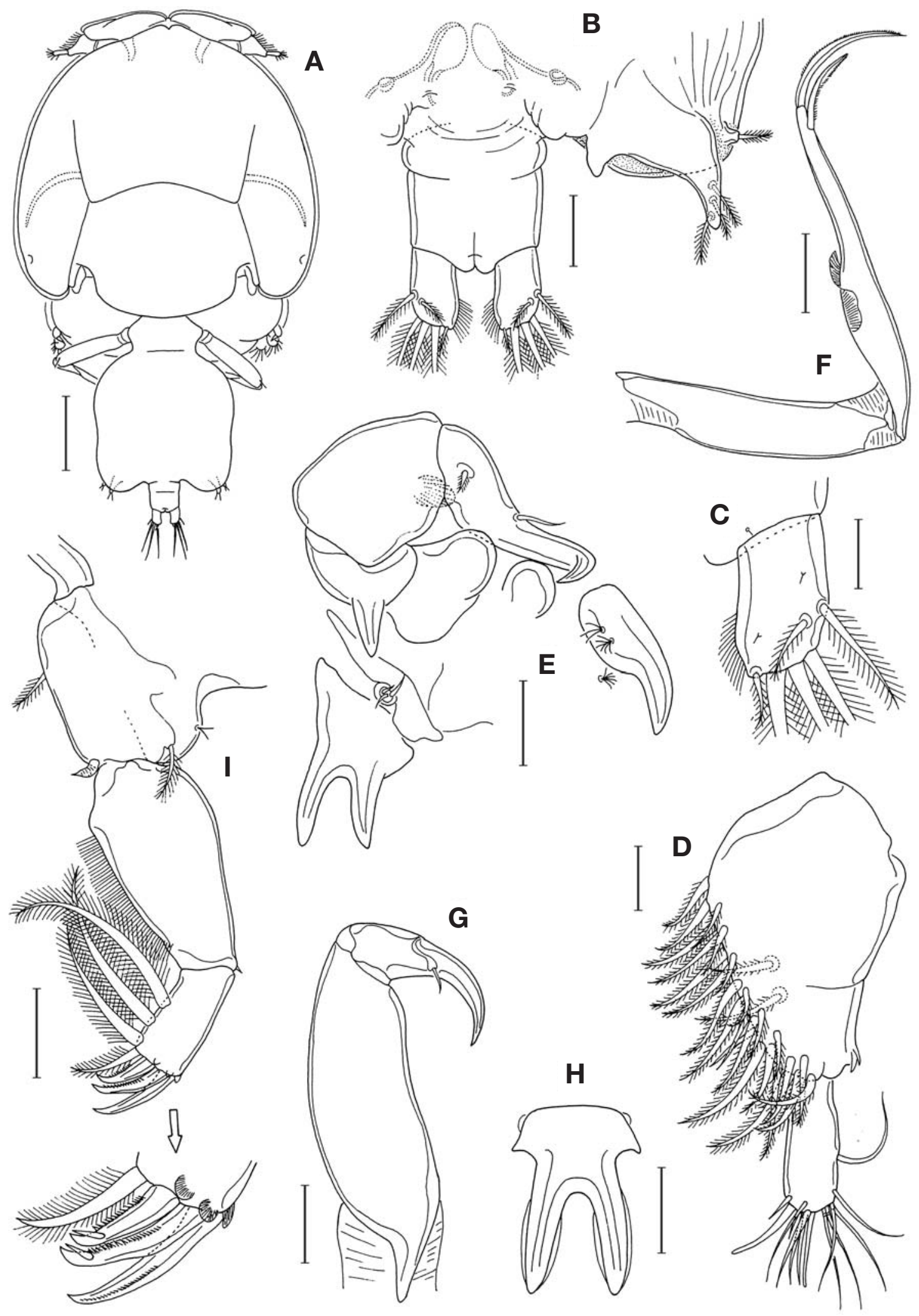

Fig. 19. Lepeophtheirus tamladus n. sp., female. A. habitus, dorsal. B. abdomen, ventral. C. caudal ramus, ventral. D. antennule. E. antenna, postantennal process, and maxillule. F. maxilla. G. maxilliped. H. sternal furca. I. leg 1. Scales=A. $0.5 \mathrm{~mm}$. B, E, F, H, I. $0.1 \mathrm{~mm}$. C. D, G. $0.05 \mathrm{~mm}$. 

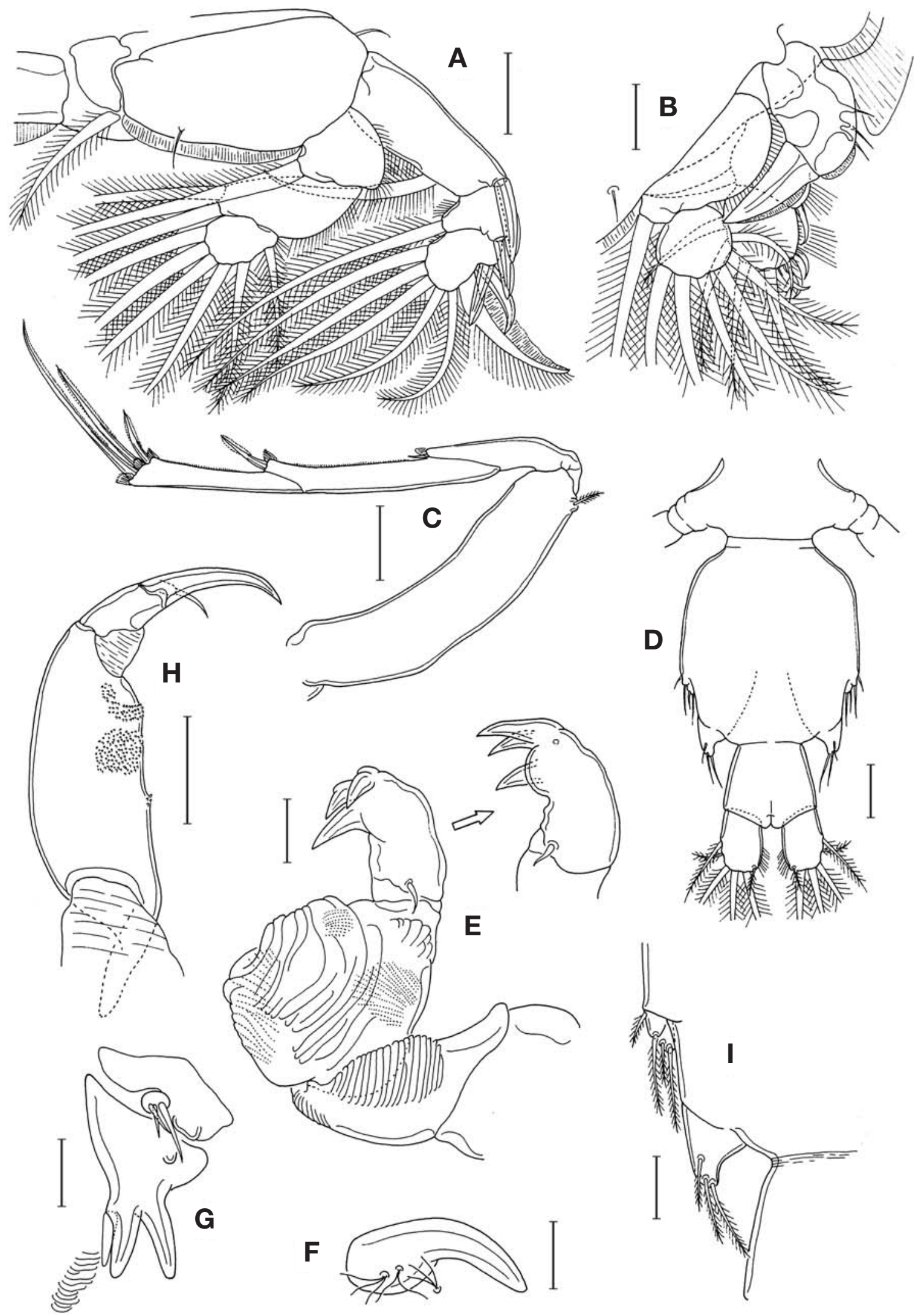

Fig. 20. Lepeophtheirus tamladus n. sp., female. A. leg 2. B. leg 3. C. leg 4. Male: D. urosome, dorsal. E. antenna. F. postantennal process. G. maxillule. H. maxilliped. I. legs 5 and 6. Scales=A, C, D, H. $0.1 \mathrm{~mm}$. B, E-G, I. $0.05 \mathrm{~mm}$. 
Etymology. The specific name is derived from "Tamlado" the old name of Jeju Island, south Korea, the type locality.

Remarks. The new species has the following diagnostic characters: 1) the exopod of leg 4 is 3 -segmented, with armatures of I-0, I-0, III; 2) the maxillule of female bears two tines on posterior process; 3 ) the caudal ramus is distinctly longer than wide; 4) the male maxilliped lacks any process on the medial margin of the first segment; and 5) leg 5 of female is plate-like, extending over the posterior margin of the genital complex. The above features are shared by four congeners: L. anguilli Hameed, 1976; L. chilensis Wilson, 1905; L. hastatus Shiino, 1960; and L. parvulus Shiino, 1952. These four species may be distinguished from the new species by their following features.

In $L$. anguilli the female abdomen is wider than long and the tines of sternal furca are parallel. In L. chilensis the genital complex of the female is wider than long and the abdomen is distinctly 2-segmented. In L. hastatus the tines of sternal furca are narrow. In L. parvulus the genital complex of female is circular, the abdomen is much wider than long, the distal segment of maxilla is curved, and the tines of sternal furca are blunt at tip.

\section{Lepeophtheirus gusevi $\mathrm{n} . \mathrm{sp}$.}

(Figs. 21-23)

Lepeophtheirus sp. Gusev, 1951, p. 421, fig. 17.

Material examined. 7 우 우, $2 \sigma^{7} \sigma^{7}$ from the skin of $\mathrm{Se}$ bastes schlegelii Hilgendorf, at Wando Island in the southern coast of Korea, I.-H. Kim, 10 January 2006. Holotype (우), allotype ( $\sigma^{7}$ ), and paratypes (5우 우) have been deposited in the National Institute of Biological Resources, Incheon. Dissected paratypes (1우, $\left.1 \sigma^{7}\right)$ are retained in the collection of the senior author.

Female. Body (Fig. 21A) $6.67 \mathrm{~mm}$ long. Cephalothoracic shield subcircular, $3.88 \times 3.68 \mathrm{~mm}$, with broad membrane on lateral margins; lateral zone with arched ventral rib; shallow posterolateral pit present on dorsal surface. Thoracic zone $1.75 \mathrm{~mm}$ wide. Fourth pedigerous somite incompletely divided from genital complex. Genital complex subcircular, $1.93 \times 1.85 \mathrm{~mm}$, slightly widened distally. Abdomen (Fig. 21B) fused with genital complex, nearly as long as wide, divided by lateral constriction into proximal $1 / 3$ and distal $2 / 3$. Caudal rami separated from each other by their width; each ramus $171 \times 146 \mu \mathrm{m}$, with 6 setae.

Antennule (Fig. 21C) 2-segmented; proximal segment with 25 pinnate and 2 naked setae; distal segment with 13 naked setae and 1 aesthetasc. Antenna (Fig. 21D) 3-segmented; first segment with large, distally tapering proximal process; second segment nearly quadrangular, with 1 dorsal and another small, inner distal adhesion pads; third segment forming large, distally strongly bent claw bearing 2 setae. Postantennal process (Fig. 21E) bearing 2 papillae each tipped with several setules; another papilla located posterior to postantennal process. Sclerotized process present near base of postantennal process (Fig. 23E).

Mandible (Fig. 21F) with 12 teeth distally. Maxillule (Fig. 21G) consisting of anterior papilla bearing 3 unequal setae and posterior process bearing 2 tines. Maxilla (Fig. 21H) 2-segmented; proximal segment (lacertus) unarmed, $750 \mu \mathrm{m}$ long; distal segment (brachium) with large membrane (flabellum) near middle; calamus about twice as long as canna; canna with 1 claw-like process near middle of inner (convex) margin (Fig. 21I). Maxilliped (Fig. 22A) 3-segmented; first segment (corpus) unarmed but with 2 patches of granules on inner side of distal half; second segment (shaft) short, with 1 distal seta; third segment forming large, sharp claw. Sternal furca (Fig. 22B) divergent, with spatulate tines.

Armature on rami of legs 1-4 as follows:

Leg 1: exopod 1-0; III,1,3; endopod (vestigial)

Leg 2: exopod I-1; I-1; II,I,5; endopod 0-1; 0-2; 6

Leg 3: exopod I-1; I-1; III,4; endopod 0-1; 6

Leg 4: exopod I-0; I-0; III; endopod (lacking)

Leg 1 (Fig. 22C) coxa with branched small outer setule; basis with pinnate outer and inner setae. Proximal exopodal segment bullate, with 1 small outer distal naked seta and row of setules on inner margin; two inner distal spines bifurcating subterminally, with membrane near base. Leg 2 (Fig. 22E) coxa with large seta on inner posterior margin and small tubercle and setule on ventral surface; basis with small outer seta and 1 inner setule and membrane on inner part of posterior margin. Leg 3 (Fig. 24G) exopod with first segment bearing 3 setules on outer margin. Leg 4(Fig. 23A) protopod almost straight, with nearly parallel lateral margins and small outer distal seta; first exopodal segment with very small distal seta ( $37 \mu \mathrm{m}$ long); second segment longest among exopodal segments, its distal spine $180 \mu \mathrm{m}$ long; 3 spines on third exopodal segment $175,210,440 \mu \mathrm{m}$, respectively, from outer to inner; all spines on exopodal segments accompanied with flabelliform membrane near base (Fig. 23B). Leg 5 (Fig. 23C) represented by small papilla tipped with 1 seta and plate bearing 3 setae on posterior margin of genital complex.

Male. Body (Fig. 23D) $3.55 \mathrm{~mm}$ long. Cephalic shield $2.33 \times 2.03 \mathrm{~mm}$, resembling that of female. Genital complex fused with fourth pedigerous somite and abdomen, but discernible by lateral constrictions, $630 \times 570 \mu \mathrm{m}$. Abdomen (Fig. 23E) $280 \times 330 \mu \mathrm{m}$, gradually widened distally. Caudal ramus $115 \times 145 \mu \mathrm{m}$.

Antennule armed with 29 setae on proximal segment; distal segment armed as in female. Antenna (Fig. 23F) with large adhesion pads on first and second segments; 

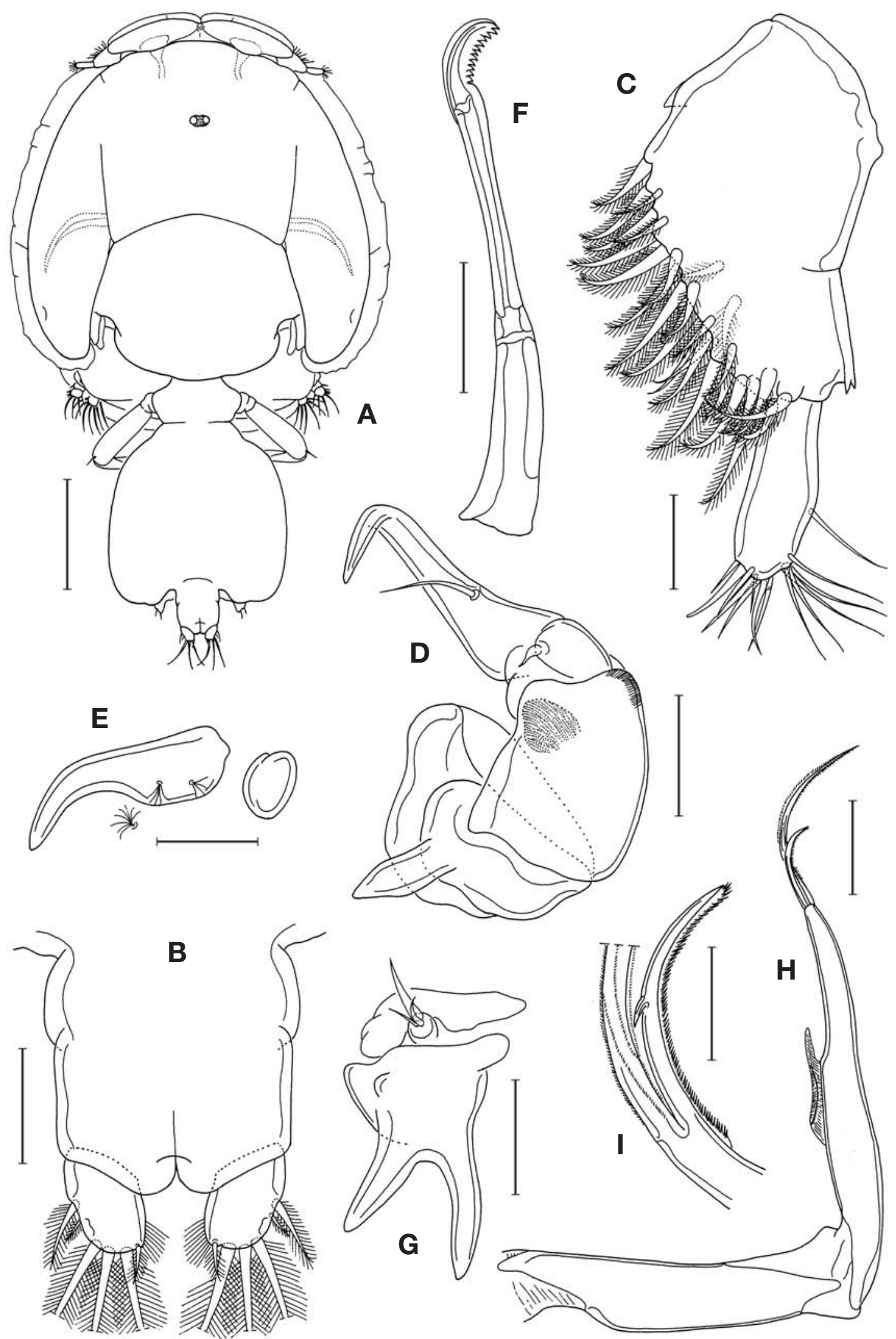

Fig. 21. Lepeophtheirus gusevi n. sp., female. A. habitus, dorsal. B. abdomen, dorsal. C. antennule. D. antenna. E. postantennal process. F. mandible. G. maxillule. H, I. maxilla. Scales=A. $1 \mathrm{~mm}$. B, D, E, G, H. $0.2 \mathrm{~mm}$. C, F, I. $0.1 \mathrm{~mm}$. 


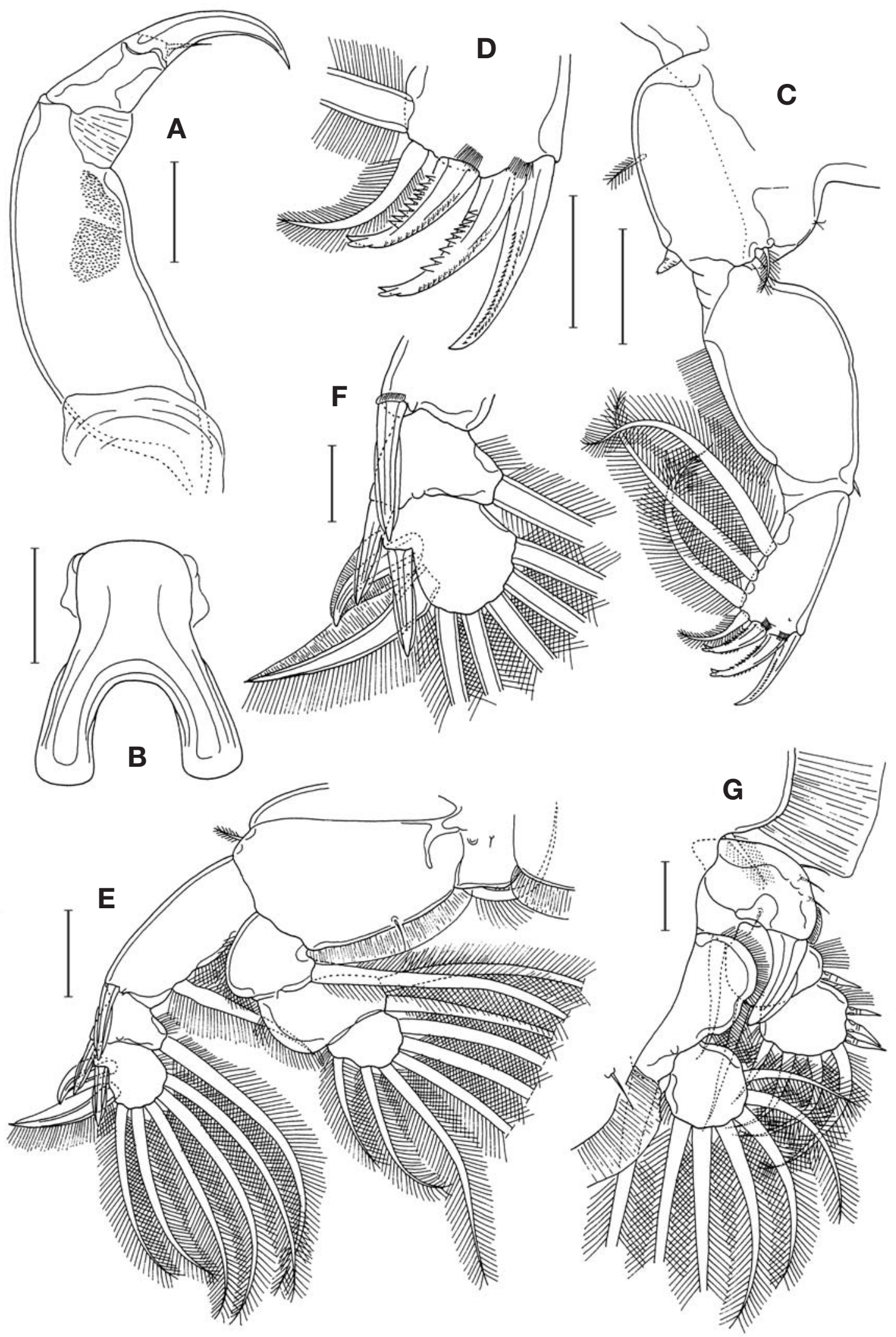

Fig. 22. Lepeophtheirus gusevi n. sp., female. A. maxilliped. B. sternal furca. C. leg 1. D. distal part of leg 1. E. leg 2. F. exopod of leg 2. G. leg 3. Scales=A-C, E. $0.2 \mathrm{~mm}$. D, F, G. $0.1 \mathrm{~mm}$. 

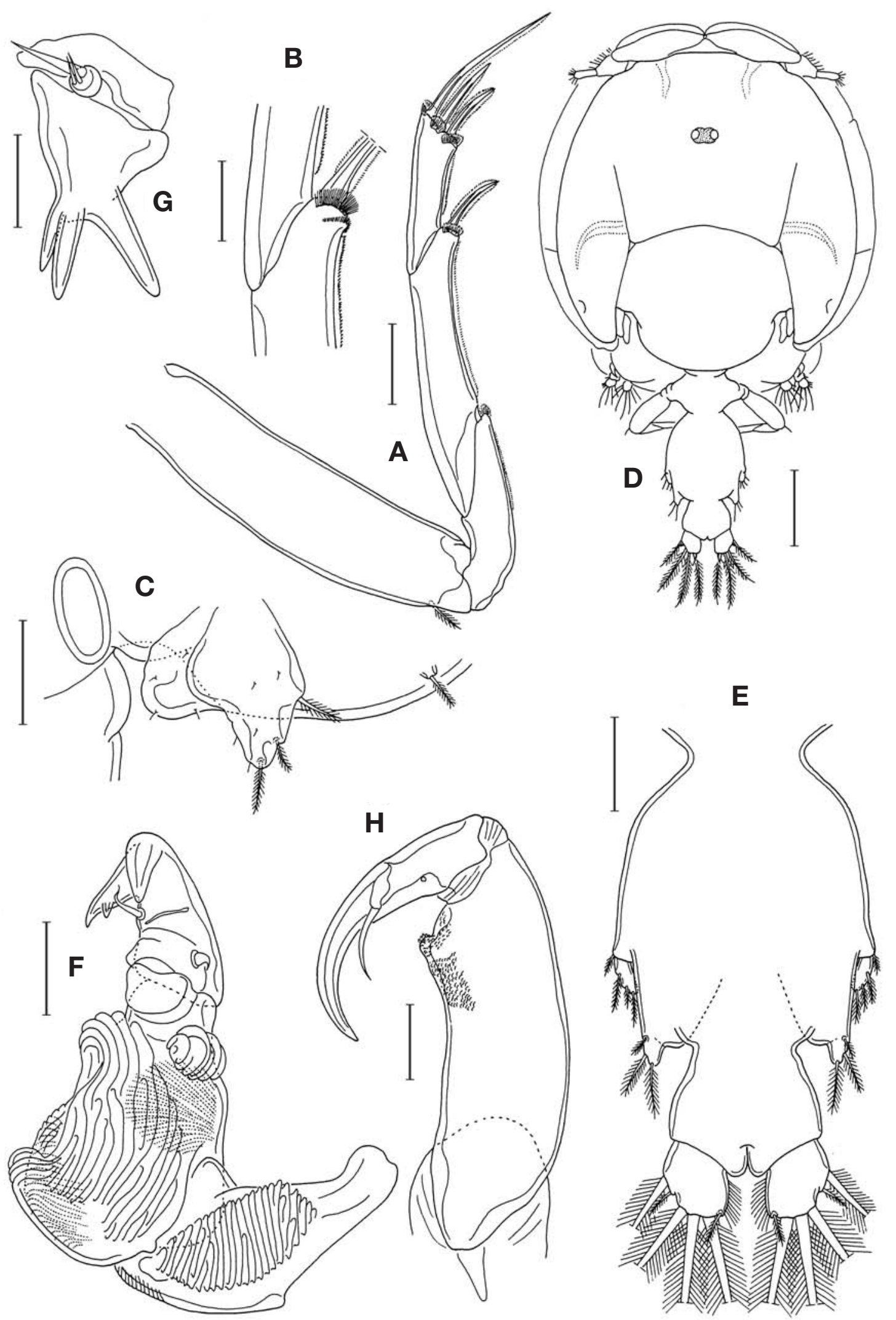

Fig. 23. Lepeophtheirus gusevi n. sp., female. A. leg 4. B. juction between second and third exopodal segment of leg 4. C. leg 5. Male. D. habitus, dorsal. E. genital somite and abdomen, dorsal. F. antenna. G. maxillule. H. maxilliped. Scales=A, C, E. $0.2 \mathrm{~mm}$. B, F-H. $0.1 \mathrm{~mm}$. D. $0.5 \mathrm{~mm}$. 
second segment strongly expanded proximally; third segment bearing 2 setae and 2 strong claws, one of latter with subsidiary claw. Second segment with 3 adhesion pads; third segment with 2 inner proximal setae and forming strongly curved, large claw (Fig. 23F). Postantennal process more slender than that of female.

Mandible and maxilla as in female. Maxillule (Fig. 23G) with 3 tines on posterior process. Maxilliped (Fig. 23H) with 1 small process subdistally on inner margin. Sternal furca as in female.

Legs 1-4 as in female. Leg 5 represented by 4 setae on lateral process (Fig. 23E). Leg 6 represented by 3 setae on posterior process of genital complex (Fig. 23E).

Etymology. The specific name gusevi is derived from the former Russian researcher A. V. Gusev who first reported this species as Lepeophtheirus sp.

Remarks. Gusev (1951) discovered only a single female of this species from Sebastes taczanowskii Steindachner in the Siberian coast and recorded it as Lepeophtheirus $\mathrm{sp}$. His illustrations for the habitus, caudal rami, sternal furca, posterior tines of maxilla, and leg 5 are generally similar to those of our specimens.

Lepeophtheirus gusevi n. sp. bears the following key characters: 1) the exopod of leg 4 is 3 -segmented, with armature formula I-0; I-0; III; 2) the maxillule of female bears 2 distal tines; 3 ) the female abdomen is single-segmented and slightly wider than long; and 4) the tines of the sternal furca are spatulate, with truncate distal margin. The above characters of $L$. gusevi are shared by five congerners, L. hummi Pearse, 1952, L. longicaudus Cressey, 1966, L. paralichthydis Yamaguti and Yamasu, 1960, L. spatha Dojiri and Brantley, 1991, and L. uluus (Lewis, 1964). These congeners may be distinguished from $L$. gusevi by their features as follows.

In $L$. hummi and $L$. spatha, the tines of the female sternal furca greatly expanded distally, almost ax-like, and the terminal segment of the male antenna is simple, forming a claw. In L. longicaudus, the caudal ramus is elongated, about four times as long as wide, and the postantennary process is unusual in shape. In L. paralichthydis the caudal ramus is very small and wider than long, the abdomen is tapering, and the proximal process of the female antenna and the tines of the maxillule are spatulate. In L. uluus leg 5 of the female is elongated, extending much beyond the caudal ramus.

Genus Anuretes Heller, 1865

\section{Anuretes quadrilaterus Shiino, 1954}

(Figs. 24-26)

Anuretes quadrilaterus Shiino, 1954, p. 264, figs. 3-5; Ho and Lin, 2003b, p. 300, figs. 1, 2; Ho and Lin, 2004, p. 98 , figs. 49,50 .
Material examined. 1 우, $1 \sigma^{7}$ from the gill chambers of Zenopsis nebulosa (Temminck and Schlegel), at Yangpo Port, Pohang-shi, Gyeongsangbuk-do, I.-H. Kim, 21 November 2009.

Female. Body (Fig. 24A) $5.65 \mathrm{~mm}$ long. Cephalothoracic shield nearly circular, $3.75 \times 3.85 \mathrm{~mm}$; ventral rib of lateral zone L-shaped, abruptly bent distally; posterior margin of thoracic zone concave; posterolateral pit absent. Fourth pedigerous somite short and concealed by thoracic zone of cephalothoracic shield. Genital complex $1.86 \times$ $2.17 \mathrm{~mm}$, wider than long, with rounded corners. Abdomen small, wider than long (Fig. 24B), fused with genital complex, $298 \mu \mathrm{m}$ wide, 1-segmented, its proximal onethird slightly wider than distal two-thirds. Caudal rami (Fig. 24B) remotely separated from each other and divergent; each ramus $158 \times 115 \mu \mathrm{m}$, distinctly broadened distally, with 6 setae.

Antennule 2-segmented; proximal segment with 27 setae (25 pinnate and 2 naked); distal segment elongated, much longer than proximal segment, with 12 naked setae and 2 aesthetascs. Antenna 3-segmented; first segment with small proximal process (Fig. 24C); second segment nearly quadrangular; third segment forming large, robust claw bearing 2 small setae. Postantennal process short, with 2 papillae tipped with setules; another papilla located posterior to postantennal process tipped with 4 setules.

Mandible with 12 teeth distally. Maxillule consisting of anterior papilla bearing 3 small setae and posterior process bearing strongly tapering distal tine (Fig. 24C). Maxilla (Fig. 24D) slender and 2-segmented; proximal segment (lacertus) unarmed, with parallel lateral margins; distal segment (brachium) gradually narrowed distally, with rudimentary flabellum in middle of inner margin; calamus $354 \mu \mathrm{m}$ long and canna $150 \mu \mathrm{m}$ long. Maxilliped (Fig. 24E) 3-segmented; first segment (corpus) stout, with 1 weak process on inner margin; second segment (shaft) short, with 1 distal seta; third segment almost fused with second, forming stout claw. Sternal furca (Fig. 24F) with blunt, slightly divergent distal tines bearing hyaline flange on inner margin.

Armature on rami of legs 1-4 as follows:

Leg 1: exopod 1-0; III,1,3; endopod 3

Leg 2: exopod I-1; I-1; II,I,5; endopod 0-1; 0-2; 6

Leg 3: exopod I-1; III,I,5; endopod 0-0; 6 (or 5)

Leg 4: exopod I-0; III; endopod (lacking)

Leg 1 (Fig. 24G) basis with pinnate outer and inner setae. Proximal exopodal segment with 1 small outer distal naked seta and row of setules on distal part of inner margin; distal segment widened distally; two inner distal spines bifurcating at their midlength; distal seta small, not longer than distal spines (Fig. 24H); endopod small and tipped by 3 setae (or processes). Leg 2 (Fig. 25A) coxa with large seta on inner posterior margin and $1 \mathrm{mi}-$ 


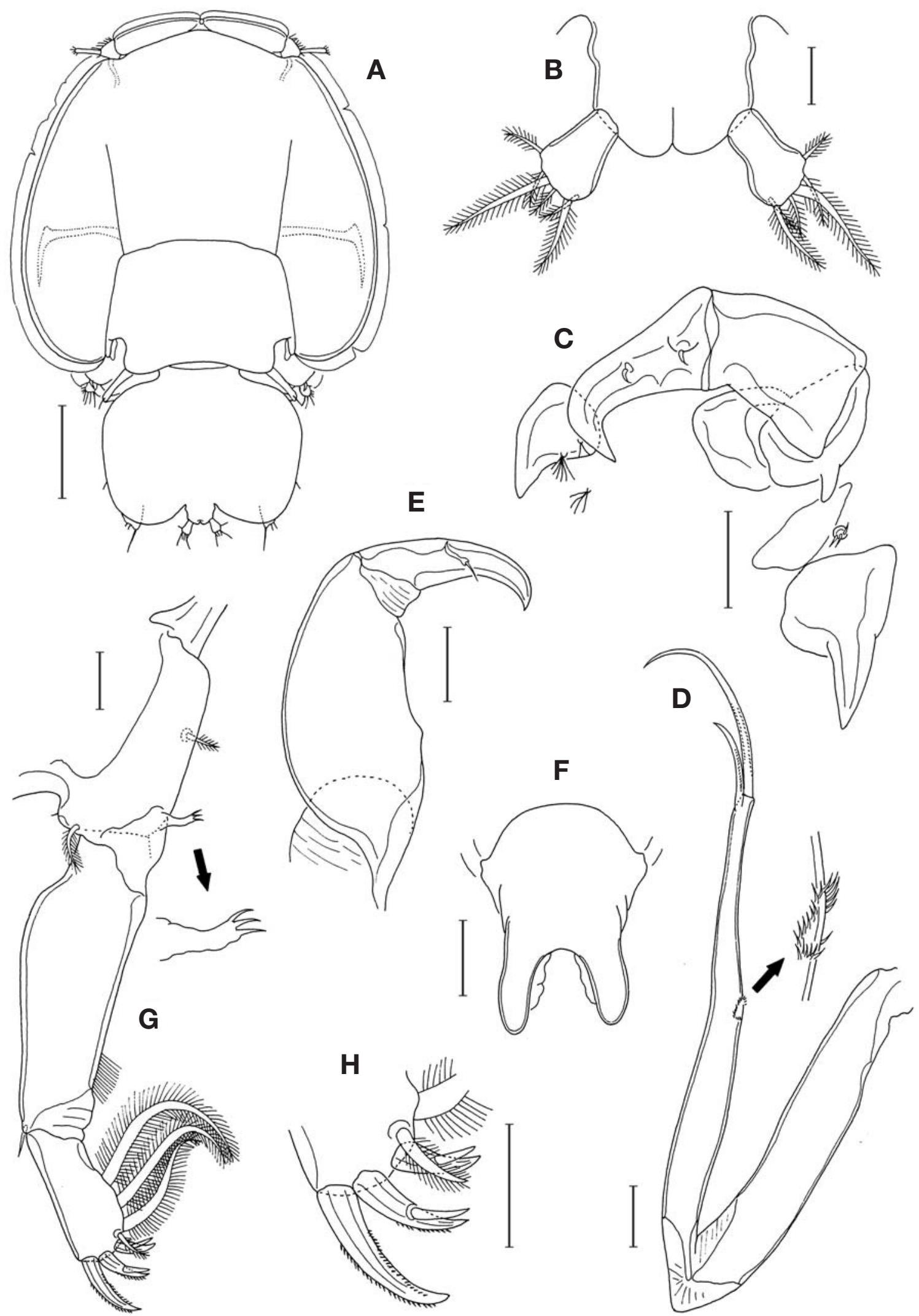

Fig. 24. Anuretes quadrilaterus Shiino, female. A. habitus, dorsal. B. abdomen, ventral. C. antenna, postantennal process, and maxillule. D. maxilla. E. maxilliped. F. sternal furca. G. leg 1. H. distal part of leg 1. Scales=A. $1 \mathrm{~mm}$. B, D, F-H. $0.1 \mathrm{~mm}$. C, E. $0.2 \mathrm{~mm}$. 


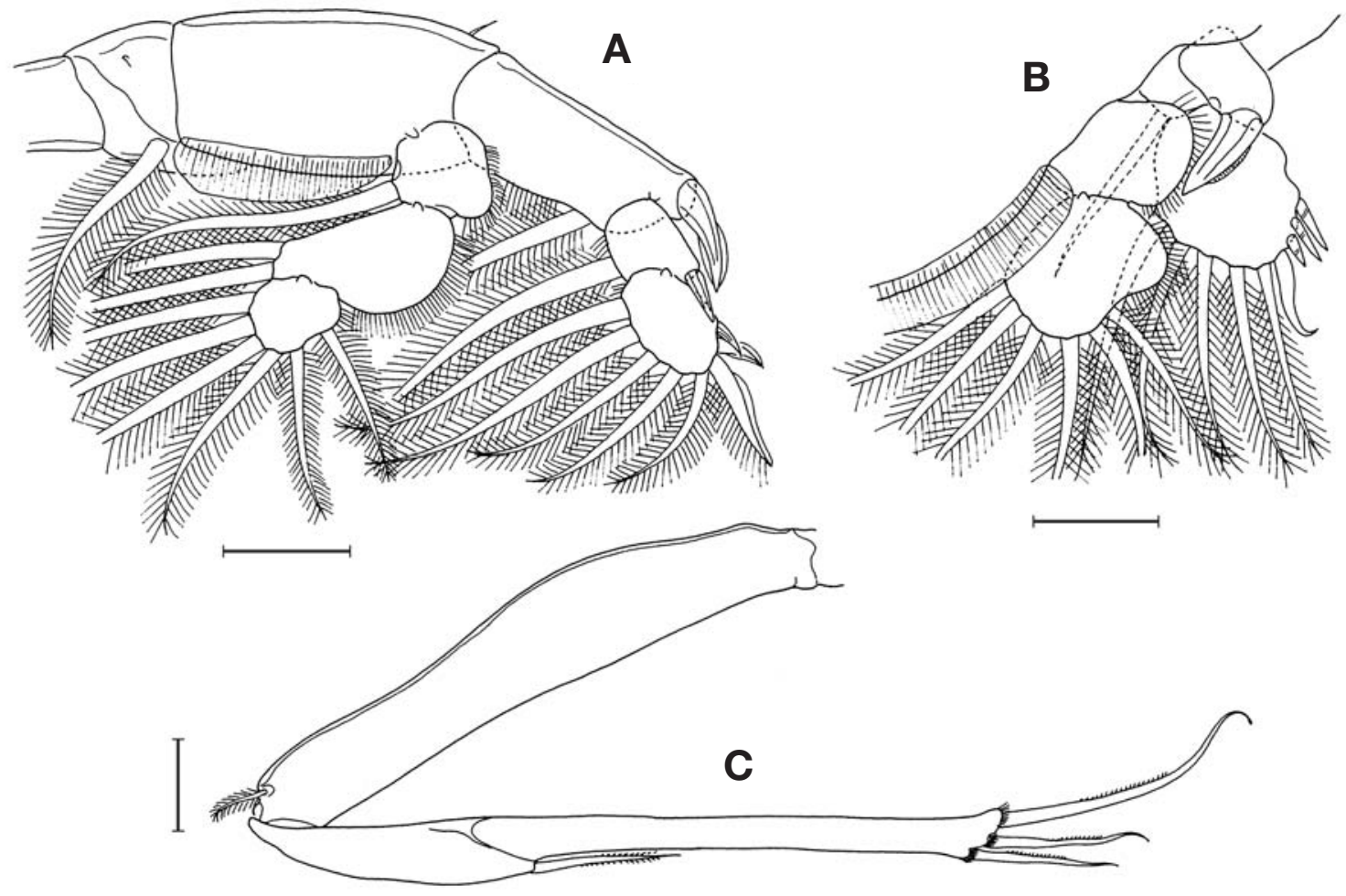

Fig. 25. Anuretes quadrilaterus Shiino, female. A. leg 2. B. leg 3. C. leg 4. Scales=A. $0.2 \mathrm{~mm}$. B, C. $0.1 \mathrm{~mm}$.

nute setule on ventral surface; basis with small outer seta. Leg 3 (Fig. 25B) with 2-segmented rami; distal endopodal segment with 5 or 6 setae. Leg 4 (Fig. 25C) protopod slightly expanded at proximal third; distal exopodal segment much longer and slender than proximal segment. Leg 5 represented by 1 small setae on lateral margin of genital complex and small plate bearing 3 small setae on posterolateral margin of genital complex (Fig. 24A).

Male. Body (Fig. 26A) with large cephalothoracic shield and small urosome, $2.94 \mathrm{~mm}$ long. Cephalic shield resembling that of female. Genital complex strongly tapering (Fig. 26B), $0.79 \times 1.09 \mathrm{~mm}$. Abdomen small, much wider than long and 1-segmented. Caudal ramus $89 \times 90 \mu \mathrm{m}$.

Antennule (Fig. 26C) armed as in female, but distal segment relatively longer than that of female. Antenna (Fig. 26D) 3-segmented as in female; first segment unarmed; second segment with several weakly developed adhesion pads; third segment with 2 inner proximal setae and short bifurcate distal claw. Postantennal process as in female.

Mandible and maxilla as in female. Maxillule (Fig. 26E) with narrow distal tine bearing corrugation and 1 small seta. Maxilliped (Fig. 26F) with more prominent process on inner margin of first segment. Sternal furca with narrower and distinctly divergent tines.

Legs 1-4 as in female. Leg 5 similar to that of female (Fig. 26G). Leg 6 represented by 3 posterior setae on genital complex (Fig. 26G).
Distribution and host. Only from Zenopsis nebulosa (Temminck and Schlegel) in Japan (Shiino, 1954), Taiwan (Ho and Lin, 2003b), and Korea (present study).

Remarks. This is the third record of occurrence for $A$. quadrilaterus Shiino, 1954, following the original (Shiino, 1954) and Ho and Lin's (2003b) records. From both Japan and Taiwan, the host was Zenopsis nebulosa and hence this species is considered as host-specific to Z. nebulosa. Shiino (1954) observed only five setae on the lateral margin of the male genital complex, a difference from our observation that the margin carries seven setae consisting of the anterior $1+3$ setae as leg 5 and the posterior 3 setae as leg 6 .

\section{Genus Pseudanuretes Yamaguti, 1936}

\section{Pseudanuretes chaetodontis Yamaguti, 1936}

(Figs. 27-29)

Pseudanuretes chaetodontis Yamaguti, 1936, p. 16, pl. 12, figs. 186-196; Kabata, 1965, p. 25, fig. 4D.

Material examined. More than 300 우 우 and 100 이 $\sigma^{7}$ from gills of 4 Chaetodontoplus septentrionalis (Temminck and Schlegel), at Gosan, Jeju Island, M.-K. Choe, 25 June 2009.

Female. Body (Fig. 27A) small, $0.99 \mathrm{~mm}$ long. Cephalothoracic shield $675 \times 585 \mu \mathrm{m}$, with thin membrane along 

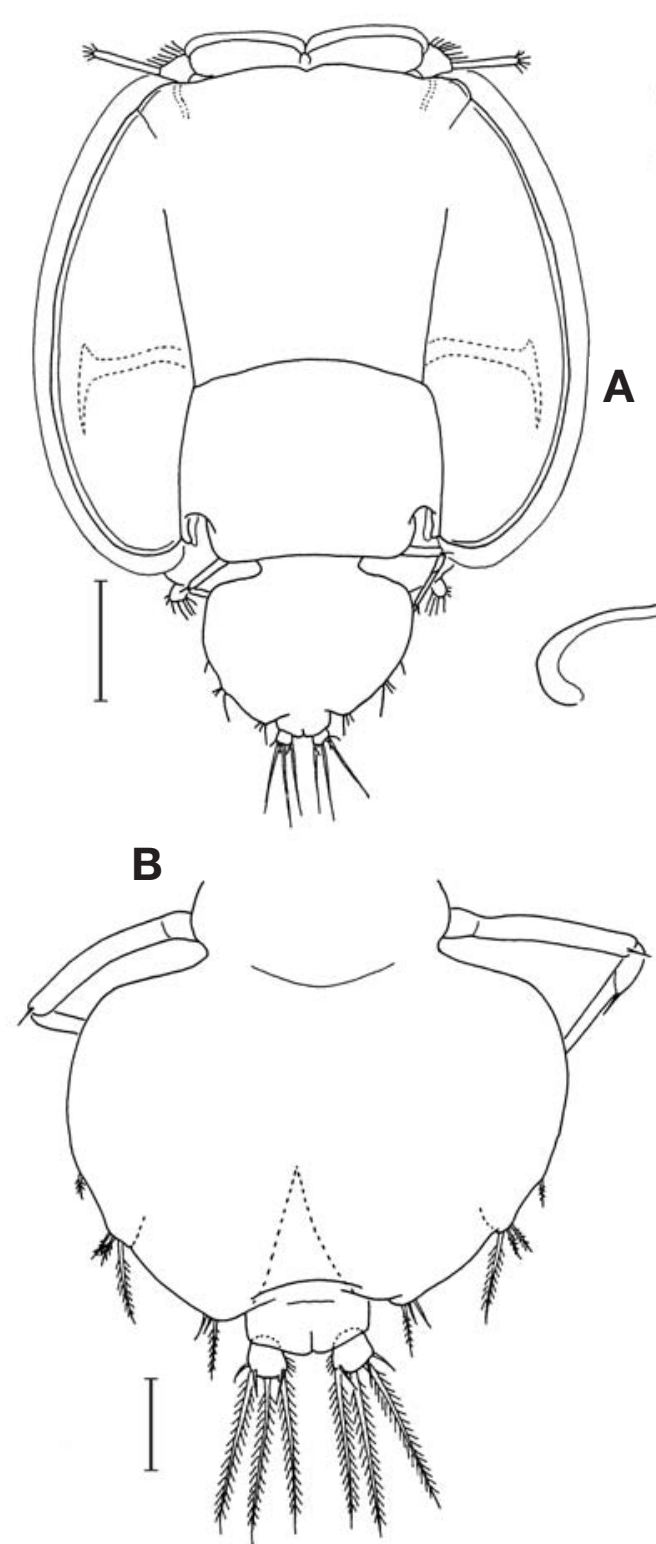

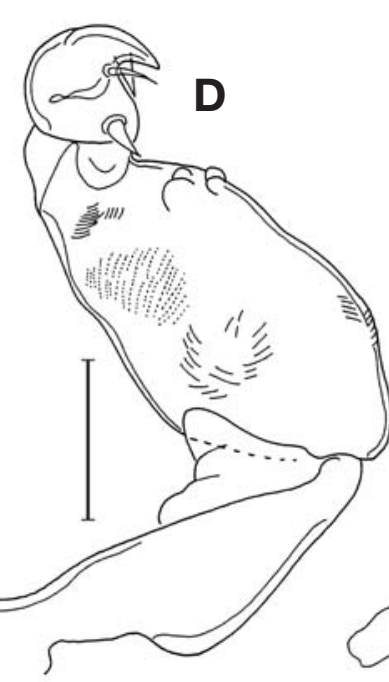

Nos

E

I
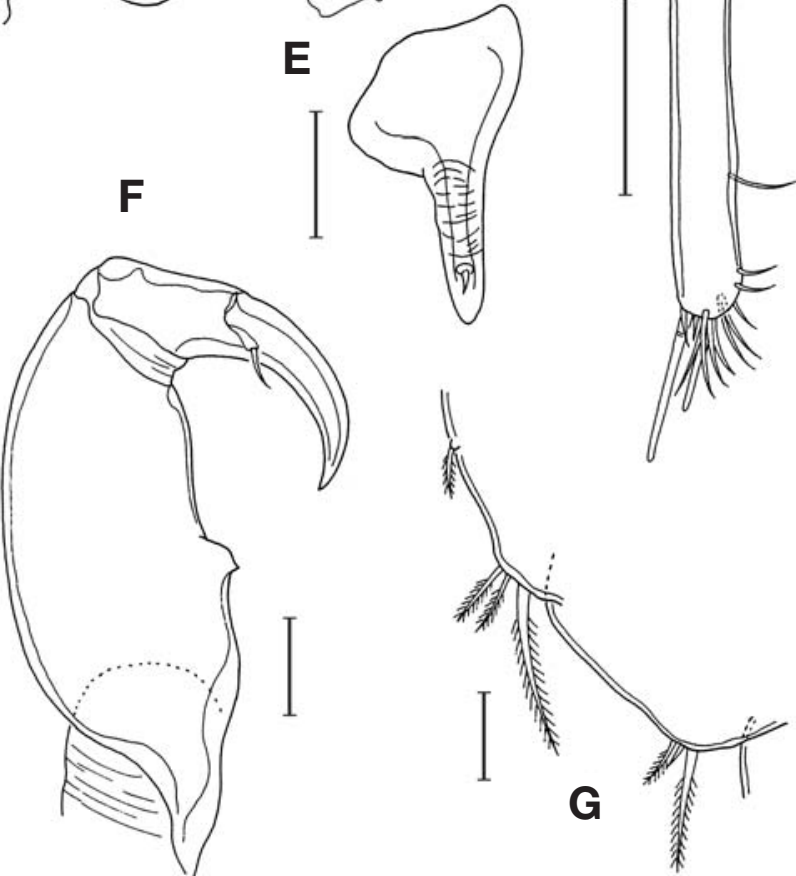

Fig. 26. Anuretes quadrilaterus Shiino, male. A. habitus, dorsal. B. urosome, dorsal. C. antennule. D. antenna. E. maxillule. F. maxilliped. G. legs 5 and 6. Scales=A. $0.5 \mathrm{~mm}$. B. $0.2 \mathrm{~mm}$. C-G. $0.1 \mathrm{~mm}$.

lateral margins. Cephalic zone with 1 pair of setules and other minute setules on dorsal surface. Ventral rib of lateral zone almost straight but its distal end slightly curved; posterior sinus absent; thoracic zone nearly rectangular, its posterior margin straight but with small process in middle. Fourth pedigerous somite not visible in dorsal view of body. Genital complex $311 \times 456 \mu \mathrm{m}$, narrower distally, with posteromedian cleft. Abdomen absent. Caudal ramus (Fig. 27C) very small, $19 \times 17 \mu \mathrm{m}$, with only 5 setae, one of them distinctly larger than others. Egg sac containing maximum of 3 eggs.

Antennule (Fig. 27D) $237 \mu \mathrm{m}$ long and 2-segmented; proximal segment tapering, with curved, irregularly shaped setae (hardly countable); distal segment slender and curved, with 13 setae and 2 aesthetascs. Antenna (Fig. 27E) 3-segmented; first segment with elongate proximal process; second segment nearly ovoid and unarmed; third segment forming long, distally strongly bent claw bearing 1 seta and 1 claw-like process. Postantennal process (Fig. 29F) rudimentary, with 3 papillae each tipped with 1 or 2 setules.

Mandible not examined. Maxillule consisting only of papilla bearing 2 unequal setae (Fig. 27B); posterior process absent (Fig. 27E). Maxilla (Fig. 27G) 2-segmented; 


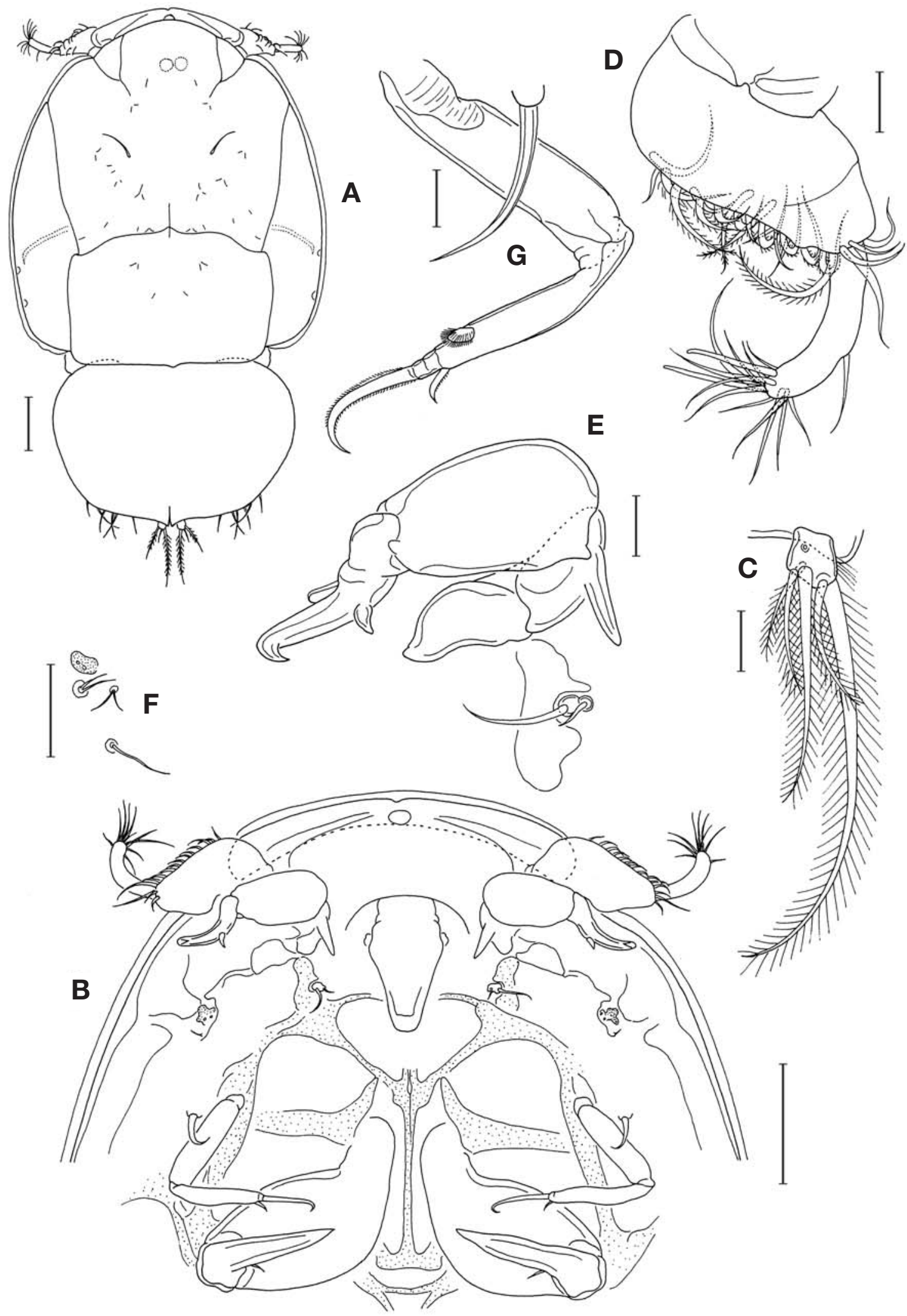

Fig. 27. Pseudanuretes chaetodontis Yamaguti, female. A. habitus, dorsal. B. cephalic area, ventral. C. caudal ramus, ventral. D. antennule. E. antenna and maxillule. F. postantennal process. G. maxilla and maxillary whip. Scales=A, B. $0.1 \mathrm{~mm}$. C-G. $0.02 \mathrm{~mm}$. 

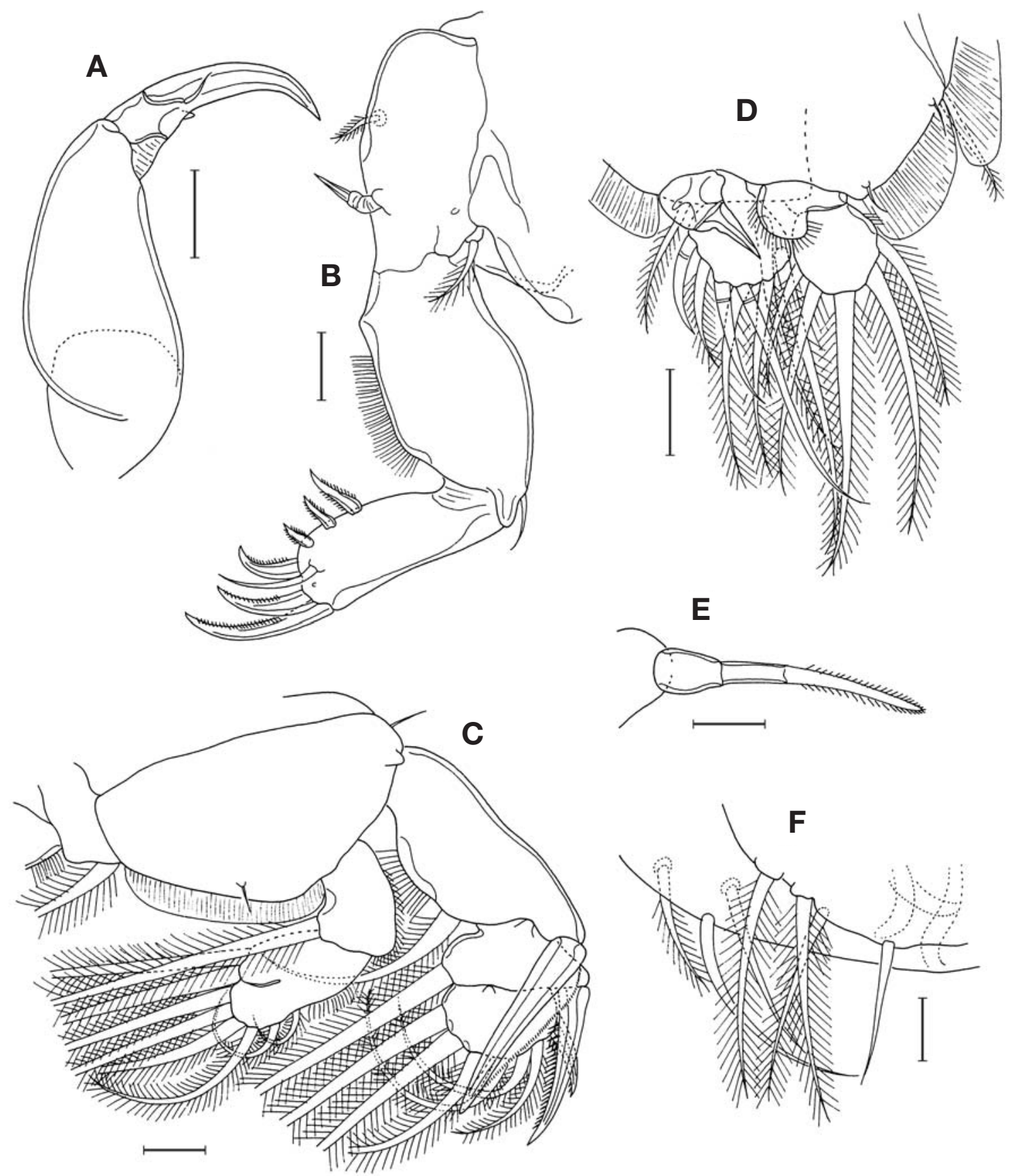

Fig. 28. Pseudanuretes chaetodontis Yamaguti, female. A. maxilliped. B. leg 1. C. leg 2. D. leg 3. E. leg 4. F. legs 5 and 6. Scales=A. 0.05 mm. B-F. $0.02 \mathrm{~mm}$.

proximal segment (lacertus) unarmed; distal segment (brachium) with subdistal flabellum on inner margin; canna much smaller than calamus and located subdistally. Large maxillary whip present nearby maxilla (Fig. 27B, G). Maxilliped (Fig. 28A) 3-segmented; first segment (corpus) gradually narrowed distally, with smooth lateral margins; second segment (shaft) short, distally with 1 seta and 1 small tubercle; third segment almost fused with second, forming strong claw. Sternal furca absent.

Armature on rami of legs 1-4 as follows:

Leg 1: exopod 1-0; III,1,3; endopod (vestigial)

Leg 2: exopod I-1; I-1; I,6; endopod 0-1; 8

Leg 3: exopod I-0; 8; endopod 0-0; 5

Leg 4: exopod I; endopod (lacking)

Leg 1 (Fig. 28B) basis with pinnate outer and inner se- 

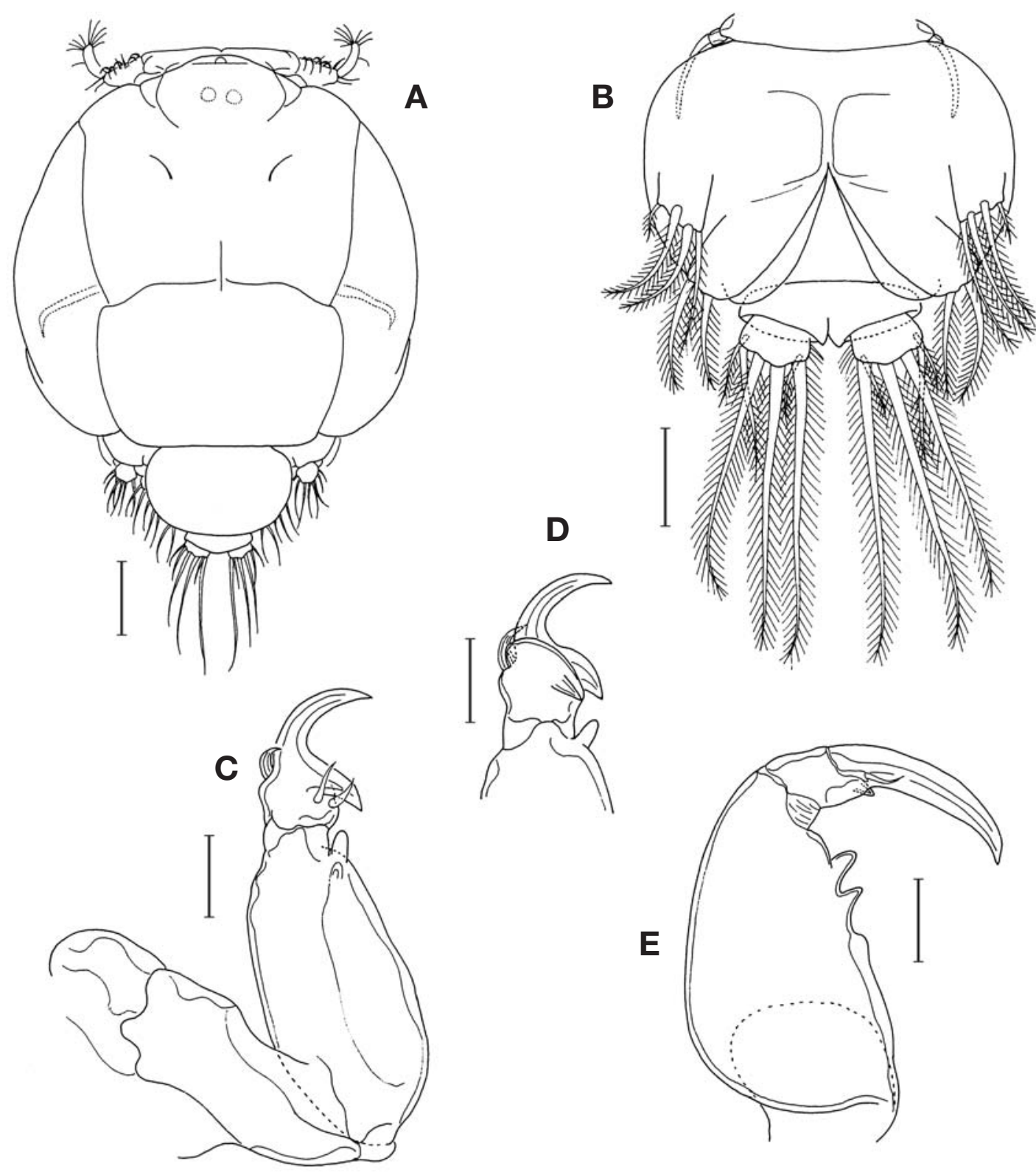

Fig. 29. Pseudanuretes chaetodontis Yamaguti, male. A. habitus, dorsal. B. urosome, ventral. C. antenna. D. terminal segment of antenna. E. maxilliped. Scales=A. $0.1 \mathrm{~mm}$. B, E. $0.05 \mathrm{~mm}$. C, D. $0.02 \mathrm{~mm}$.

tae. Proximal exopodal segment broad, with 1 outer distal naked seta and row of setules on inner margin; distal segment broader distally than proximally; three distal spines gradually larger from outer to inner, not bifurcate; 3 inner setae short and spiniform. Leg 2 (Fig. 28C) coxa with large seta on inner posterior margin; basis with small outer seta and 1 inner setule and membrane on inner part of posterior margin; first and second exopodal segments each with large outer spine extended far beyond end of exopod; second endopodal segment with rudiment of segmentation. Leg 3 (Fig. 28D) with 2-segmented rami; spine on first exopodal segment tapering and pointed; some of setae on second exopodal segment naked; first endopodal segment unarmed. Leg 4 (Fig. 28E) represented by 1 segment $(19 \times 12 \mu \mathrm{m})$ tipped by 1 spine $(58 \mu \mathrm{m})$. Legs 5 and 6 (Fig. 28F) probably represented by 3 and 4 setae, respectively.

Male. Body (Fig. 29A) $715 \mu \mathrm{m}$ long. Cephalic shield resembling that of female. Urosome (Fig. 29B) small. Genital complex ovoid, $132 \times 202 \mu \mathrm{m}$. Abdomen short, much wider than long. Caudal ramus also much wider than long, $23 \times 37 \mu \mathrm{m}$. 
Antennule as in female. Antenna (Fig. 29C) 3-segmented as in female; first segment unarmed; second segment with 2 small digitiform process distally; third segment bearing 2 proximal setae (Fig. 29C) and 4 claws (2 of them larger and remaining 2 small) (Fig. 29D). Postantennal process as in female.

Maxillule and maxilla as in female. Maxilliped (Fig. 29E) with 2 prominent, digitiform process on inner margin of first segment.

Legs 1-4 as in female. Leg 5 represented by ventrolateral lobe tipped by 4 setae (Fig. 29B). Leg 6 represented by 2 setae on posterior end of genital flap (Fig. 29B).

Distribution and hosts. From Chaetodon sp. in Japan (Yamaguti, 1936), Chaetodontoplus personifer (McCulloch) in Australia (Kabata, 1965), and Chaetodontoplus septentrionalis (Temminck and Schlegel) in Korea (present study).

Remarks. We found more than a hundred specimens of this parasite on each individual of the host fish C. septentrionalis. This high prevalence contrasts to the previous observations of only six females by Kabata (1965) in Australia and ten females by Yamaguti(1936) in Japan.

\section{ACKNOWLedgements}

This study was carried out as a part of the project "The Discovery of Korean Indigenous Species" supported by the National Institute of Biological Resources (NIBR), Korea.

\section{REFERENCES}

Choe, M.-K. and I.-H. Kim. 2010. Redescriptions of two morphologically confusing sea lice Caligus aesopus Wilson, 1921 and C. spinosus Yamaguti, 1939 (Copepoda: Siphonostomatoida: Caligidae) parasitic on amberjacks (Seriola spp.) from Korea. Zootaxa 2493:23-34.

Fernández, J. and C. Villalba. 1986. Contribution to the knowledge of the genus Caligus Müller, 1785 (Copepoda: Siphonostomatoida) in Chile. Gayana, Zool. 50(1-4):37-62.

Gnanamuthu, C.P. 1950. Three new copepod parasites of the ribbon fish from South India. J. Parasitol. 38(2):113-119.

Gusev, A.V. 1951. Parazitcheskie Copepoda s nekotorykh morskikh ryb. Parasit. Sb. 13:394-463 (in Russian).

Hewitt, G.C. 1971. Two species of Caligus (Copepoda, Caligidae) from Australian waters, with a description of some developmental stages. Pac. Sci. 25(2):145-164.

Ho, J.-s. and A.K.M. Bashirullah. 1977. Two species of caligid coepods (Crustacea) parasitic on marine fishes of Venezuela, with discussion of Metacaligus Thomsen, 1949. J. Nat. Hist. 11:703-714.

Ho, J.-s. and C.-L. Lin. 2002. New species of Metacaligus
(Caligidae, Copepoda) parasitic on the cutlassfish (Trichiurus lepturus) of Taiwan, with a cladistic analysis of the family Caligidae. Zool. Sci. 19:1363-1375.

Ho, J.-s. and C.-L. Lin. 2003a. Three species of Caligus (Copepoda: Caligidae) parasitic on fishes of the northeast coast of Taiwan. J. Fish. Soc. Taiwan 30(1):55-70.

Ho, J.-s. and C.-L. Lin. 2003b. Three species of sea lice (Copepoda: Caligidae) parasitic on marine fishes of Taiwan. J. Fish. Soc. Taiwan 30(4):299-314.

Ho, J.-s. and C.-L. Lin. 2004. Sea Lice of Taiwan (Copepoda: Siphonostomatoida: Caligidae). The Sueichan Press, Keelung, Taiwan, $387 \mathrm{pp}$.

Ho, J.-s., C.-L. Lin and S.-N. Chen. 2000. Species of Caligus Muller, 1785 (Copepoda: Caligidae) parasitic on marine fishes of Taiwan. Syst. Parasitol. 46:159-179.

Ho, J.-s., S.-H. Cheng, W.-C. Chang and C.-L. Lin. 2008. Two species of Siphonostomatoid copepods parasitic on marine fishes of Taiwan, J. Fish. Soc. Taiwan 35(1):8799.

Ho, J.-s., I.-H. Kim, E. R. Cruz-Lacierda and K. Nagasawa. 2004. Sea lice (Copepoda, Caligidae) parasitic on marine cultured and wild fishes of the Philippines. J. Fish. Soc. Taiwan 31(4):235-249.

Kabata, Z. 1965. Copepoda parasitic on Australian fishes. III. Genera Dentigryps, Henniochophilus and Pseudanuretes (Caligidae). Ann. Mag. Nat. Hist. 13(8):19-31.

Kabata, Z. 1979. Parasitic Copepoda of British Fishes. Ray Society, London, pp. 1-468, figs. 1-2031.

Kim, I.-H. 1998. Illustrated Encyclopedia of Fauna and Flora of Korea, 38. Cirripedia, Symbiotic Copepoda, Pycnogomida. Ministry of Education, Korea, 1038 pp.

Kim, I.-H. 2008. Invertebrate fauna of Korea, Vol. 21, No. 1, Sea Lice. Flora and Fauna of Korea Series, National Institute of Biological Resources, 66 pp.

Kirtisinghe, P. 1964. A review of the parasitic copepods of fish recorded from Ceylon with descriptions of additional forms. Bull. Fish. Rs. Sta., Dept. Fish. Ceylon 17:45-132.

Lewis, A.G. 1968. Copepod crustaceans parasitic on fishes of Eniwetok Atoll. Proc. U. S. Nat. Mus. 125:1-78.

Lin, C.-L. and J.-s. Ho. 2000. Four species of unrecorded caligid copepods (Siphonostomatoida) parasitic on marine fishes of Taiwan. J. Fish. Soc. Taiwan 27(3):201-224.

Lin, C.-L., J.-s. Ho and S.-N. Chen. 1994. Two species of Caligus (Copepoda: Caligidae) parasitic on black sea bream (Acanthopagrus schlegeli) cultured in Taiwan. Fish Pathol. 29:253-264.

Lin, C.-L., J.-s. Ho and S.-N. Chen. 1996. Two species of Caligidae (Copepoda) parasitic on cultured rabbit fish (Siganus fuscescens) in Taiwan. Fish Pathol. 31(3):129139.

Nordmann, A. von. 1832. Mikrographische Beitrage zur Naturgeschichte der wirbellosen Thiere 2:1-150.

Parker, R.R. 1969. Validity of the binomen Caligus elongatus for a common parasitic copepod formerly misidentified 
with Caligus rapax. J. Fish. Res. Bd. Can. 26(4):10131035.

Pillai, N.K. 1961. Copepods parasitic on South Indian Fishes. Pt. 1. Caligidae. Bull. Centr. Inst. Univ. Kerala 8:87-130.

Pillai, N.K. 1966. Notes on copepods parasitic on South Indian marine fishes. J. Mar. biol. Ass. India 8(1):123-140.

Pillai, N.K. and P. Natarajan. 1977. Copepods parasitic on fishes of the Kerala coast. Aquatic Biol. 2:19-43.

Rangnekar, M.P. 1959. Parasitic copepods from fishes of the western coast of India with description of one new species and redescription of four known species. J. Univ. Bombay B28(3):43-58.

Shiino, S.M. 1952. Copepods parasitic on Japanese fishes. 1. On the species of Caligus and Lepeophtheirus. Rep. Fac. Fish. prefect. Univ. Mie 1(1):79-113.

Shiino, S.M. 1954. Copepods parasitic on Japanese fishes. 3. One two new species of the genus Anuretes. Rep. Fac. Fish. prefect. Univ. Mie 1(3):260-271.

Shiino, S.M. 1960. Copepods parasitic on fishes collected on the coast of Province Shima, Japan. Rep. Fac. Fish. prefect. Univ. Mie 3:471-500.

Shiino, S.M. 1964. Results of Amami Expedition. Rep. Fac. Fish. prefect. Univ. Mie 5(1):243-255.
Thomsen, R. 1949. Copépodos parásitos de los peces marinos del Uruguay. Co. Zool. Mus. Hist. nat. Mont. 3:1-41.

Yamaguti, S. 1936. Parasitic copepods from fishes of Japan, Pt. 2. Caligoida, I. Published by the author, pp. 1-22, pls. 1-12.

Yü, S.C. 1933. Chinese parasitic copepods collected by H.W. Wu, with descriptions of new genera and species. Bull. Fan Mem. Inst. Biol. 4(4):117-139, pls. 1-8.

Venmathi Maran, B.A. and S. Ohtsuka. 2008. Descriptions of caligiform copepods in plankton samples collected from East Asia: Accidental occurrences or a new mode of life cycle? Plankton and Benthos Res. 3:202-215.

Venmathi Maran, B.A., T.S. Leong, S. Ohtsuka and K. Nagasawa. 2009. Records of Caligus (Crustacea: Copepoda: Caligidae) from marine fish cultured in floating cages in Malaysia with a redescription of male Caligus longipedis Bassett-Smith, 1898. Zool. Stud. 48:797-807.

Venmathi Maran, B.A., S-Y. Oh, H.Y. Soh, H.J. Choi and JG. Myoung. 2012. Caligus sclerotinosus (Copepoda: Caligidae), a serious pest of cultured red seabream Pagrus major(Sparidae) in Korea. Vet. Parasitol. 188:355-361.

Submitted: July 26, 2012, Accepted: August 24, 2012 